\title{
Jelaware River Water Quality
}

2ristol to Marcus Hook

\section{?ennsylvania}

\section{August 1949 to December 1963}

$\because$ W. B. KEIGHTON

ONTRIBUTIONS TO THE HYDROLOGY OF THE UNITED STATES

E ELOGICAL SURVEY WATER-SUPPLY PAPER 1809-O

Prepared in cooperation with the rity of Philadelphia 


\section{UNITED STATES DEPARTMENT OF THE INTERIOR}

\section{STEWART L. UDALL, Secretary}

\section{GEOLOGICAL SURVEY}

Thomas B. Nolan, Director 


\section{CONTENTS}

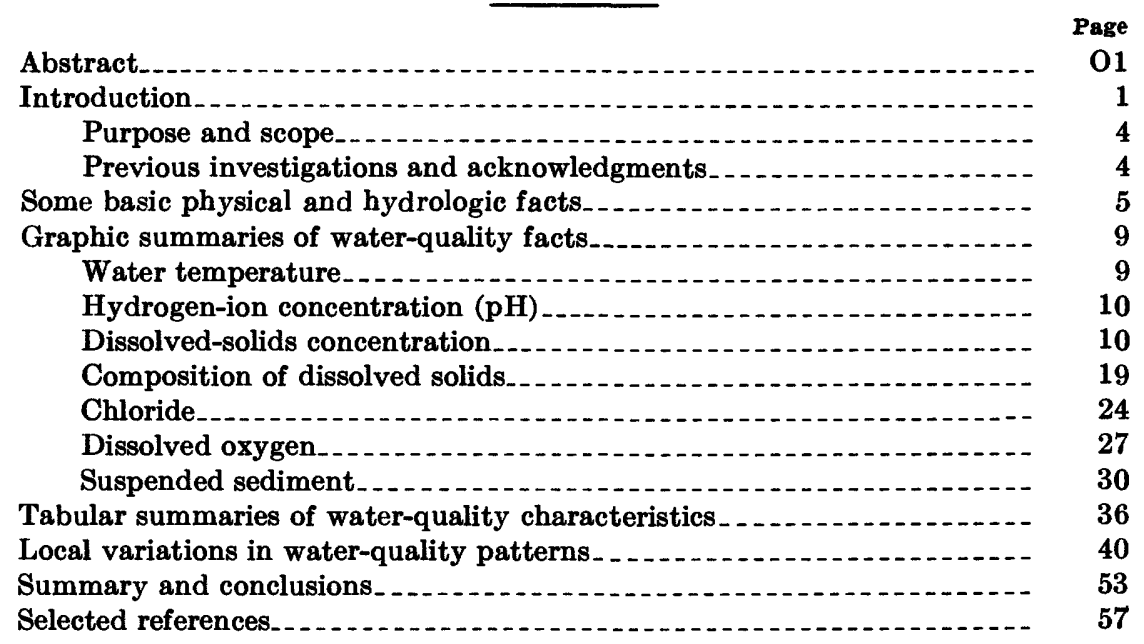

\section{ILLUSTRATIONS}

Fradre 1. Map showing location of sampling stations

Page

03

2-29. Graphs showing:

2. Annual water discharge of the Delaware River at Trenton, N.J. ........

3. Monthly water discharge of the Delaware River at Trenton, N.J.

4. Annual water temperature.......... 10

5. Frequency of water temperatures.

6. Distribution of water temperatures each month-- 12

7. Annual pH values of water........ 14

8. Frequency of $\mathrm{pH}$ values.

9. Relation between electrieal conductivity and dissolved solids $(0-200 \mathrm{ppm}) \ldots$

10. Relation between electrical conductivity and dissolved solids (200-4,000 ppm)

11. Annual mean conductivities..... 18

12. Annual maximum conductivities._._._._._. 19

13. Frequency of dissolved-solids concentrations_-_-_ 20

14. Monthly mean conductivities and water discharge, 1954

15. Mean monthly conductivities. 22 
FIGURE 1. 16. Relation between concentration and composition of dissolved solids.

17. Typical composition of dissolved solids, by percentage of chemical equivalents.............

18. Annual mean chloride concentrations. .........

19. Annual maximum chloride concentrations . . . . -

20. Frequency of chloride concentrations, 1930-61..-

21. Frequency of chloride concentrations, 1950-62 --

22. Mean monthly chloride concentrations...........

23. Annual mean dissolved-oxygen concentrations. - -

24. Annual minimum dissolved-oxygen concentra-

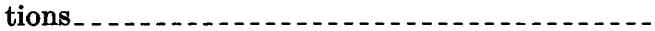

25. Frequency of dissolved-oxygen concentrations...

26. Mean monthly dissolved oxygen concentrations. -

27. Dissolved-oxygen concentrations in four periods

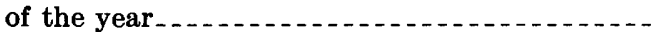

28. Annual suspended-sediment concentrations...... 29. Mean monthly suspended-sediment concentrations.........................................

\section{TABLES}

TABLE 1. Distance relations and drainage area of sampling stations in Delaware estuary, Burlington-Bristol Bridge to Marcus Hook $\mathrm{Pa}$

2. Monthly and annual mean water discharge, in cubic feet per second, Delaware River at Trenton, N.J., 1945-63

3. Time required to flush Delaware River upstream from sampling locations, at various discharge rates.

4. "Age" of river water at mean tidal range

5. Comparison of ratios of dissolved solids in Delaware River at Trenton and Marcus Hook with ratios of dissolved solids in ocean water.

6. Number of days each year in which selected chloride concentrations were exceeded for a salt-water invasion, Delaware River at Bridesburg, Chester, and Marcus Hook, Pa., and average June to October discharge at Trenton, N.J., for each year

7. Number of days dissolved-oxygen concentration was less than 1 and $3 \mathrm{ppm}$ at three dissolved-oxygen recorders in Delaware River, March 1961-December 1963

8. Physical description of sampling locations.

9. Range and frequency distribution of selected percentile groups of water-quality parameters, Delaware River, 1949-63 .....

10. Annual maximum, mean, and minimum of water-quality parameters, Delaware River, 1950-63

11. Monthly maximum, mean, and minimum of water-quality parameters, Delaware River, 1949-63 


\title{
CONTRIBUTIONS TO THE HYDROLOGY OF THE UNITED STATES
}

\section{DELAWARE RIVER WATER QUALITY, BRISTOL TO MARGUS HOOK, PENNSYLVANIA, AUGUST 1949 TO DECEMBER 1963}

\author{
By W. B. Keighton
}

\begin{abstract}
During the 14-year period from August 1949 to July 1963, the U.S. Geological Survey, in cooperation with the city of Philadelphia, collected samples of river water once each month in the 43-mile reach of the Delaware River from Bristol to Marcus Hook, Pa., and daily at Trenton, 10 miles upstream from Bristol. This part of the Delaware is an estuary into which salt water is brought by tides; fresh water flows into the estuary at Trenton, N.J., and farther downstream from the Schuylkill River and other tributaries of the Delaware.
\end{abstract}

In March, April, and May, when fresh-water flow is high, the average concentration of dissolved solids in the water at Bristol was $76 \mathrm{ppm}$ (parts per million), and at Marcus Hook 112 ppm. In August and September, streamflow is lower, and the average concentrations of dissolved solids increased to $\mathbf{1 1 7}$ ppm at Bristol and $804 \mathrm{ppm}$ at Marcus Hook. Major salinity invasions of the Delaware River occurred in 1949, 1953, 1954, 1957, and 1963. In each of these years the fresh-water flow into the tidal river at Trenton was low during the period from July to October. The greatest dissolved-solids concentrations in these monthly samples were $160 \mathrm{ppm}$ at Bristol and 4,000 ppm at Marcus Hook.

At times the dissolved-oxygen concentration of the river water has become dangerously low, especially in that reach of the river between Wharton Street and League Island. At the Benjamin Franklin Bridge, one-third of the samples of river water were less than 30 percent saturated with oxygen; however, no trend, either for better or for worse, was apparent during the 14-year period.

It is useful now to summarize these monthly analyses for the period 1949-63 even though a much more detailed description of water quality in this reach of the estuary will soon become available through the use of recording instruments. This period includes a range of conditions and exhibits the extent to which water-quality parameters varied with change in hydrologic and environmental conditions. This compendium of water-quality data is useful as an explicit statement of water quality during the 14-year period and is valuable for directing attention to water-quality problems, for selecting instrument sites, and for making comparative studies with the more detailed information which is already being obtained with the aid of recording instruments.

\section{INTRODUCTION}

The Delaware River from Trenton to the ocean is an estuary in which saline water moves down and upstream twice daily with the ebb and flood of the tide and mixes with the fresh water that flows 
into the estuary from the head of tide at Trenton and from the Schuylkill River and other tributaries below the head of tide. The changes in chemical quality of the river water are of interest to those who would understand water quality in this or any estuary. Furthermore, these changes are important because that part of the estuary described in this report is within a populous and industrialized region that depends upon the estuary for a source of water for household and industrial use and also makes use of the estuary to dilute and carry away its wastes. Because the estuary is a major source of water in this region, a knowledge of water quality in the estuary is of interest to many municipalities and industries, as well as to individual citizens, sportsmen, and conservation groups.

The U.S. Geological Survey has collected monthly water samples in the Delaware estuary since August 1949 at eight sampling stations from Bristol, Pa., to the Pennsylvania-Delaware State line at Marcus Hook, Pa. The location of these stations is shown in figure 1 , and

TABLE 1.-Distance relations and drainage area of sampling stations in Delaware estuary, Burlington-Bristol Bridge to Marcus Hook, Pa.

\begin{tabular}{|c|c|c|c|c|}
\hline & \multirow{2}{*}{ Station 1} & \multirow{2}{*}{$\begin{array}{l}\text { Drainage } \\
\text { area, in } \\
\text { square } \\
\text { miles }\end{array}$} & \multicolumn{2}{|c|}{$\begin{array}{l}\text { River distance, in miles, } \\
\text { of midchannel stations }\end{array}$} \\
\hline & & & $\begin{array}{l}\text { Between } \\
\text { stations }\end{array}$ & $\begin{array}{l}\text { From Tren- } \\
\text { ton, N.J. }\end{array}$ \\
\hline $\begin{array}{l}1 \\
2 \\
3 \\
4 \\
5 \\
6 \\
7 \\
8\end{array}$ & $\begin{array}{l}\text { Bristol (Pa.)-Burlington (N.J.) Bridge } \\
\text { Torresdale, Philadelphia, Pa. } \\
\text { Lehigh Avenue, Philadelphia, Pa. } \\
\text { Benjamin Franklin Bridge } \\
\text { Wharton Street, Philadelphia, Pa } \\
\text { League Island, Philadelphia, Pa } \\
\text { Eddystone, Pa } \\
\text { Marcus Hook, Pag }\end{array}$ & $\begin{array}{r}7,160 \\
7,781 \\
7,935 \\
7,993 \\
7,998 \\
8,072 \\
10,190 \\
10,370\end{array}$ & $\begin{array}{l}8.1 \\
8.0 \\
1.8 \\
1.5 \\
5.4 \\
8.7 \\
6.0\end{array}$ & $\begin{array}{l}\text { 15. } 2 \\
23.3 \\
31.3 \\
33.1 \\
34.6 \\
40.0 \\
48.7 \\
54.7\end{array}$ \\
\hline
\end{tabular}

1 For location of stations, see fig. 1.

the stations are listed in table 1 . In addition, a daily sampling station has been operated, above the head of tide, on the Delaware River at Trenton, N.J., since 1944. The four upstream stations were sampled on one day, and the four downstream stations on the following day, or vice versa. Sampling trips were scheduled without regard to possible tidal, climatic, or other environmental conditions. Most of the trips to date have been completed within the first 10 days of each month. At times, owing to inclement winter weather, it was hazardous to sample by boat. For this reason, actual data are occasionally missing for a winter month; however, in compiling the summaries of data in this report such missing data have been estimated empirically from long-term information. 


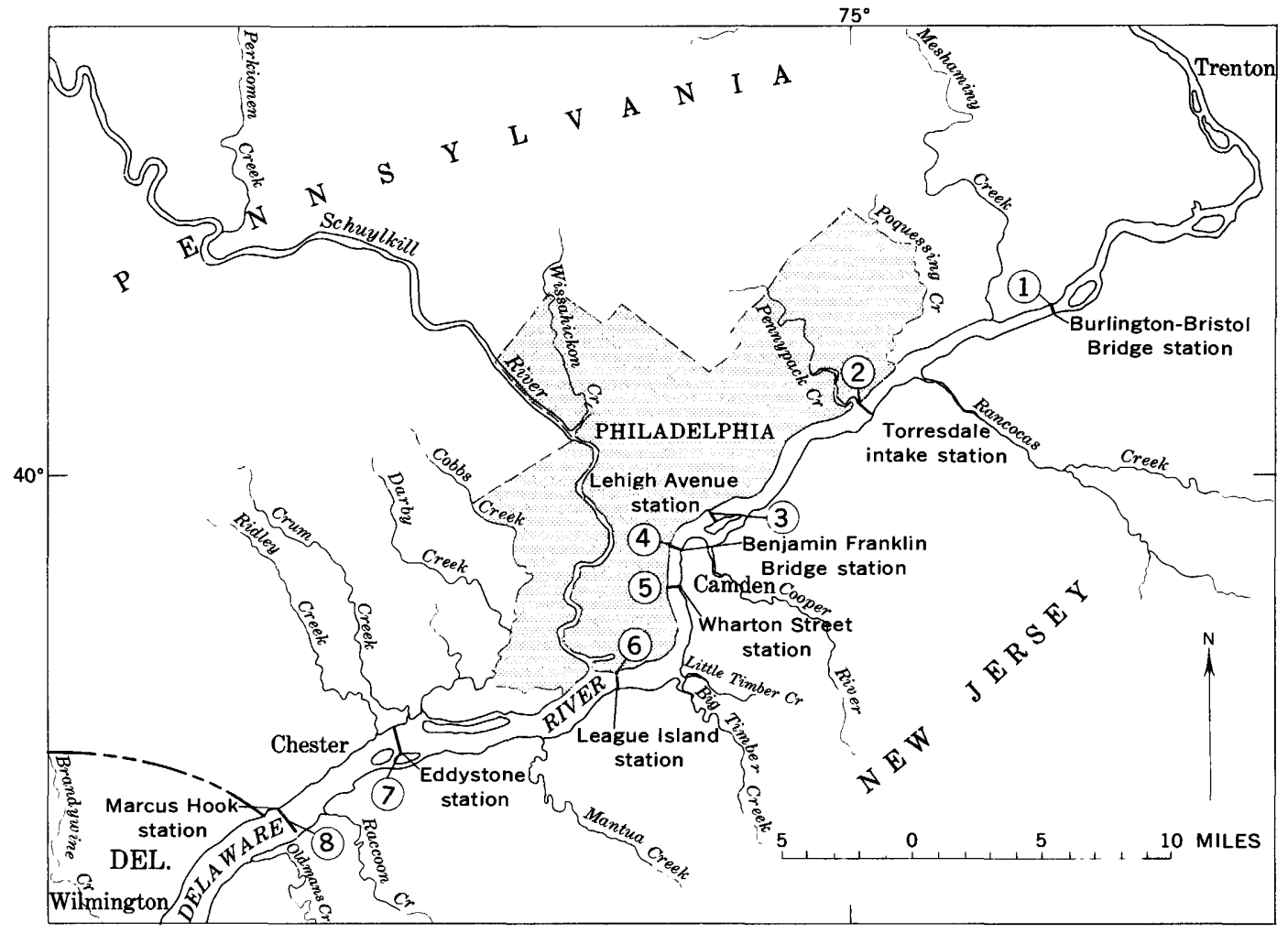

FIgURE 1.-Location of water-quality sampling stations along Delaware estuary, Trenton, N.J., to Marcus Hook, Pa. 


\section{PURPOSE AND SCOPE}

In the 14-year period from August 1949 to December 1963, many analytical data were collected describing the chemical and physical quality of water in the Delaware estuary between Bristol and Marcus Hook. Most of these analyses have already been published in annual reports of the U.S. Geological Survey. To refer to these data, it is necessary, however, to consult more than a dozen publications; and to comprehend the meaning of the many analyses, it is necessary to compare water quality at eight sampling locations for 14 years and for the 12 months of each year.

This report presents, in summary form, the water-quality facts discovered at these eight sampling stations during the period August 1949 to December 1963. It has been written to serve as a reference book of the important facts concerning the water quality of the Delaware River from Bristol to Marcus Hook and presents a historical record of the variations in water quality without analyzing their causes. It does not record the basic chemical analyses, water temperatures, or suspended sediment analyses which have already been published but instead summarizes, plots, and compares the basic data in order to facilitate comprehension of them. Water-quality facts are presented in two complementary ways: on pages O9-036 the salient features are shown graphically; on pages O36-O51 the data are summarized in tabular form for each of the eight sampling stations. In both the graphic and the tabular section, I have tried to distill the analyses to obtain the essence.

It is hoped that this compendium will facilitate the task of those who need to know the quality of water in the estuary, or who desire to study the factors that influence the quality of the water and that cause the variations observed. It should also be useful in directing attention to water-quality problems and in selecting future sites for instruments and observations.

\section{PREVIOUS INVESTIGATIONS AND ACKNOWLEDGMENTS}

Analyses of water samples collected from August 1949 to December 1952 are reported and interpreted in "Chemical Characteristics of Delaware River Water, Trenton, New Jersey, to Marcus Hook, Pennsylvania" (Durfor and Keighton, 1954). Since 1952 the water analyses have been published in the annual Geological Survey WaterSupply Paper series entitled "Quality of Surface Waters of the United States." These papers are listed below:

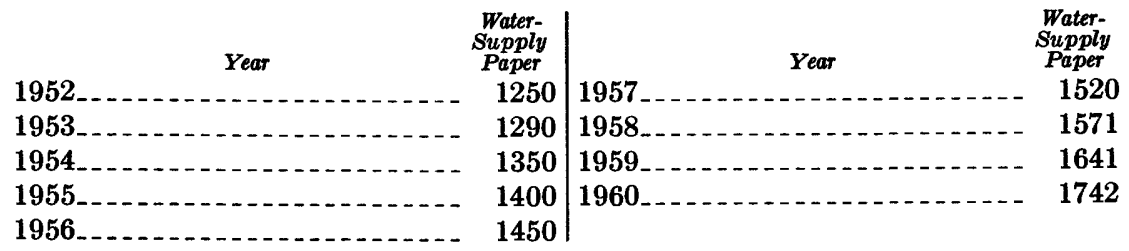


In addition to these compilations of water-quality data, three recent publications of the Geological Survey have reported on interpretations of these data. Cohen and McCarthy (1962) in "Salinity of the Delaware Estuary" discuss the environmental variables affecting salinity in the estuary. Durfor and Anderson (1963) in a report describing the chemical character of streams in Pennsylvania briefly discuss water quality in the estuary. A third report is a comprehensive discussion of the quality of water entering the estuary at Trenton-"Quality of Delaware River Water at Trenton, New Jersey" by McCarthy and Keighton (1964).

These investigations of the chemical quality of the Delaware estuary from 1949 to 1963 have been conducted by the Geological Survey, in cooperation with the city of Philadelphia Water Department, Samuel S. Baxter, commissioner. They were under the general supervision of W. F. White, district chemist, 1948-52, and N. H. Beamer, district chemist from 1952 to the present. The author wishes to express his debt to Leo T. McCarthy, Jr., and Frederick L. Schaefer for compiling the tables and preparing the illustrations which are the backbone of this report.

\section{SOME BASIC PHYSICAL AND HYDROLOGIC FACTS}

The Delaware estuary begins at the head of tide at Trenton, N.J. Approximately 1 mile upstream from the head of tide, the U.S. Geological Survey maintains a stream-gaging station that has been in continuous operation since 1912. Upstream from this gage the Delaware River has a drainage area of 6,780 square miles, which is about 95 percent of the drainage area at Burlington-Bristol Bridge but only about 65 percent of the drainage area at Marcus Hook. The seasonal variations in water discharge of the river at Trenton have a direct influence on the chemical, physical, and sanitary quality of the Delaware estuary. To aid in the interpretation of the waterquality data presented in this report, the annual mean discharges and the monthly mean discharges at Trenton, N.J., for 1945-63 are presented in table 2 and plotted in figures 2 and 3.

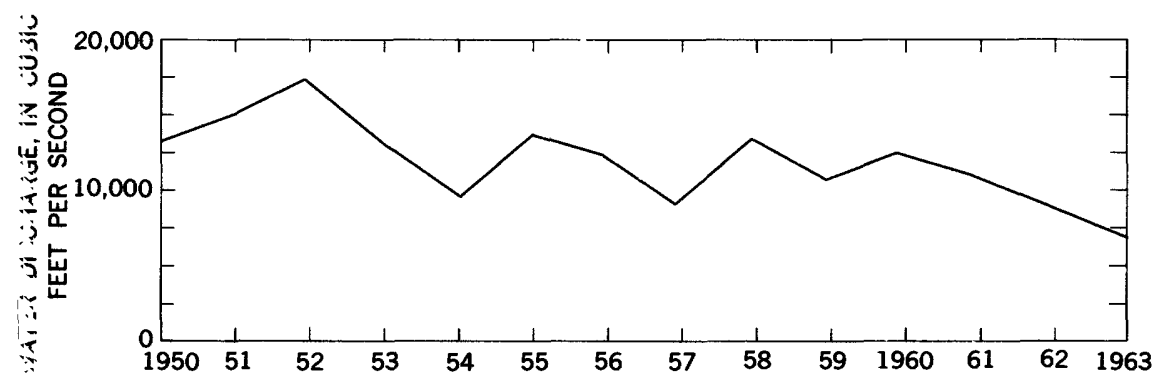

Figure 2.-Annual mean water discharge of the Delaware River at Trenton, N.J., 1950-63. 
TABLE 2.-Monthly and annual mean water discharge, in cubic feet per second, Delaware River at Trenton, N.J., 1945-63

\begin{tabular}{|c|c|c|c|c|c|c|c|c|c|c|c|c|c|}
\hline Year & Ianuary & February & March & April & May & June & July & August & September & October & November & December & Annual \\
\hline $\begin{array}{l}45 \\
46 \\
47 \\
48 \\
49 \\
50\end{array}$ & $\begin{array}{r}10,060 \\
17,730 \\
12,440 \\
6,142 \\
32,430 \\
13,870 \\
18,500 \\
24,070 \\
22,160 \\
7,518 \\
10,400 \\
6,855 \\
9,698 \\
14,180 \\
10,490 \\
15,530 \\
4,711 \\
12,970 \\
6,541\end{array}$ & $\begin{array}{r}9,341 \\
7,954 \\
12,050 \\
11,450 \\
19,070 \\
13,320 \\
27,550 \\
18,680 \\
19,560 \\
14,530 \\
8,881 \\
13,150 \\
9,983 \\
10,330 \\
10,900 \\
18,220 \\
15,690 \\
8,133 \\
6,075\end{array}$ & $\begin{array}{r}37,100 \\
23,920 \\
19,250 \\
34,170 \\
13,560 \\
21,860 \\
23,230 \\
24,460 \\
25,690 \\
17,300 \\
20,970 \\
19,790 \\
13,370 \\
20,930 \\
14,740 \\
8,782 \\
24,900 \\
19,340 \\
23,500\end{array}$ & $\begin{array}{r}16,310 \\
8,841 \\
25,710 \\
26,010 \\
16,050 \\
24,360 \\
29,600 \\
36,230 \\
26,620 \\
13,980 \\
13,110 \\
30,900 \\
25,260 \\
39,230 \\
20,540 \\
33,280 \\
27,520 \\
23,440 \\
14,540\end{array}$ & $\begin{array}{r}19,730 \\
20,010 \\
30,350 \\
21,980 \\
16,030 \\
13,560 \\
8,533 \\
22,750 \\
20,050 \\
16,980 \\
6,455 \\
18,040 \\
8,385 \\
20,280 \\
8,246 \\
11,280 \\
16,120 \\
6,147 \\
8,092\end{array}$ & $\begin{array}{r}14,280 \\
17,720 \\
14,290 \\
12,920 \\
5,682 \\
11,550 \\
8,049 \\
13,520 \\
7,224 \\
5,092 \\
5,017 \\
10,150 \\
4,297 \\
6,214 \\
4,598 \\
10,790 \\
7,130 \\
3,407 \\
4,332\end{array}$ & $\begin{array}{r}25,380 \\
7,885 \\
19,730 \\
7,727 \\
3,721 \\
7,574 \\
8,336 \\
12,010 \\
3,783 \\
2,080 \\
2,477 \\
8,413 \\
2,907 \\
\mathbf{4}, 667 \\
3,868 \\
6,197 \\
5,150 \\
2,489 \\
3,116\end{array}$ & $\begin{array}{r}14,050 \\
5,505 \\
9,074 \\
5,726 \\
2,701 \\
4,915 \\
6,874 \\
6,307 \\
2,435 \\
1,828 \\
30,290 \\
4,045 \\
2,018 \\
3,700 \\
4,018 \\
7,433 \\
5,605 \\
3,010 \\
2,928\end{array}$ & $\begin{array}{r}12,390 \\
4,317 \\
5,015 \\
3,272 \\
2,719 \\
4,721 \\
4,206 \\
10,040 \\
2,695 \\
3,495 \\
7,410 \\
5,613 \\
2,254 \\
4,029 \\
4,255 \\
19,340 \\
4,205 \\
2,631 \\
2,556\end{array}$ & $\begin{array}{r}13,230 \\
5,807 \\
3,159 \\
3,107 \\
2,785 \\
3,149 \\
5,640 \\
3,640 \\
2,409 \\
2,487 \\
28,710 \\
5,180 \\
2,381 \\
8,235 \\
8,030 \\
7,623 \\
2,903 \\
4,515 \\
2,108\end{array}$ & $\begin{array}{r}18,010 \\
4,750 \\
14,700 \\
6,202 \\
4,661 \\
14,250 \\
24,350 \\
12,850 \\
5,866 \\
12,770 \\
21,630 \\
8,192 \\
3,905 \\
12,100 \\
13,380 \\
6,221 \\
5,343 \\
10,860 \\
4,025\end{array}$ & $\begin{array}{r}15,300 \\
4,648 \\
8,030 \\
10,770 \\
10,940 \\
26,050 \\
18,590 \\
26,130 \\
17,830 \\
13,110 \\
7,742 \\
16,170 \\
19,830 \\
9,285 \\
19,400 \\
5,010 \\
6,334 \\
7,318 \\
7,271\end{array}$ & $\begin{array}{r}17,098 \\
10,757 \\
14,483 \\
12,456 \\
10,862 \\
13,265 \\
15,288 \\
17,557 \\
13,027 \\
9,264 \\
13,591 \\
12,208 \\
8,691 \\
12,765 \\
10,205 \\
12,476 \\
10,468 \\
8,688 \\
7,090\end{array}$ \\
\hline aximum_ & 32,430 & 27,550 & 37,100 & 39,230 & 30,350 & 17,720 & 25,380 & 30,290 & 19,340 & 28,710 & 24,350 & 26,130 & 17,557 \\
\hline & 13,486 & 13,413 & 21,313 & 23,768 & & & & & & & 10,740 & 13,145 & 12,113 \\
\hline - & 4,711 & 6,075 & 8,782 & 8,841 & 6,147 & 3,407 & 2,080 & 1,828 & 2,254 & 2,108 & 3,905 & 4,648 & 7,090 \\
\hline
\end{tabular}




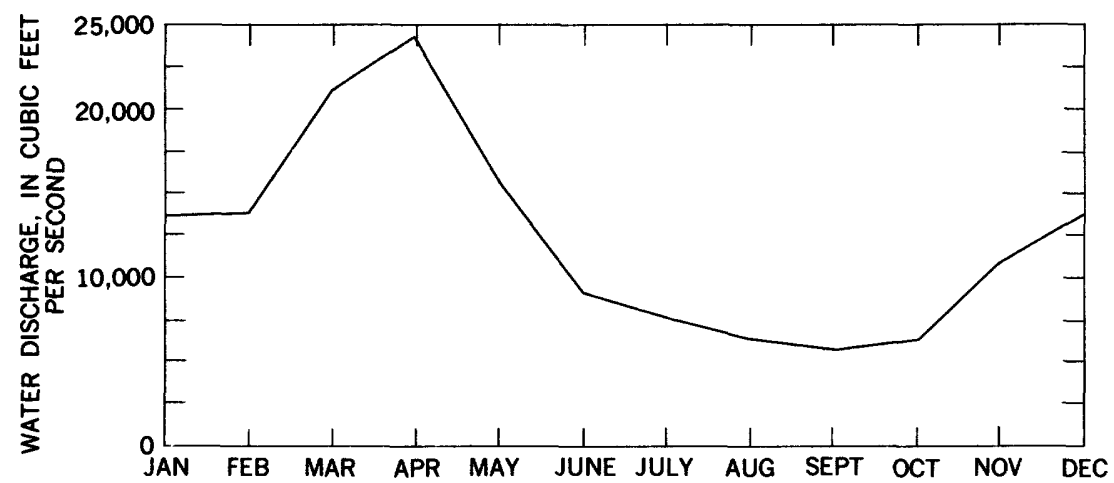

Figure 3.-Mean monthly water discharge of the Delaware River at Trenton, 1949-63.

Fresh water flowing into the estuary both dilutes salt water and tends to flush it downstream. For example, a discharge of $6,000 \mathrm{cfs}$ (cubic feet per second) for 1 day is $5.18 \times 10^{8}$ cubic feet per day. The volume of water (at midtide) in the river between Trenton and Marcus Hook is $170 \times 10^{8}$ cubic feet. On this basis it is estimated that 33 days $(170 / 5.18)$ would be required to flush the river to Marcus Hook. The results of such calculations for several discharge rates are given in table 3; however, fresh water also dilutes salt water by tidal mixing, so that the river is generally freshened more rapidly than indicated in the table. When the fresh-water flow is very low, salt water may advance upstream in spite of the freshwater discharged.

TABLE 3.-Time required to flush Delaware River upstream from sampling locations, at various discharge rates

\begin{tabular}{|c|c|c|c|c|c|c|c|c|}
\hline \multirow{2}{*}{$\begin{array}{l}\text { Water discharge at Trenton, } \\
\text { N.J. } \\
\text { (cfs) }\end{array}$} & \multicolumn{8}{|c|}{ Flushing time, in days, from Trenton to station indicated 1} \\
\hline & 1 & 2 & 3 & 4 & 5 & 6 & 7 & 8 \\
\hline $\begin{array}{l}6,000 \\
\mathbf{4 0}, 000\end{array}$ & $\begin{array}{r}3.2 \\
1.9 \\
.5\end{array}$ & $\begin{array}{r}6.0 \\
3.6 \\
.9\end{array}$ & $\begin{aligned} 10 \\
6.2 \\
1.6\end{aligned}$ & $\begin{array}{r}11 \\
6.8 \\
1.7\end{array}$ & $\begin{aligned} 12 \\
7.4 \\
1.9\end{aligned}$ & $\begin{array}{l}17 \\
10 \\
2.5\end{array}$ & $\begin{array}{l}25 \\
15 \\
3.8\end{array}$ & $\begin{array}{l}33 \\
20 \\
4.9\end{array}$ \\
\hline
\end{tabular}

1 For location of stations $1-8$, see fig. 1.

The average concentration of dissolved solids in water of the Delaware River at Trenton from 1945 to 1961 was $86 \mathrm{ppm}$ and ranged from 57 to $126 \mathrm{ppm} 90$ percent of the time. In March, April, and May the median concentration of dissolved solids was $66 \mathrm{ppm}$, and in August and September $107 \mathrm{ppm}$. The dissolved solids aver- 
aged, in terms of equivalents, 28 percent calcium, 14 percent magnesium, 8 percent sodium plus potassium, 43 percent bicarbonate plus sulfate, 5 percent chloride, and 2 percent nitrate (McCarthy and Keighton, 1964).

Other tributaries also contribute tresh water to the estuary and thereby have some influence on water quality. Of these, the principal tributary is the Schuylkill River, which flows into the Delaware River close to, but downstream from, station 6-League Island (fig. 1). The Schuylkill River may be expected to exert some influence on water quality downstream from its confluence, at Chester, Eddystone (sta. 7), and Marcus Hook (sta. 8). On a flood tide, water from the Schuylkill River may flow upstream in the Delaware River and dilute the water at League Island (sta. 6).

A gaging station has been maintained since 1931 on the Schuylkill River 8.4 miles upstream from the mouth and above tidal influences; the monthly and yearly mean discharges are reported annually in U.S. Geological Survey publications. The quantity of fresh water from the Schuylkill River flowing into the Delaware River each year is generally no more than one-quarter of the fresh-water inflow into the Delaware River at Trenton, N.J.; furthermore, the fresh water discharged from the Schuylkill River is mixed with a tidal flow many times as large.

An additional factor in the downstream movement of fresh water is the mixing effect of the twice daily ebbing and flooding of the tide. Ketchum (1951a, b) devised a method of calculating the time required for water to move from one part of a tidal estuary to another downstream location, taking into consideration the tidal mixing. In 1952 the author applied Ketchum's method to calculate the time of travel of a volume element of water from Trenton to several downstream locations. For example, at mean tidal range and a water discharge of 6,000 cfs at Trenton, N.J., calculations according to Ketchum's method show that $\mathbf{1 4 . 5}$ days are required for water to travel from Trenton to Marcus Hook. The water contributed by the Schuylkill River was included in these calculations. The "age" of fresh water at several locations, as calculated by Ketchum's method, is given in table 4. At a discharge of 3,000 cfs at Trenton, fresh water or a slug of pollution requires 6.6 days (17.6-11.0) at mean tidal range to travel from Benjamin Franklin Bridge to Marcus Hook. This flushing time is more rapid than that represented in table 3. 
TABLE 4.- "Age" of river water at mean tidal range

[Calculated by the method of B. H. Ketchum]

\begin{tabular}{|c|c|c|c|}
\hline \multirow[b]{2}{*}{$\begin{array}{l}\text { Water discharge at Trenton, N.J. } \\
\text { (cts) }\end{array}$} & \multicolumn{3}{|c|}{$\begin{array}{l}\text { "Age" of river water, in days, from Trenton } \\
\text { to station specified } 1\end{array}$} \\
\hline & $\mid \begin{array}{c}\text { Burlington- } \\
\text { Bristol Bridge }\end{array}$ & $\begin{array}{c}\text { Benjamin } \\
\text { Franklin } \\
\text { Bridge }\end{array}$ & Marcus Hook \\
\hline $\begin{array}{l}3,000 \\
6,000 \\
12,000\end{array}$ & $\begin{array}{l}5.8 \\
4.2 \\
2.7\end{array}$ & $\begin{array}{r}11.0 \\
8.6 \\
6.3\end{array}$ & $\begin{array}{l}17.6 \\
14.5 \\
11.5\end{array}$ \\
\hline
\end{tabular}

1 When the tidal range is a foot greater than the mean range, the "age" of the water at Marcus Hook is 1-2 days less; when the tidal range is a foot less than the mean, the "age" is 1-4 days greater.

\section{GRAPHIC SUMMARIES OF WATER-QUALITY FACTS}

The conspicuous variations in water quality in the river from Bristol to Marcus Hook, over the period from 1950 to 1963 , are presented graphically in this section. Generally, the water-quality characteristics are not plotted for all eight sampling locations, but only for enough of them so that the characteristics at the other locations may be estimated by interpolation.

Water-quality data are summarized on pages $\mathrm{O} 36-\mathrm{O} 51$, in tables which give an additional quantitative view of the variations in water quality. For example, the maximum, minimum, and mean values are given for several water-quality characteristics at each of the eight stations for the total period and for each month of the year. In addition, frequency distributions are given for several characteristics. Thus, the graphic and tabular presentation of the qualityof-water facts both complement and supplement each other.

\section{WATER TEMPERATURE}

The annual mean water temperatures varied from $55^{\circ}$ to $62^{\circ} \mathrm{F}$ (fig. 4) in the reach, the mean temperature at Marcus Hook being about $2^{\circ} \mathrm{F}$ warmer than at Bristol. The maximum water temperature recorded in any year was $86^{\circ} \mathrm{F}$, and the minimum temperature $33^{\circ} \mathrm{F}$. The frequency with which various water temperatures occurred is plotted in figure 5. For example, the median temperature was between $57^{\circ}$ and $60^{\circ} \mathrm{F}$ for the eight stations between Bristol and Marcus Hook; 10 percent of the samples had temperatures of $82^{\circ} \mathrm{F}$ or greater; and about one-third of the samples had temperatures exceeding $67^{\circ} \mathrm{F}$. The distribution of water temperatures is shown for each month in figure 6. Water temperatures are coldest in January, February, and March and warmest in July and August. The 


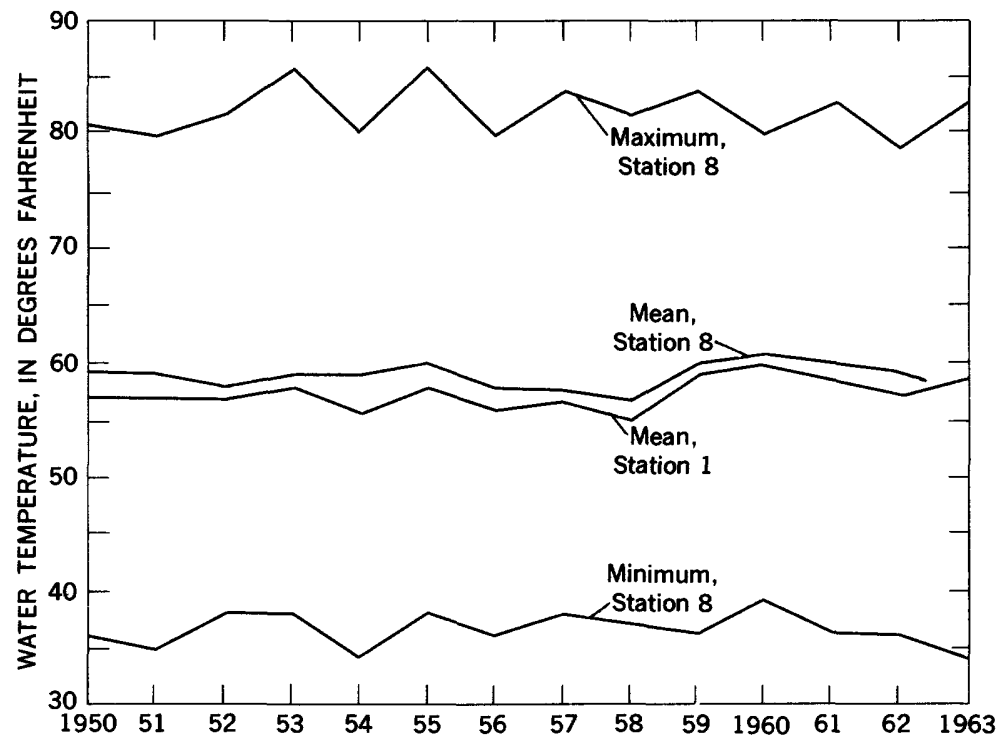

Frgure 4.-Annual mean water temperatures, Delaware River at Bristol, Pa. (sta. 1) and Marcus Hook (sta. 8), and annual maximum and minimum temperature at Marcus Hook, 1950-63.

greatest variability or range in temperatures from year to year is in June, September, October, and November.

\section{HYDROGEN-ION CONCENTRATION (pH)}

Hydrogen-ion concentration is expressed in $\mathrm{pH}$ units. A water having a $\mathrm{pH}$ of 7.0 is termed "neutral"; $\mathrm{pH}$ values greater than 7.0 indicate alkalinity; and those less than 7.0, acidity. Water in the Delaware River between Bristol and Marcus Hook varies from slightly basic to slightly acidic. The $\mathrm{pH}$ decreases slightly as the water flows downstream (figs. 7 and 8). From Burlington-Bristol Bridge to Torresdale, the median $\mathrm{pH}$ is 6.9 ; from Lehigh Avenue to League Island, 6.6; and from Eddystone to Marcus Hook, 6.5. More than half of the $\mathrm{pH}$ values at all locations are within $0.2 \mathrm{pH}$ units of these medians. There is no evidence of seasonal change in $\mathrm{pH}$.

\section{DISSOLVED-SOLTDS CONCENTRATION}

Because most of the substances dissolved in the water of the Delaware River estuary are ionized salts, the water conducts electricity. The specific electrical conductance of the water, therefore, is a measure of the dissolved-solids concentration. As the analytical determi- 
DELAWARE RIVER WATER, BRISTOL TO MARCUS HOOK 011

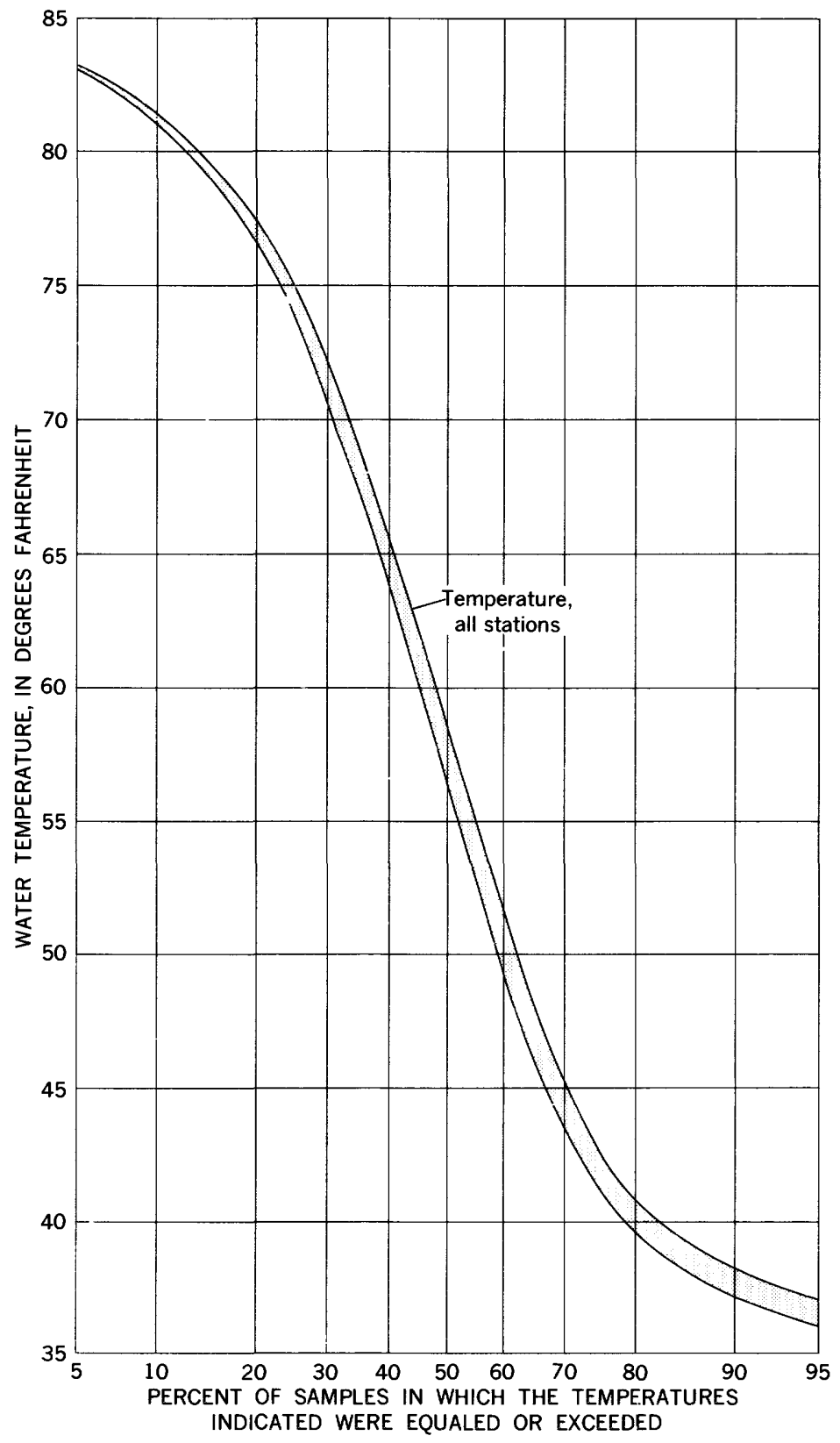

Figure 5.-Frequency of any given water temperature in Delaware River between Bristol and Marcus Hook, 1950-62. 
O12 CONTRIBUTIONS TO THE HYDROLOGY OF THE UNITED STATES
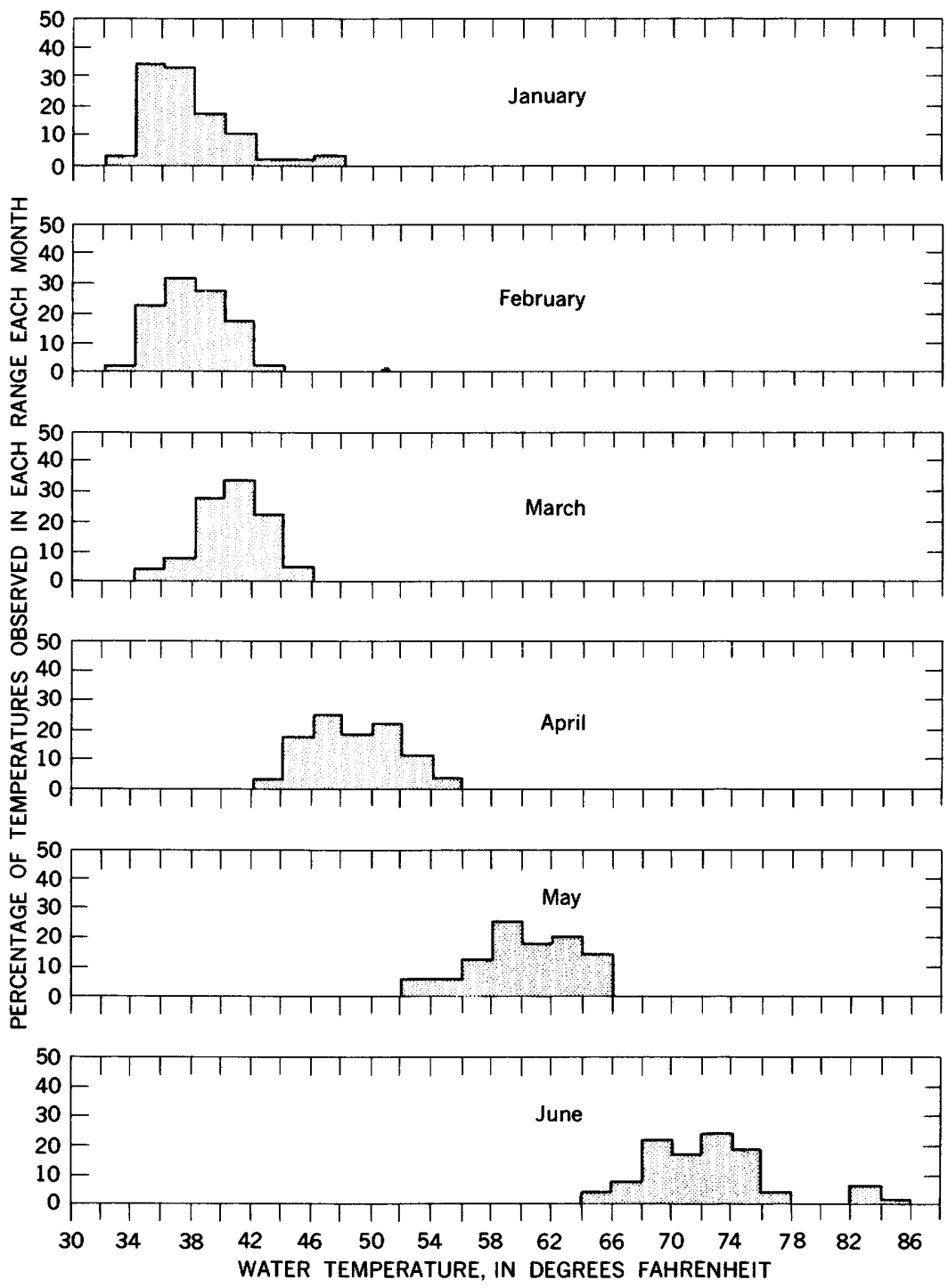

$$
A
$$

FiguRe 6.-Distribution of water temperatures each month 


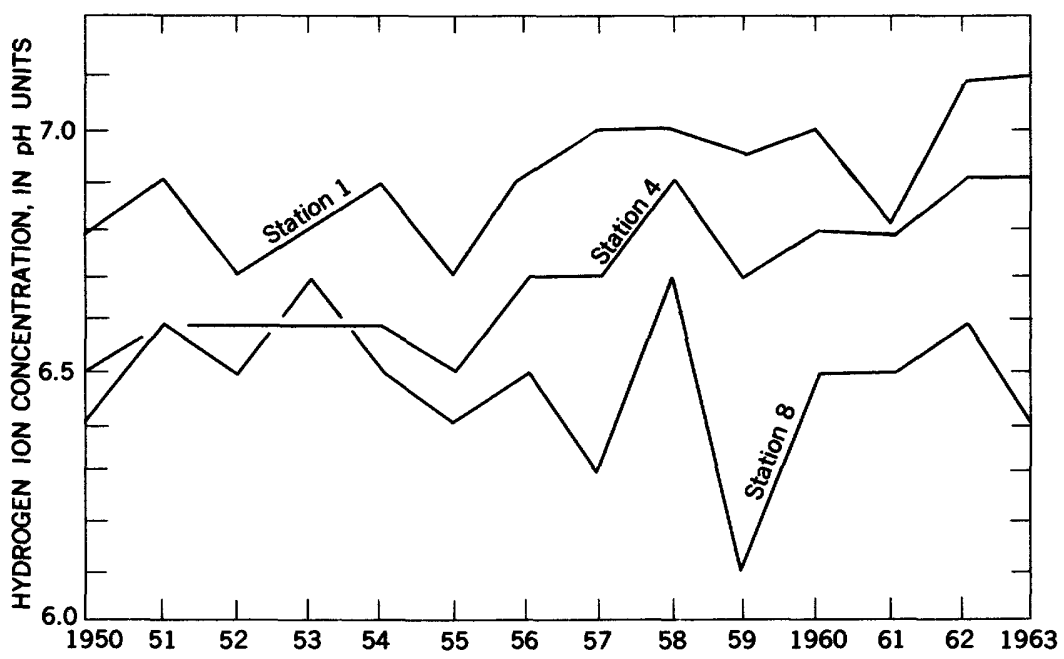

Figure 7.-Annual median pH values of water in Delaware River at Bristol (sta. 1), Benjamin Franklin Bridge (sta. 4), and Marcus Hook (sta. 8), 1950-63.

nation of dissolved solids is more expensive than the measurement of electrical conductivity, specific conductance is often available when the dissolved-solids concentrations are not. If specific conductance is the only data available, the dissolved-solids concentration may be estimated from it. Figures 9 and 10 are useful for making such estimates. In the range from 200 to $2,500 \mathrm{ppm}$ dissolved solids, the concentration is directly proportional to the specific conductance. From 2,500 to $4,500 \mathrm{ppm}$ the concentration can be estimated from the plotted $X$ 's.

The yearly variations in mean specific conductance are shown in figure 11, in which conductivity is plotted on a logarithmic scale. The annual mean conductivity at Bristol-Burlington Bridge varied from 135 to 186 micromhos (86-113 ppm dissolved solids), and at Marcus Hook from 228 to 2,330 micromhos (135-1,400 ppm dissolved solids). The maximum specific conductance for each year at six of the stations is plotted in figure 12. During the period 1950-63 the maximum specific conductance ranged from 167 to 266 micromhos at Bristol-Burlington Bridge (105-160 ppm dissolved solids) and from 370 to 6,120 micromhos $(220-4,000 \mathrm{ppm}$ dissolved solids) at Marcus Hook.

The frequencies of various concentrations of dissolved solids are plotted in figure 13. These concentrations have been estimated from the frequency of specific conductances. 
DELAWARE RIVER WATER, BRISTOL TO MARCUS HOOK O15

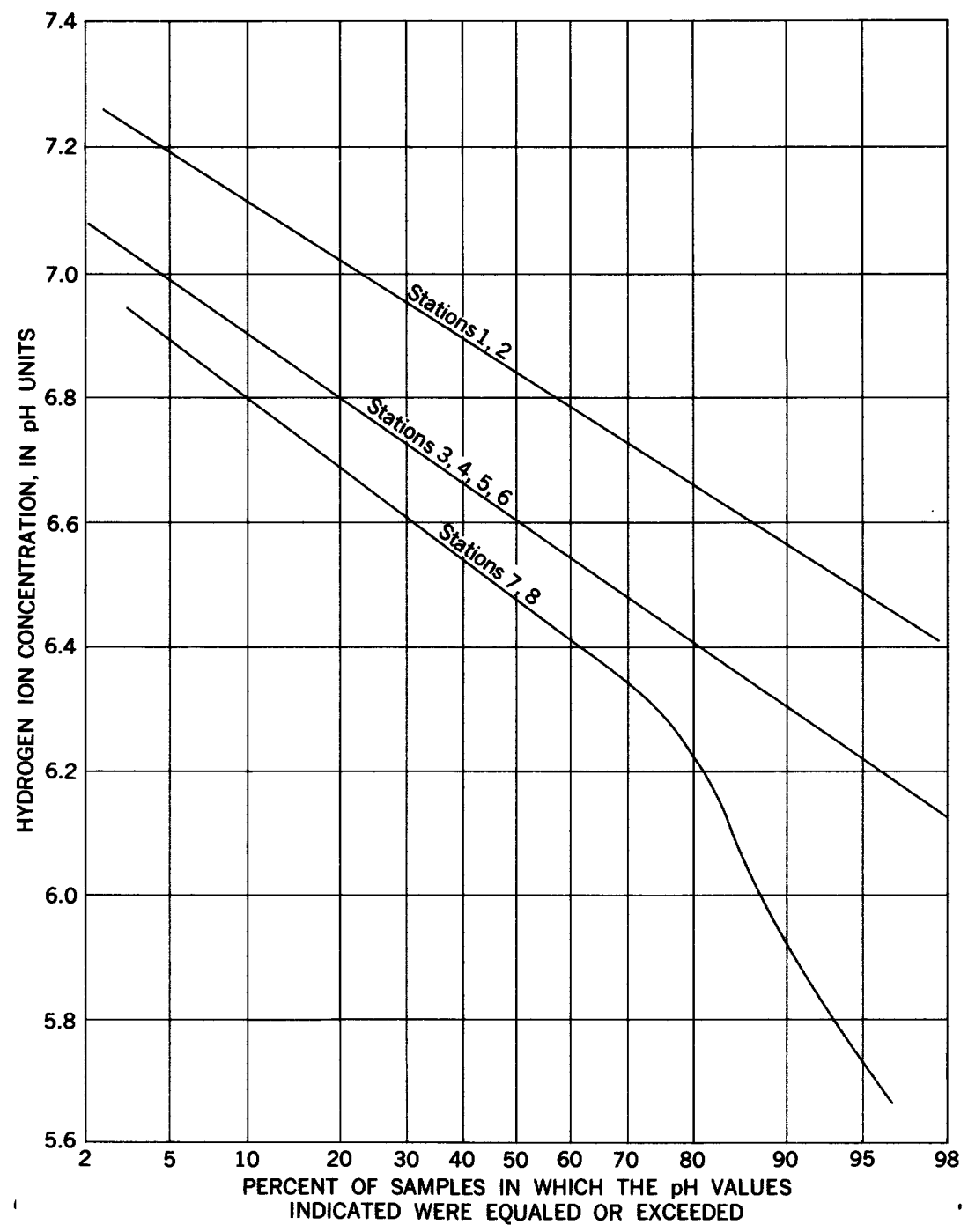

Figure 8.-Frequency of given $\mathrm{pH}$ values in Delaware River between Bristol and Marcus Hook, 1950-62. See figure 1 for location of stations.

In general, the greater the discharge of fresh water into the estuary, the lower is the specific conductance, and the lower the dissolved solids. If the fresh-water flow into the estuary at Trenton is less than 4,000 cfs for 30-60 days, the dissolved solids at Marcus Hook generally increases. When dissolved solids are high, an abrupt increase in streamflow, even for a few days duration, is likely to flush the salty water downstream. After an increase in fresh-water dis- 


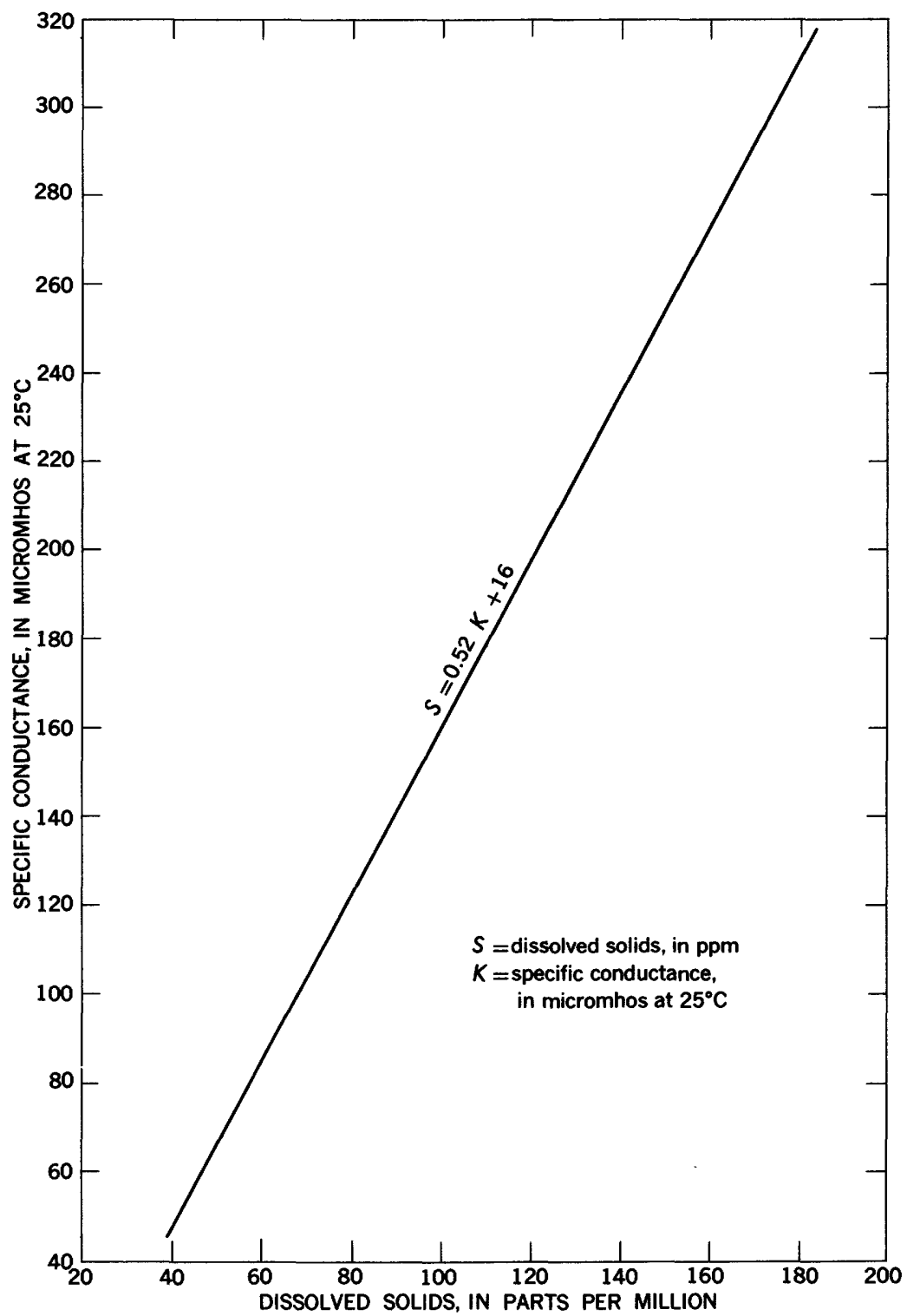

Figure 9.-Relation between electrical conductivity and dissolved solids (below $200 \mathrm{ppm}$ ) in Delaware River between Bristol and Marcus Hook, from Durfor and Keighton (1954).

charge, the salinity is reduced first in the upstream section of the river, then progressively downstream, if the increased fresh-water discharge persists. If the fresh-water flow decreases, the salinity increase first takes place far downstream below Marcus Hook and 


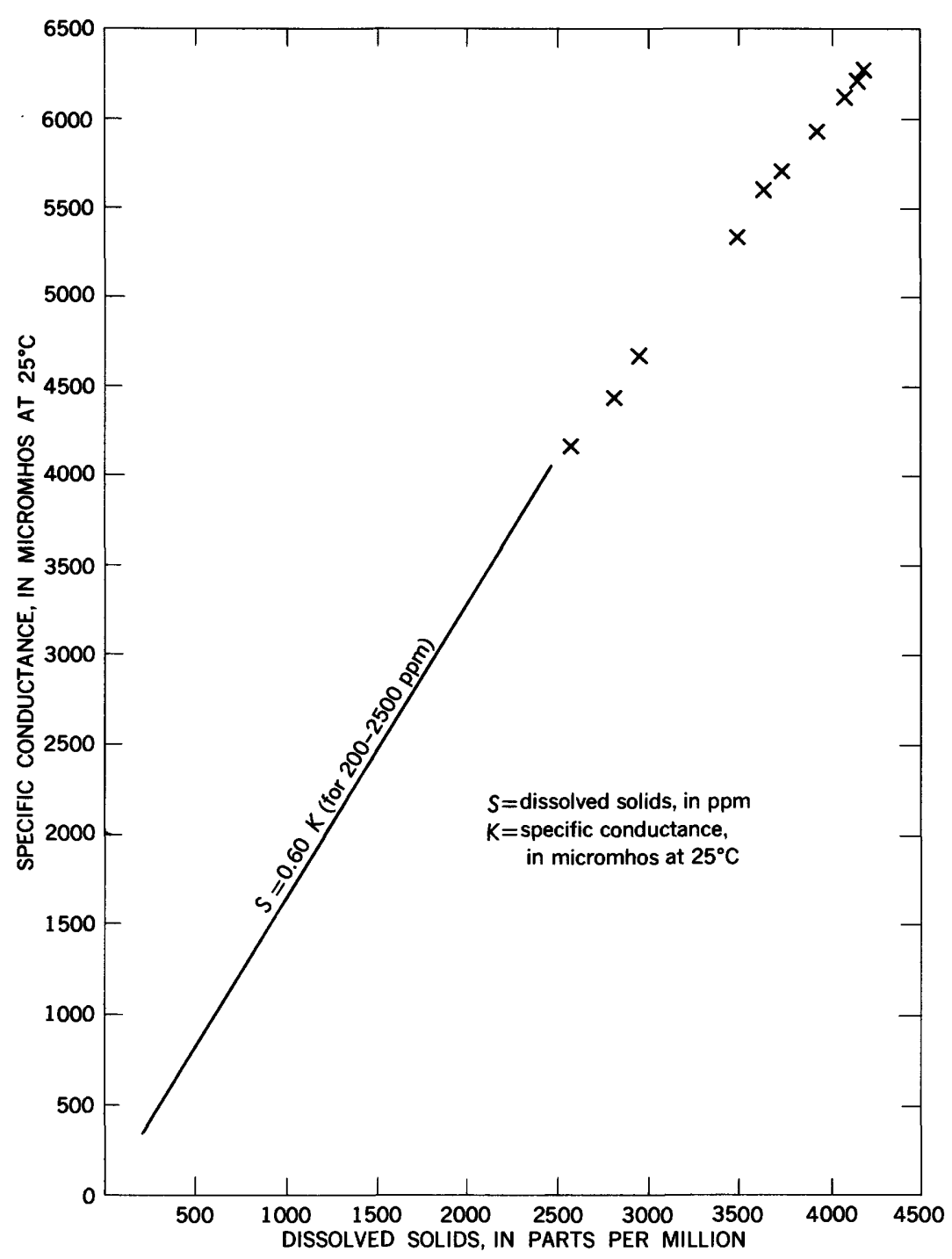

FIGURE 10.- Relation between electrical conductivity and dissolved solids $(200-4,000 \mathrm{ppm})$ in Delaware River between Bristol and Marcus Hook, 1950-62.

then moves up river. Other factors, including wind direction and intensity, sea level, barometric pressure, and tidal range also affect the salinity of the water in the Delaware estuary; therefore, it is not possible to predict reliably the specific conductance of the water from the magnitude of the fresh-water discharge alone. 


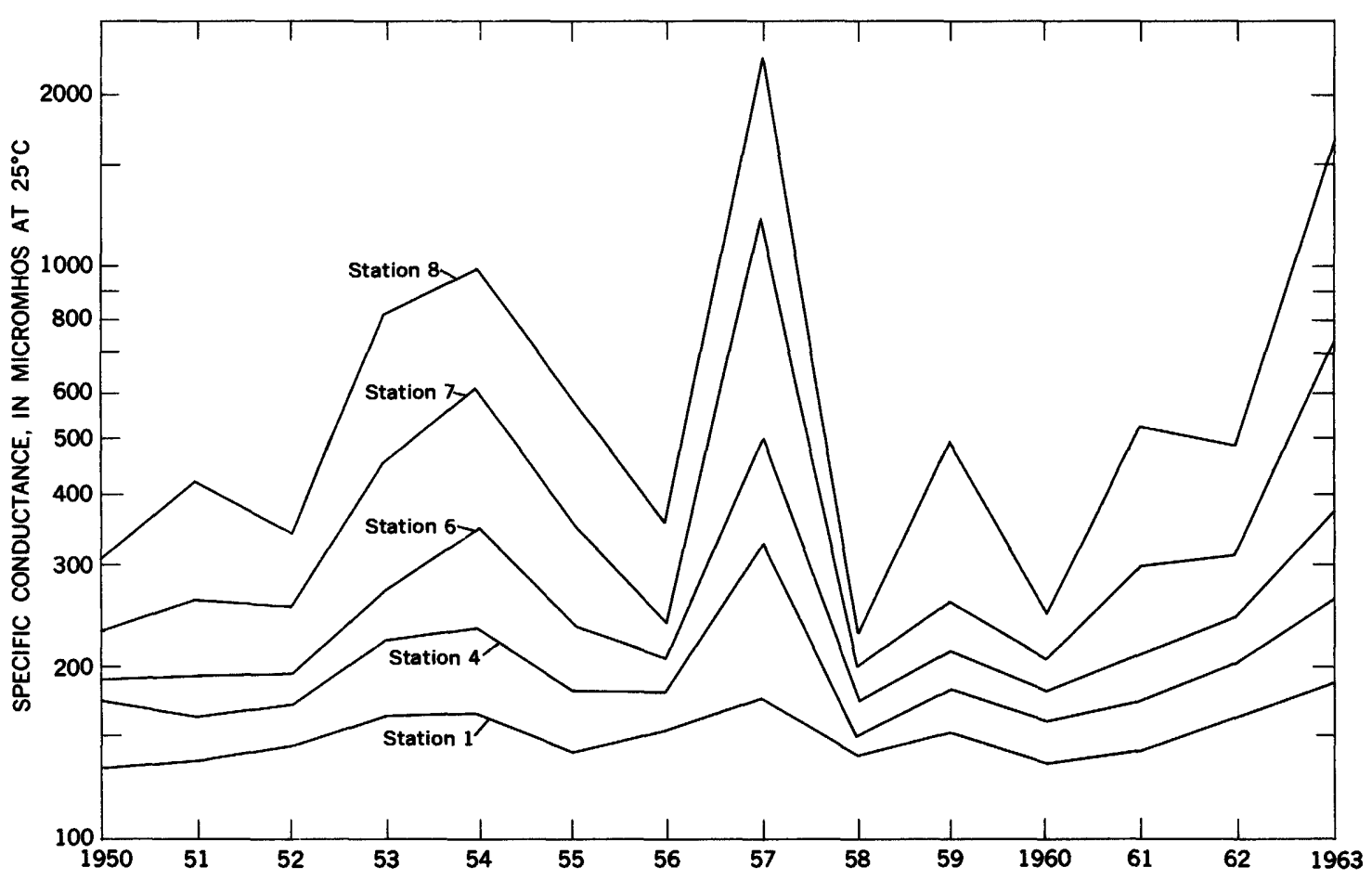

Figure 11.-Annual mean conductivities of water in Delaware River between Bristol and Marcus Hook, 1950-63. See figure 1 for location of stations $1,4,6,7$, and 8 . 


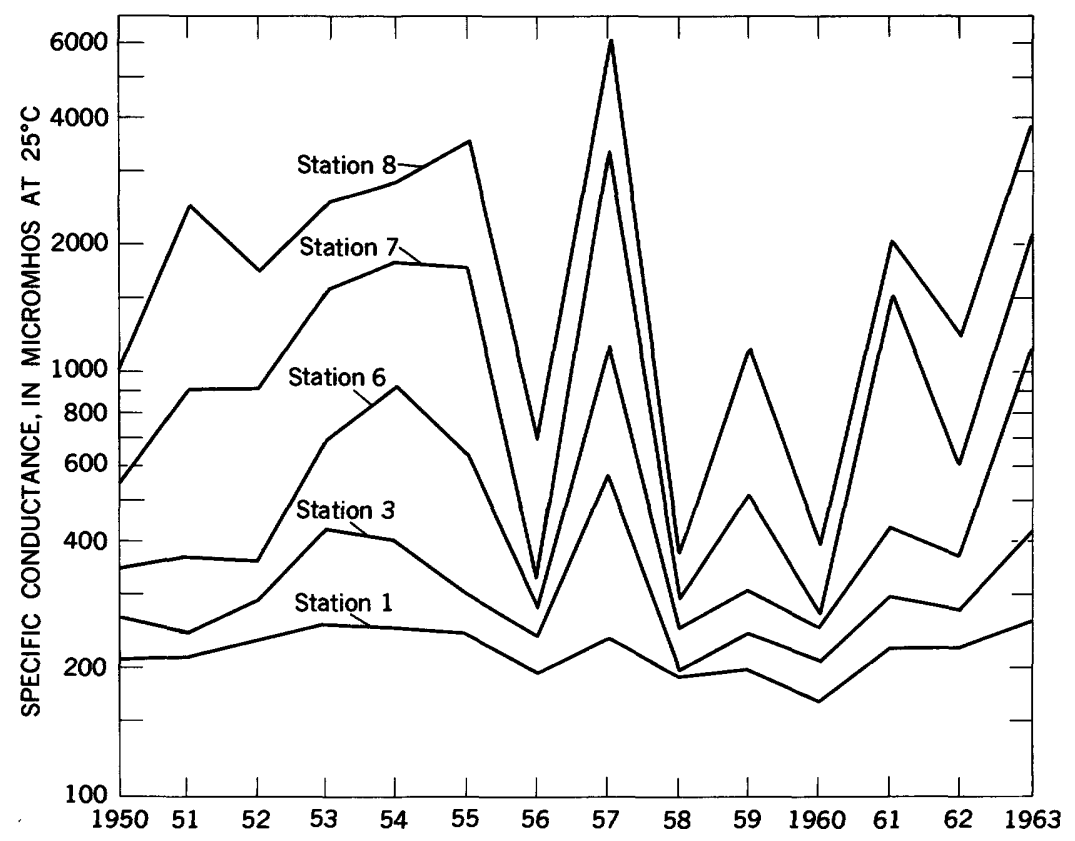

Frgure 12.-Annual maximum conductivities of water in Delaware River between Bristol and Marcus Hook, 1950-63. See figure 1 for location of stations $1,3,6,7$, and 8 .

The specific conductance decreases after a substantial increase in fresh-water discharge and increases after a sufficient reduction in fresh-water discharge. The gross effect of streamflow on salinity is evident in figure 14; in this figure the specific conductance at Marcus Hook and at Benjamin Franklin Bridge, and the fresh-water discharge at Trenton are plotted for each month of 1954. The mean monthly conductivity during 1949-63 for several locations is plotted in figure 15. Conductivity and dissolved solids are lowest in March, April, and May-months in which the fresh-water discharge is generally large - and highest in August to November.

\section{COMPOSITION OF DISSOIVED SOITS}

Composition of dissolved solids in the lower part of the estuary changes with concentration. Higher concentrations are generally the result of the sea water mixing with river water, and consequently, as the dissolved solids increase in concentration, the proportion of the several ions founds in the estuary water trends toward the proportion found in sea water. Thus, at higher concentrations sodium and chloride ions supplant the calcium bicarbonate and sulfate ions, 


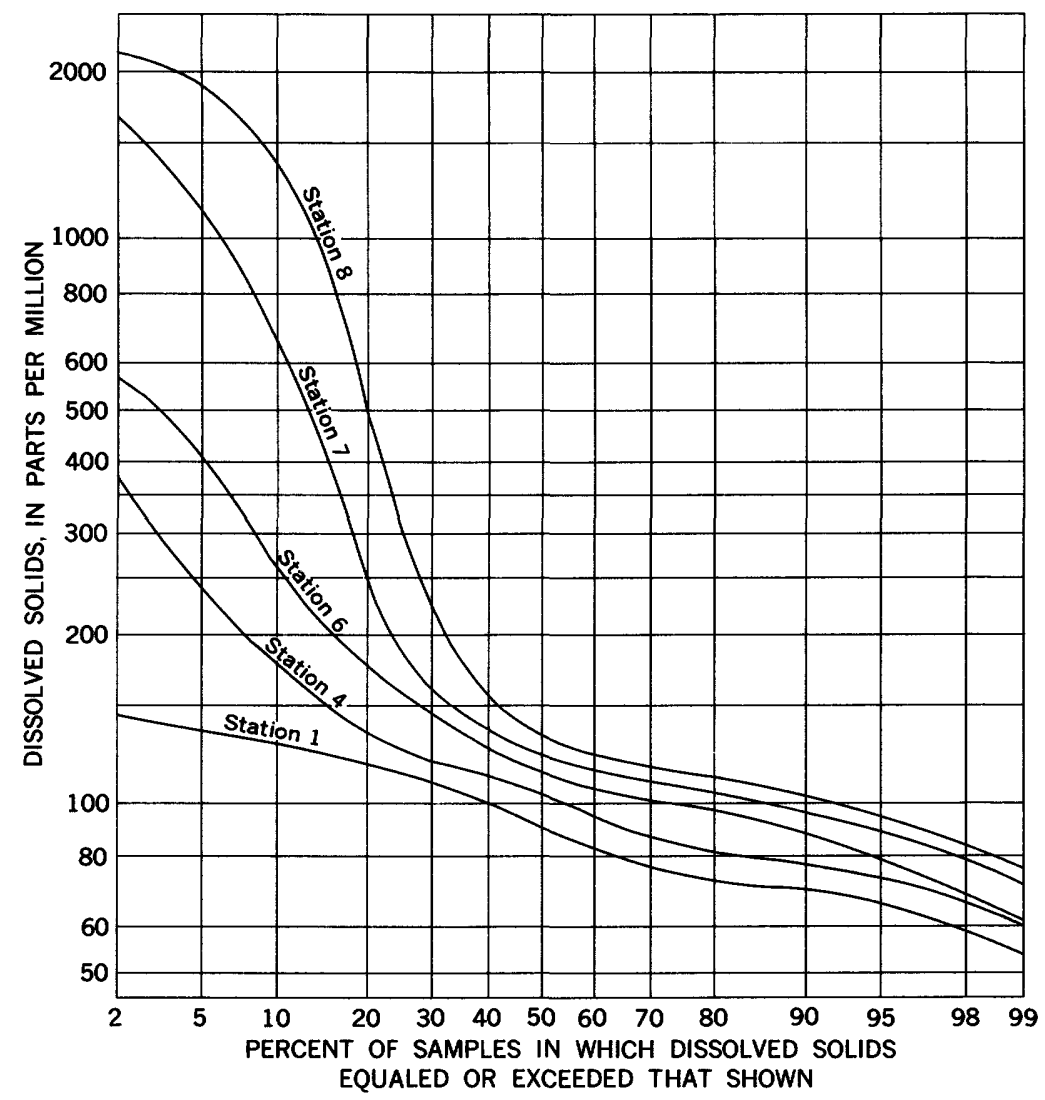

FiguRe 13.-Frequency of various dissolved-solids concentrations in Delaware River between Bristol and Marcus Hook, 1950-62. See figure 1 for location of stations $1,4,6,7$, and 8 .

which predominate at lower concentrations. This phenomenon is illustrated in figure 16. Compared to the water entering the estuary at Trenton, water in the estuary has less bicarbonate and more chloride at all concentrations. Estuary water is compared with the fresh water at Trenton in figure 17, the comparison being based on the chemical equivalents of each ion. The water at Trenton is a calcium bicarbonate-type. In the estuary the proportion of bicarbonate decreases and sulfate increases so that, at low concentrations, the estuary water can be described as a calcium bicarbonate-sulfate type. At higher concentrations the estuary water becomes a sodium chloride water, similar to ocean water.

Because they are related to specific conductance, dissolved-solids concentrations are also related to streamflow. Dissolved solids are 
DELAWARE RIVER WATER, BRISTOL TO MARCUS HOOK 021

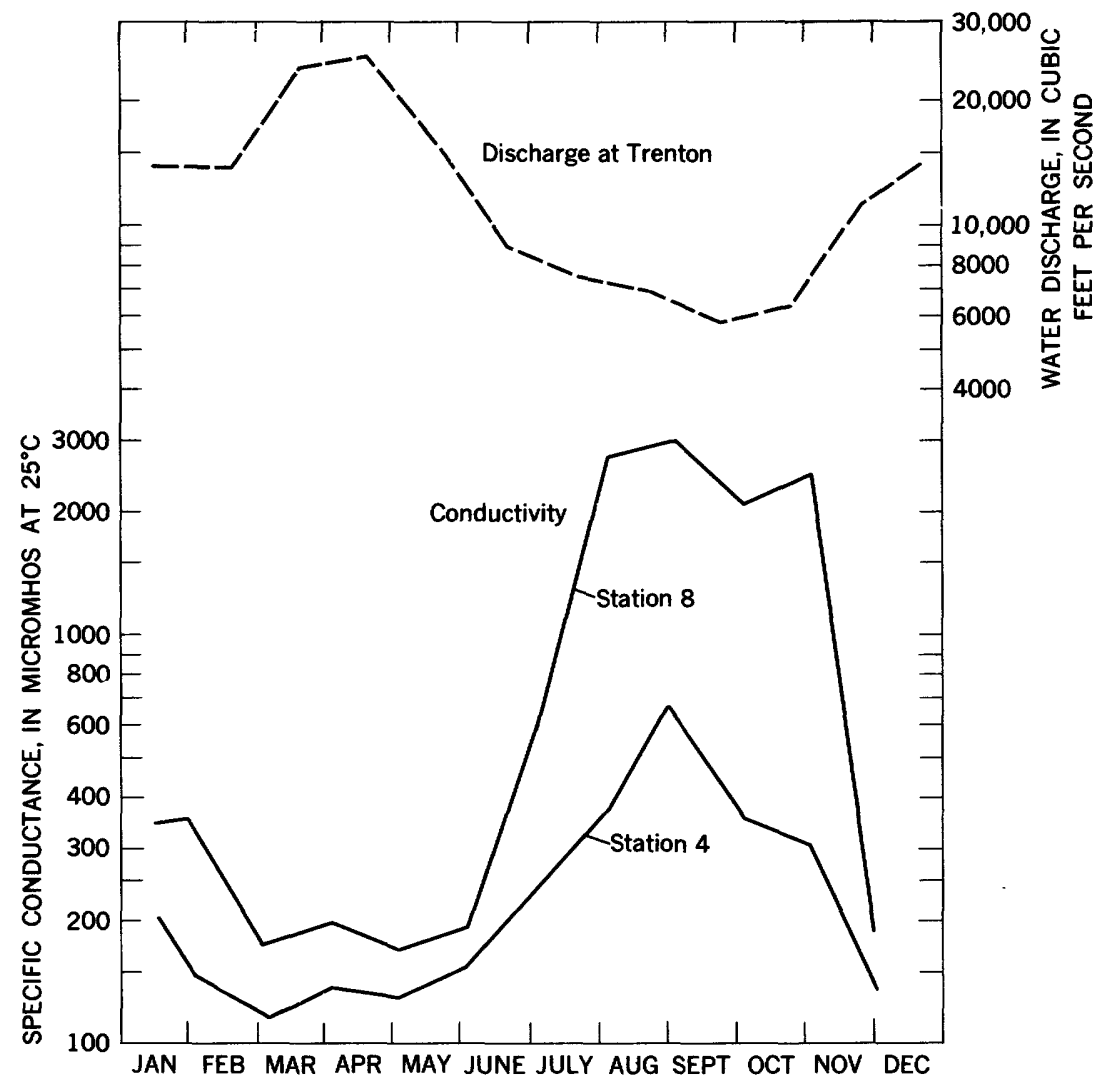

Figdre 14.-Monthly mean conductivity of water in Delaware River at Benjamin Franklin Bridge (sta. 4) and Marcus Hook (sta. 8), and the mean monthly water discharge at Trenton, 1954.

brought into the estuary largely in the river water entering at the head of the tide at Trenton. In March, April, and May the river water at Trenton contains 50-90 ppm of dissolved solids most of the time, whereas the concentration at Marcus Hook during these months averages from 100 to $125 \mathrm{ppm}$. In August and September, when the dissolved-solids concentration at Trenton is generally $70-145 \mathrm{ppm}$, the concentration at Marcus Hook averages about $800 \mathrm{ppm}$; however, the greatest quantities of dissolved solids are carried by the river at Trenton in March and April, when the streamflow is high, and lesser quantities are transported in August and September, when the rate of flow into the estuary is generally much less.

The increase in dissolved-solids concentration between Trenton and Marcus Hook is due in small part to added industrial and municipal 


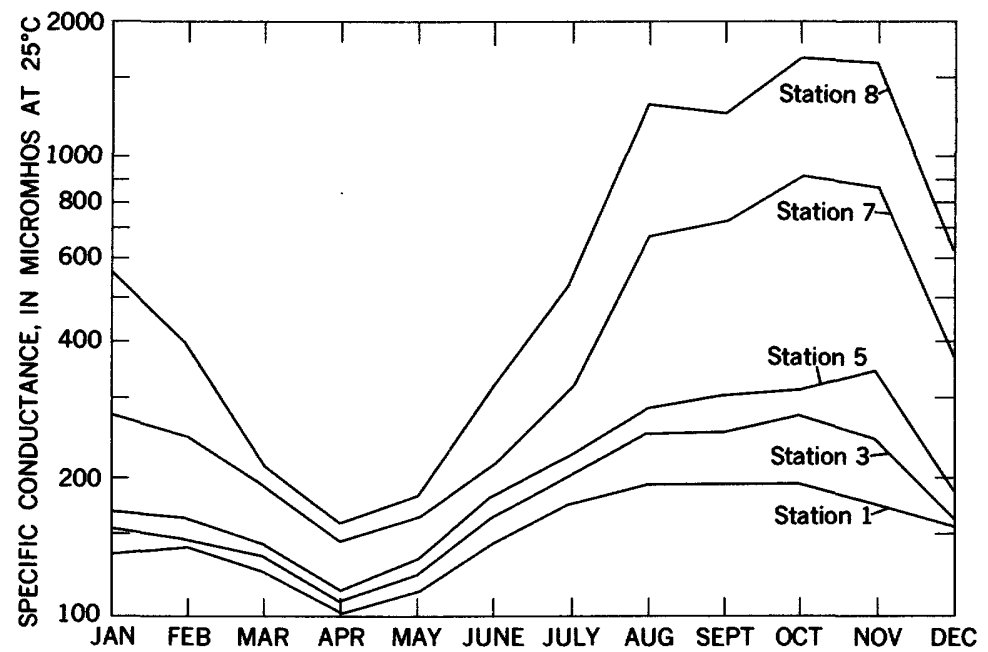

Figure 15.-Mean monthly conductivity of water in Delaware River between Bristol and Marcus Hook, 1949-63. See figure 1 for location of stations $1,3,5,7$, and 8 .

wastes, but mostly to sea water brought upstream by tidal action. That a relation exists may be shown by comparing the composition of the dissolved solids in the water at Marcus Hook with that of the dissolved solids at Trenton and in ocean water. In table 5 the composition of the dissolved solids in river water at Trenton and in estuary water at Marcus Hook are compared to ocean water in terms of the ratios, by weight, of chloride to sulfate, chloride to magne-

TABLE 5.-Comparison of ratios of dissolved solids in Delaware River at Trenton and Marcus Hook with ratios of dissolved solids in ocean water

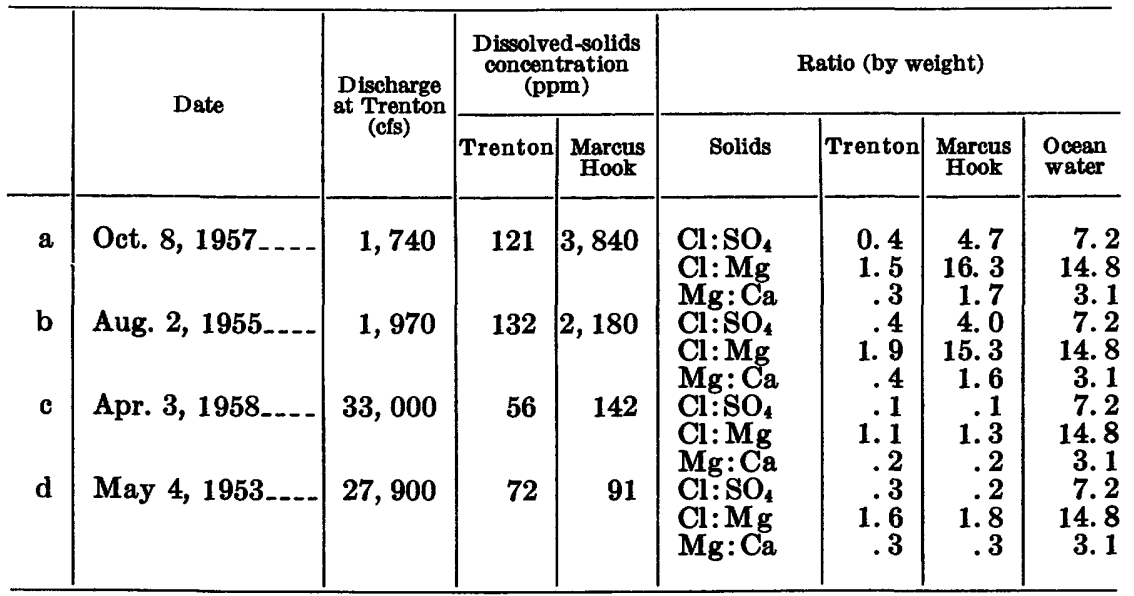




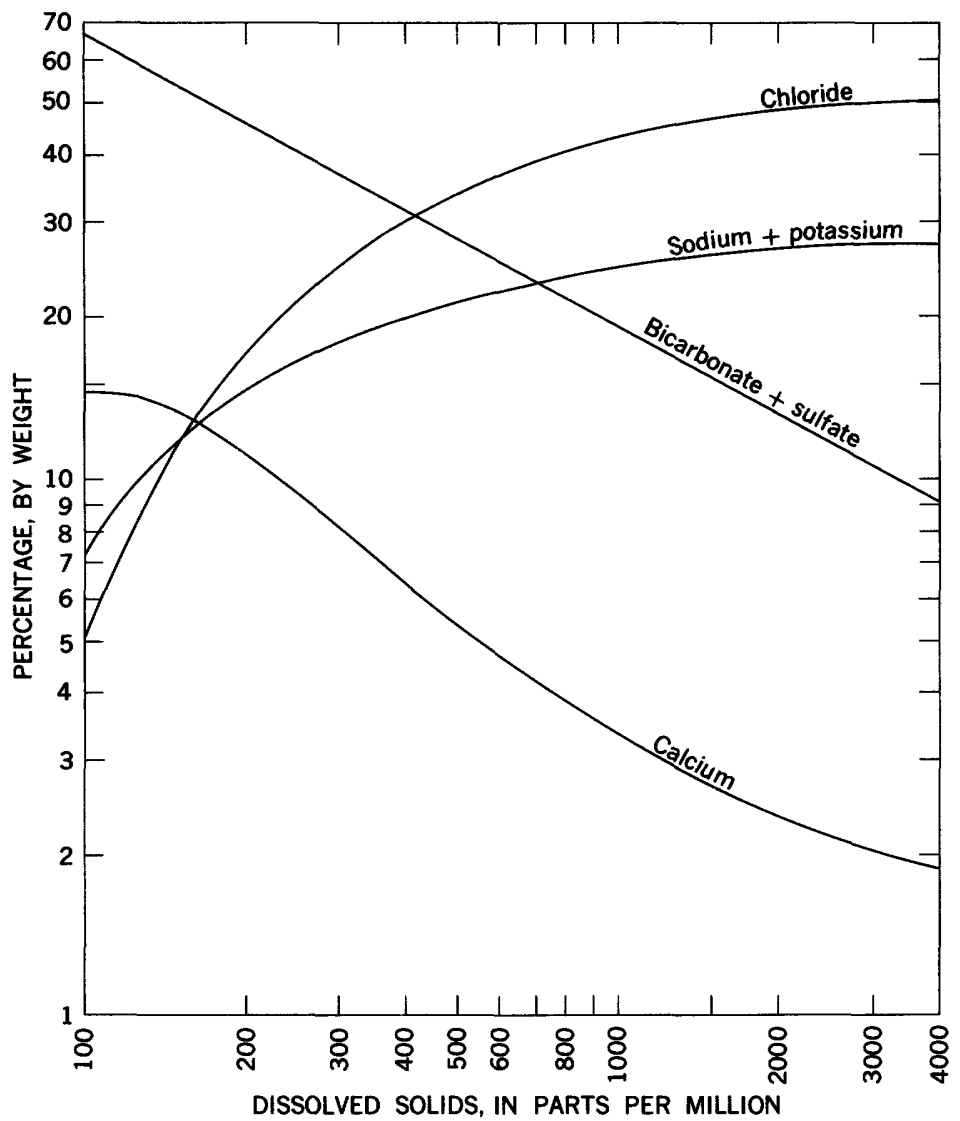

Figore 16.- Relation between concentration and composition of dissolved solids in Delaware River water between Bristol and Marcus Hook, 1950-62.

sium, and magnesium to calcium. At low flow the ratios at Marcus Hook (table 5), items a and $b$ are much more like those for ocean water than for fresh water (Trenton), and this similarity indicates that the increase in salinity between Trenton and Marcus Hook is largely due to the admixture of ocean water with the fresh river water.

At high fresh-water discharge rates, there is less mixing with sea water in this lower reach of the river, because of the flushing effect of the fresh water. This fact is evident from items $c$ and $d$ in table 5. Thus, at high flows the dissolved solids at Marcus Hook have nearly the same composition as those in the fresh water at Trenton. At low flows the composition of the dissolved solids in Delaware River water approaches that of the dissolved solids in ocean water. 


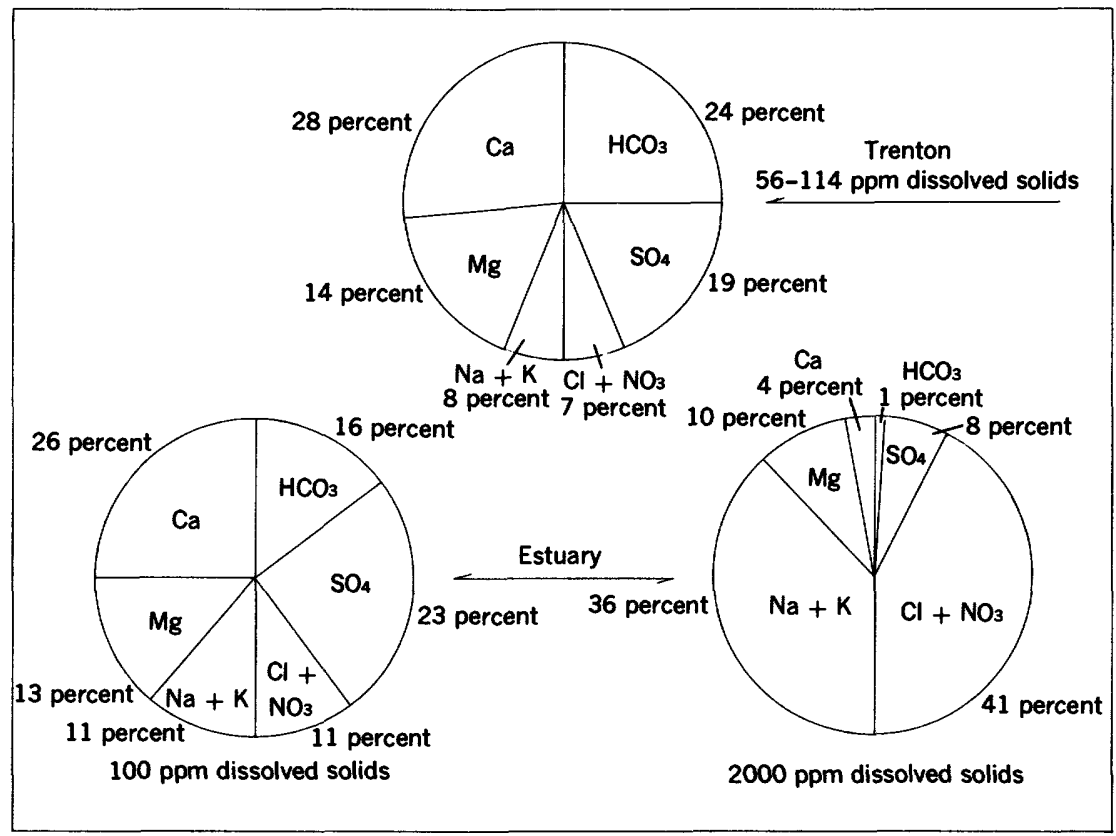

Frgure 17.-Typical composition of dissolved solids in the Delaware River and estuary, by percentage of chemical equivalents.

\section{CHLORIDE}

The annual mean chloride concentration at Marcus Hook varied from 19 to $663 \mathrm{ppm}$, and at Burlington-Bristol Bridge from 5.1 to $9.0 \mathrm{ppm}$ (fig. 18). The highest chloride concentrations in the river below Philadelphia were experienced in 1953, 1954, 1957, and 1963. Salinity incursions may also be described in terms of the maximum salinity each year (fig. 19) or, with more significance for the user of water, in terms of the number of days each year during which a given salinity is reached or exceeded at some point in the river. Table 6 shows the number of days each year when the average chloride concentration exceeded $400 \mathrm{ppm}$ at Marcus Hook, and the daily maximum chloride concentration exceeded $50 \mathrm{ppm}$ at Bridesburg, Pa., and $400 \mathrm{ppm}$ at Chester, Pa. Again the years of greatest salt-water incursion were $1949,1953,1954,1957$, and 1963 . In each of these 5 years (except in 1953), the annual flow was below the average; however, the annual flow was below average in 1950, 1955, 1959,1961 , and 1962 also, but the chloride concentration was not unusually high in these years. The monthly discharge of fresh water at Trenton was below average in each of the months from June to October in 1949, 1953, 1954, 1957, and 1963, and also in 1962. 


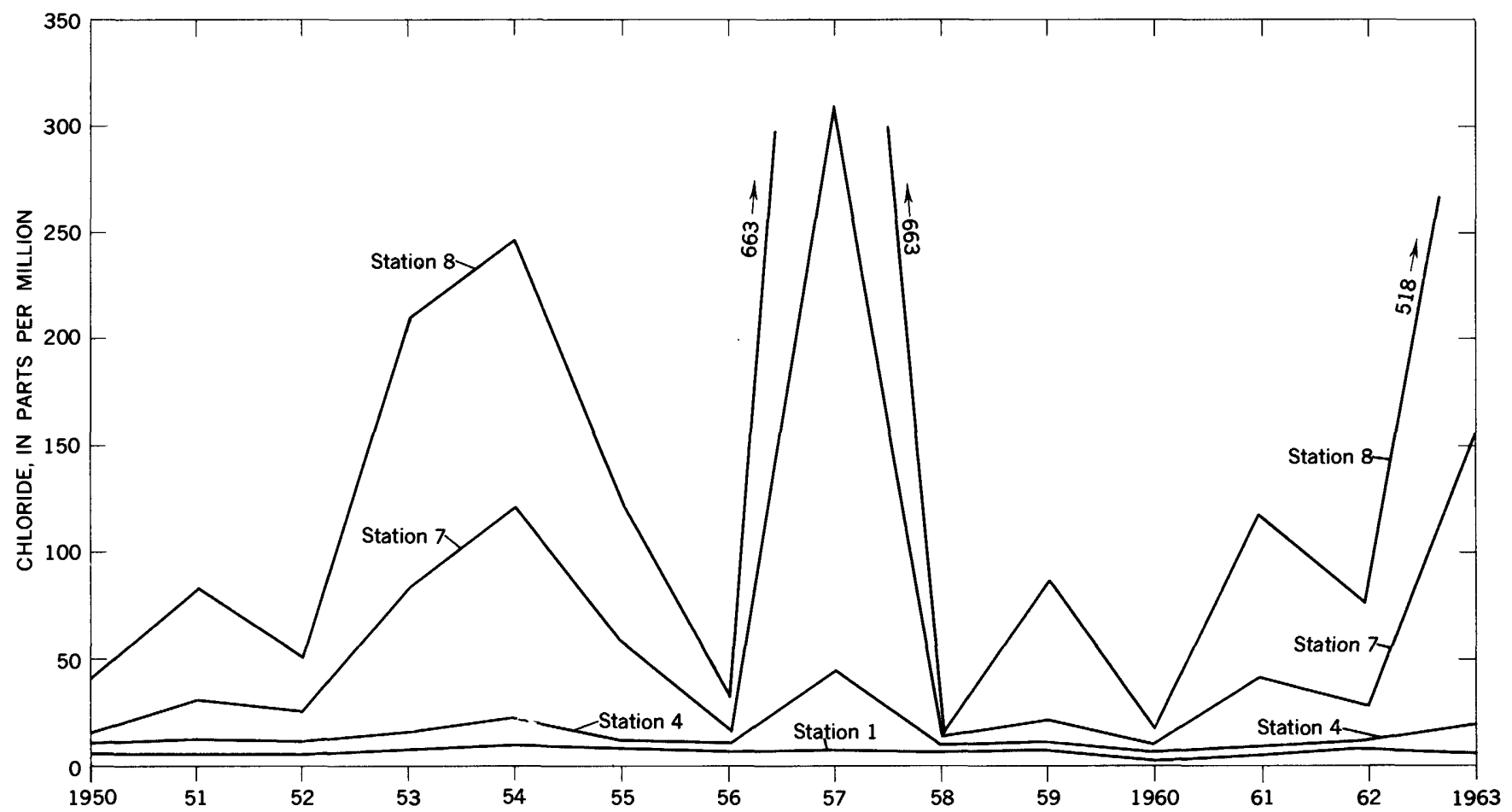

资

FigdRe 18.-Annual mean chloride concentrations in Delaware River between Bristol and Marcus Hook, $1950-63$. See figure 1 for location of stations $1,4,7$, and 8 . 


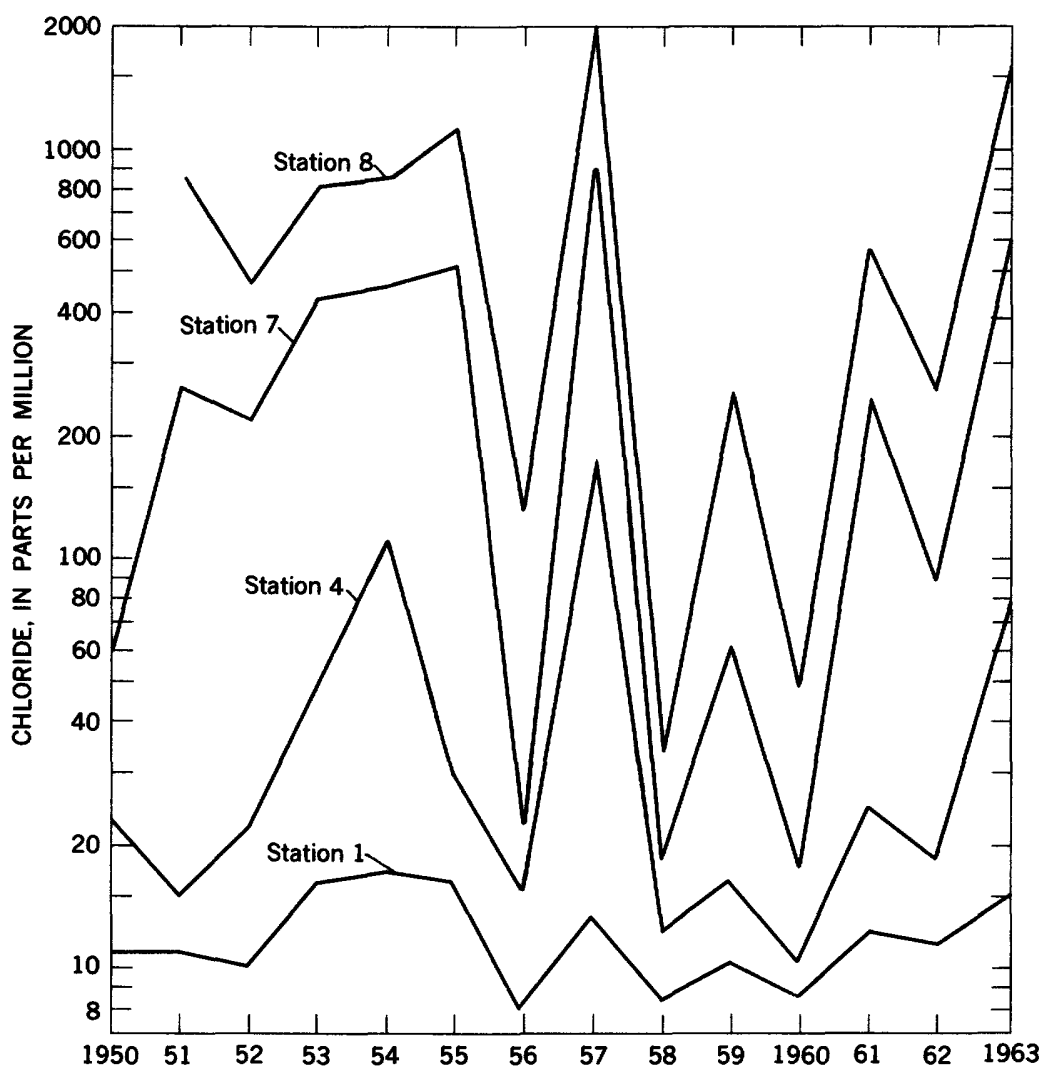

Fiadre 19.-Annual maximum chloride concentrations in Delaware River between Bristol and Marcus Hook, 1950-63. See figure 1 for location of stations $1,4,7$, and 8 .

The frequency with which various chloride concentrations in the estuary occurred during 1950-63 is shown in figures 20 and 21 . For example, a chloride concentration of $10 \mathrm{ppm}$ or greater occurred 15 percent of the time at Burlington-Bristol Bridge, 45 percent of the time at Benjamin Franklin Bridge, 56 percent of the time at Eddystone, and 74 percent of the time at Marcus Hook. A chloride concentration of $100 \mathrm{ppm}$ or greater was observed at Benjamin Franklin Bridge only 2 percent of the time, at Eddystone 9 percent of the time, and at Marcus Hook 24 percent of the time.

The mean monthly. chloride concentrations during 1950-62 are plotted in figure 22. As with dissolved solids and conductivity (fig. 15), the chloride concentrations are least in December to May and greatest in August to November. 
TABLE 6.-Number of days each year in which selected chloride concentrations were exceeded for a salt-water invasion, Delaware River at Bridesburg, Chester, and Marcus Hook, Pa., and average June to October discharge at Trenton, N.J., for each year.

[Chloride data furnished by Rohm and Haas Co. for Bridesburg; Scott Paper Co. for Chester; Sun Oil Co. for Marcus Hook]

\begin{tabular}{|c|c|c|c|c|}
\hline \multirow{3}{*}{ Year } & \multicolumn{2}{|c|}{$\begin{array}{l}\text { Days daily maximum } \\
\text { chloride concentration } \\
\text { exceeded- }\end{array}$} & \multirow{3}{*}{$\begin{array}{c}\begin{array}{c}\text { Days daily av- } \\
\text { erage chloride } \\
\text { concentration } \\
\text { exceeded- }\end{array} \\
400 \mathrm{ppm} \\
\begin{array}{c}\text { Marcus Hook, } \\
\mathrm{Pa.}^{2}\end{array}\end{array}$} & \multirow{3}{*}{$\begin{array}{c}\text { A verage daily } \\
\text { discharge at } \\
\text { Trenton, N.J., } \\
\text { June to October } \\
\text { (cfs) }\end{array}$} \\
\hline & $50 \mathrm{ppm}$ & $400 \mathrm{ppm}$ & & \\
\hline & $\begin{array}{l}\text { Bridesburg, } \\
\text { Philadelphia, } \\
\text { Pa.1 }\end{array}$ & Chester, Pa.1 & & \\
\hline $\begin{array}{l}1949 \\
19501 \\
1952 \\
1953 \\
19556\end{array}$ & $\begin{array}{r}0 \\
0 \\
0 \\
9 \\
32 \\
0 \\
0 \\
86 \\
0 \\
0 \\
0 \\
0 \\
0 \\
16\end{array}$ & \begin{tabular}{r}
111 \\
9 \\
6 \\
11 \\
\hdashline 119 \\
29 \\
0 \\
132 \\
0 \\
0 \\
0 \\
21 \\
13 \\
122
\end{tabular} & $\begin{array}{r}120 \\
17 \\
22 \\
17 \\
98 \\
128 \\
36 \\
0 \\
144 \\
0 \\
0 \\
0 \\
35 \\
31\end{array}$ & $\begin{array}{r}3,522 \\
6,382 \\
6,621 \\
9,103 \\
3,709 \\
2,996 \\
14,781 \\
6,680 \\
2,771 \\
5,369 \\
4,954 \\
10,277 \\
4,990 \\
3,210 \\
3,009\end{array}$ \\
\hline
\end{tabular}

1 Bridesburg and Chester dara are based on samples collected at high tides.

2 Marcus Hook data represent the analyses of daily composites of hourly samples (compiled by Frederick Schaefer for report of the River Master for the year ending Nov. 30, 1963).

\section{DISSOLVED OXYGIN}

The annual mean dissolved-oxygen concentrations at five locations in the Delaware estuary are plotted in figure 23. Dissolved oxygen decreases from Bristol to Marcus Hook, the sharpest decrease occurring between Torresdale and Lehigh Avenue. Minimum dissolvedoxygen concentrations are plotted in figure 24 . The very low minima in 1950-53 have not been repeated in later years. In general, the lowest concentrations are found near Wharton Street, and a slight recovery is made between there and Marcus Hook. Figure 25 is a frequency plot of dissolved oxygen in percent saturation. Five percent of the samples at Marcus Hook, 15 percent of those at Benjamin Franklin Bridge, 62 percent of those at Torresdale, and 76 percent of those at Bristol were at least 75 percent saturated. All these samples were taken in the daytime, and the average daily dissolvedoxygen concentrations very possibly were lower than those represented by the figures tabulated and plotted. For example, upstream at Trenton the dissolved-oxygen concentration varies diurnally as a 


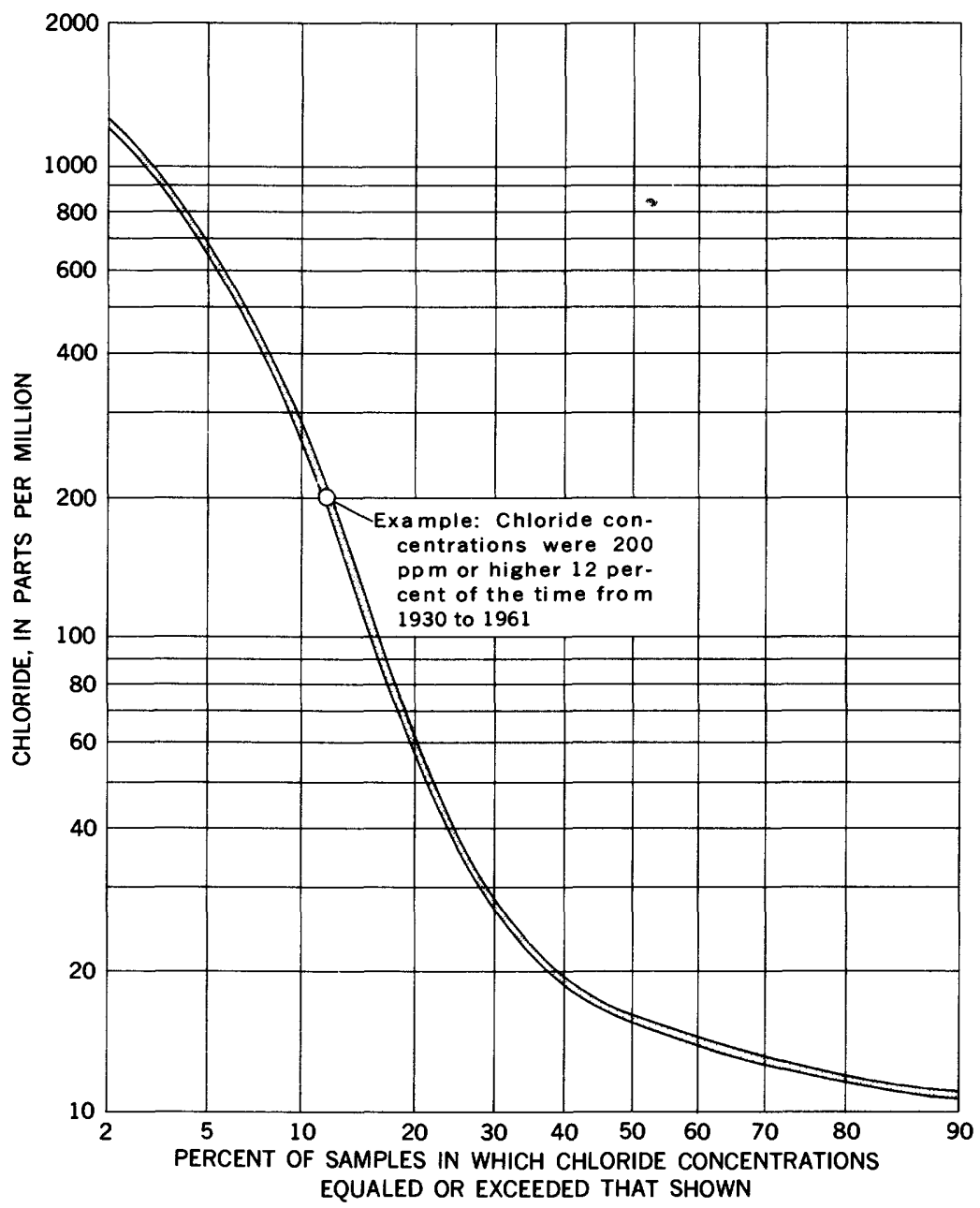

Figure 20.-Frequency of various chloride concentrations in Delaware River at Chester, Pa., 1930-61.

result of photosynthesis. The minimum daily dissolved oxygen, about 6-8 ppm, occurs between 5:00 and 6:00 a.m. in the morning. During daylight hours the dissolved-oxygen concentration increases to as high as $14 \mathrm{ppm}$.

In recent years, dissolved oxygen in the estuary has been measured by instruments that record continuously so that daily average concentrations could be obtained. Table 7 shows the frequency with which low values of dissolved oxygen have been experienced at three dissolved-oxygen recorders on the estuary. 
DELAWARE RIVER WATER, BRISTOL TO MARCUS HOOK O29

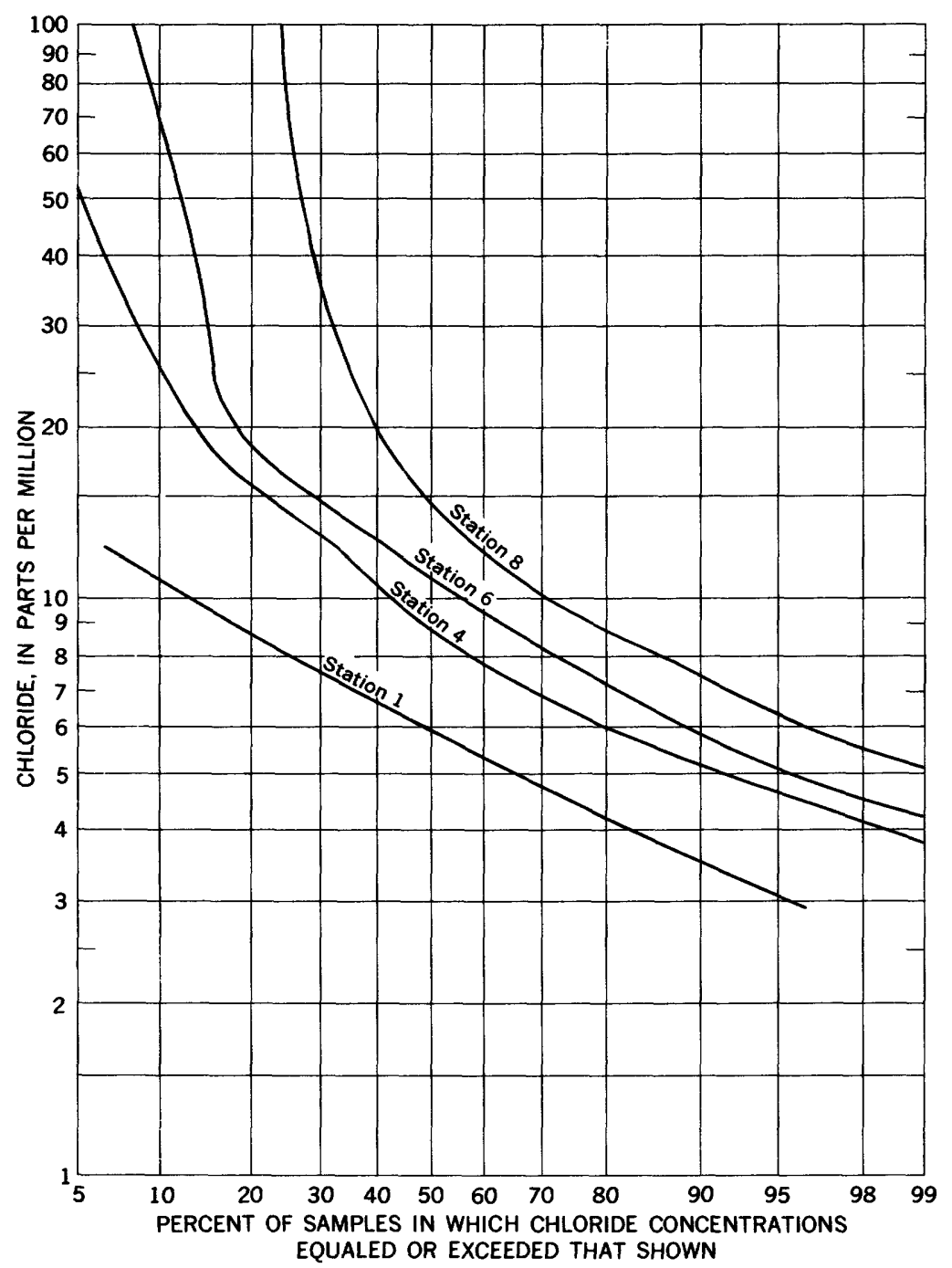

Frgure 21.-Frequency of various chloride concentrations in Delaware

River, 1950-62. See figure 1 for location of stations $1,4,6$, and 8 .

Figure 26 shows the monthly variation in dissolved-oxygen concentration during 1950-63. The concentration is lowest in those months when the water temperature is highest, because less oxygen dissolves in warm water than in cold water and because the biochemical reactions that consume oxygen occur at accelerated rates at higher temperatures. 
TABLE 7.-Number of days dissolved-oxygen concentration was less than 1 and 3 ppm at three dissolved-oxygen recorders in the Delaware River, March 1961December 1963

\begin{tabular}{|c|c|c|c|c|c|c|}
\hline & \multicolumn{6}{|c|}{ Number of days } \\
\hline & \multicolumn{3}{|c|}{ Concentration $<1 \mathrm{ppm}$} & \multicolumn{3}{|c|}{ Concentration $<3 \mathrm{ppm}$} \\
\hline & Torresdale & $\begin{array}{c}\text { Benjamin } \\
\text { Franklin } \\
\text { Bridge }\end{array}$ & Chester & Torresdale & $\begin{array}{c}\text { Benjamin } \\
\text { Franklin } \\
\text { Bridge }\end{array}$ & Chester \\
\hline $\begin{array}{l}\text { March. } \\
\text { April._. } \\
\text { May } \\
\text { June-1961 } \\
\text { July } \\
\text { August } \\
\text { September } \\
\text { October } \\
\text { November } \\
\text { December }\end{array}$ & $\begin{array}{l}\mathbf{0} \\
\mathbf{0} \\
\mathbf{0} \\
\mathbf{0} \\
\mathbf{0} \\
\mathbf{0} \\
\mathbf{0} \\
\mathbf{0} \\
\mathbf{0} \\
\mathbf{0}\end{array}$ & $\begin{array}{r}\mathbf{0} \\
\mathbf{0} \\
\mathbf{0} \\
26 \\
31 \\
31 \\
30 \\
31 \\
23 \\
0\end{array}$ & 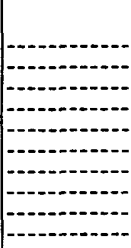 & $\begin{array}{r}0 \\
0 \\
0 \\
5 \\
22 \\
17 \\
7 \\
0 \\
0 \\
0\end{array}$ & $\begin{array}{r}\mathbf{0} \\
\mathbf{0} \\
\mathbf{9} \\
\mathbf{3 0} \\
\mathbf{3 1} \\
\mathbf{3 1} \\
\mathbf{3 0} \\
\mathbf{3 1} \\
\mathbf{2 7} \\
\mathbf{0}\end{array}$ & $\mid$\begin{tabular}{l}
-1 \\
\hdashline-1
\end{tabular} \\
\hline $\begin{array}{l}\text { January } 1962 \\
\text { February } \\
\text { March } \\
\text { April. } \\
\text { May. } \\
\text { June } \\
\text { July } \\
\text { August } \\
\text { September. } \\
\text { October } \\
\text { November } \\
\text { December }\end{array}$ & $\begin{array}{r}\mathbf{0} \\
0 \\
\mathbf{0} \\
\mathbf{0} \\
\mathbf{0} \\
\mathbf{1 4} \\
\mathbf{1 0} \\
\mathbf{9} \\
\mathbf{0} \\
\mathbf{0} \\
\mathbf{0} \\
\mathbf{0}\end{array}$ & $\begin{array}{r}\mathbf{0} \\
\mathbf{0} \\
\mathbf{0} \\
\mathbf{0} \\
\mathbf{2 6} \\
\mathbf{3 0} \\
\mathbf{3 1} \\
\mathbf{3 1} \\
\mathbf{3 0} \\
\mathbf{2 9} \\
\mathbf{2} \\
\mathbf{0}\end{array}$ & $\begin{array}{r}\mathbf{0} \\
\mathbf{0} \\
\mathbf{0} \\
\mathbf{0} \\
\mathbf{2 9} \\
\mathbf{2 7} \\
\mathbf{3 1} \\
\mathbf{3 1} \\
\mathbf{3 0} \\
\mathbf{2 6} \\
\mathbf{7} \\
\mathbf{0}\end{array}$ & \begin{tabular}{r|}
$\mathbf{0}$ \\
$\mathbf{0}$ \\
$\mathbf{0}$ \\
$\mathbf{0}$ \\
$\mathbf{2}$ \\
$\mathbf{3 0}$ \\
$\mathbf{2 6}$ \\
$\mathbf{3 1}$ \\
$\mathbf{2 4}$ \\
$\mathbf{0}$ \\
$\mathbf{0}$ \\
$\mathbf{0}$
\end{tabular} & $\begin{array}{r}\mathbf{0} \\
\mathbf{0} \\
\mathbf{0} \\
\mathbf{1} \\
\mathbf{3 1} \\
\mathbf{3 0} \\
\mathbf{3 1} \\
\mathbf{3 1} \\
\mathbf{3 0} \\
\mathbf{3 1} \\
\mathbf{5} \\
\mathbf{0}\end{array}$ & $\begin{array}{r}\mathbf{0} \\
0 \\
0 \\
2 \\
31 \\
30 \\
31 \\
31 \\
30 \\
31 \\
13 \\
0\end{array}$ \\
\hline $\begin{array}{l}\text { January } \\
\text { February } \\
\text { March } \\
\text { April } \\
\text { May } \\
\text { June } \\
\text { July } \\
\text { August } \\
\text { September } \\
\text { October } \\
\text { November } \\
\text { December }\end{array}$ & $\begin{array}{l}\mathbf{0} \\
\mathbf{0} \\
\mathbf{0} \\
\mathbf{0} \\
\mathbf{0} \\
\mathbf{2} \\
\mathbf{0} \\
\mathbf{0} \\
\mathbf{0} \\
\mathbf{0} \\
\mathbf{0}\end{array}$ & $\begin{array}{r}\mathbf{0} \\
\mathbf{0} \\
0 \\
\mathbf{0} \\
21 \\
30 \\
31 \\
31 \\
30 \\
\mathbf{3 1} \\
\mathbf{2 6} \\
\mathbf{0}\end{array}$ & \begin{tabular}{r|}
$\mathbf{0}$ \\
$\mathbf{0}$ \\
0 \\
$\mathbf{0}$ \\
$2 \mathbf{2}$ \\
$\mathbf{2 9}$ \\
$\mathbf{3 1}$ \\
$\mathbf{3 1}$ \\
$\mathbf{3 0}$ \\
$\mathbf{3 1}$ \\
$\mathbf{2 3}$ \\
$\mathbf{3}$
\end{tabular} & $\begin{array}{r}\mathbf{0} \\
\mathbf{0} \\
\mathbf{0} \\
\mathbf{0} \\
\mathbf{0} \\
\mathbf{2 1} \\
\mathbf{2 5} \\
\mathbf{1 4} \\
\mathbf{9} \\
\mathbf{3} \\
\mathbf{0} \\
\mathbf{0}\end{array}$ & $\begin{array}{r}\mathbf{0} \\
\mathbf{0} \\
\mathbf{0} \\
\mathbf{6} \\
\mathbf{3 1} \\
\mathbf{3 0} \\
\mathbf{3 1} \\
\mathbf{3 1} \\
\mathbf{3 0} \\
\mathbf{3 1} \\
\mathbf{3 0} \\
\mathbf{8}\end{array}$ & $\begin{array}{r}\mathbf{0} \\
\mathbf{0} \\
\mathbf{0} \\
\mathbf{7} \\
\mathbf{3 0} \\
\mathbf{3 0} \\
\mathbf{3 1} \\
\mathbf{3 1} \\
\mathbf{3 0} \\
\mathbf{3 1} \\
\mathbf{3 0} \\
\mathbf{1 4}\end{array}$ \\
\hline
\end{tabular}

Additional information on dissolved-oxygen concentrations is shown in figure 27 . The average dissolved-oxygen concentration and the range of concentrations is plotted for stations (a) upstream from central Philadelphia, (b) near central Philadelphia, and (c) downstream from central Philadelphia, for four periods of the year. The data show that the concentration of dissolved oxygen is lowest in June to September and highest in December to March, that it decreases as the water flows downstream past Philadelphia, and that it decreases still further in December to May as the water flows on to Marcus Hook.

\section{SUSPENDFD SEDIMENT}

The yearly changes in suspended-sediment concentration are shown in figure 28. The determinations shown in this figure are the ratio 


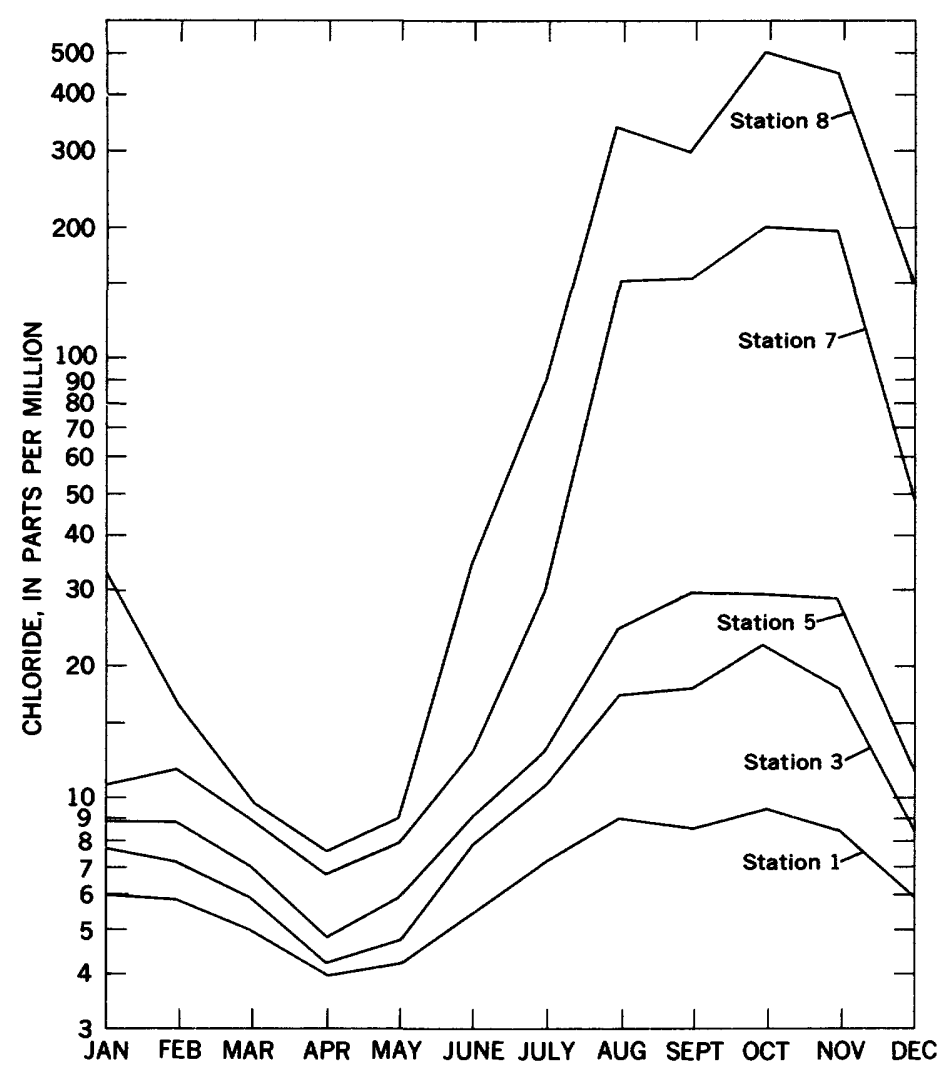

Figure 22.-Mean monthly chloride concentrations in Delaware River, 1950-62. See figure 1 for location of stations 1, 3, 5, 7, and 8.

of dry weight of sediment to the total weight of the water-sediment sample as measured on composite samples at each station. Although the sediments are composite, the determinations are adequate to show gross changes in suspended-sediment concentration; however, they should not be used to calculate the load of sediment transported, for no consideration has been given to the differences in rates of flow in different parts of the cross sections.

Until 1957 the sediment concentration increased from Bristol downstream to Marcus Hook. The change in this situation after 1959 is probably related to channel-dredging activities in the river upstream from the Benjamin Franklin Bridge. At times the increase in sediment was evident in the muddy appearance of the river 

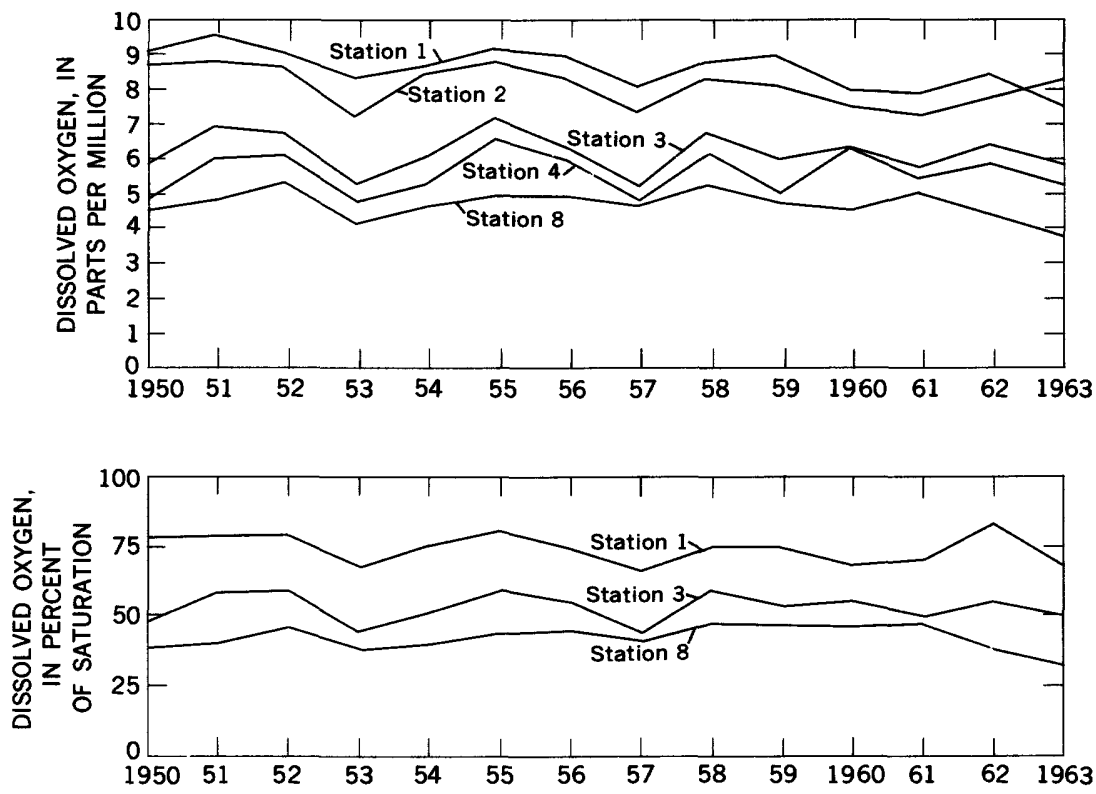

Frgdre 23.-Annual mean dissolved-oxygen concentrations in Delaware River, 1950-63. See figure 1 for location of stations $1,2,3,4$, and 8 .
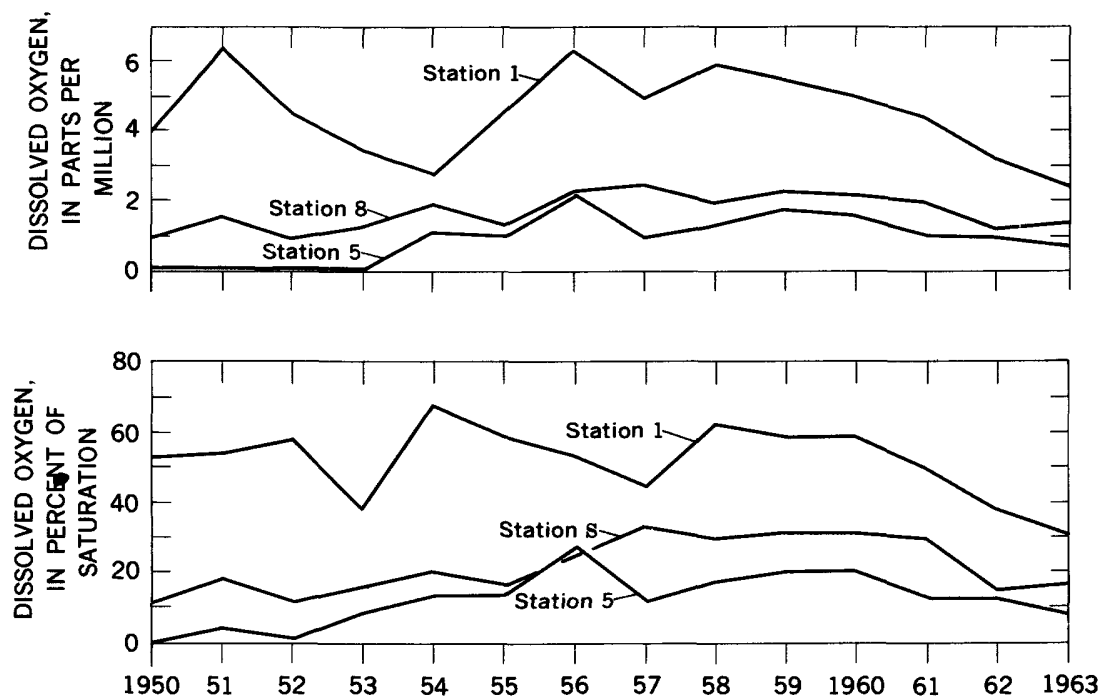

Fradre 24.-Annual minimum dissolved-oxygen concentrations in Delaware River, 1950-63. See figure 1 for location of stations 1,5 , and 8 . 
at Philadelphia. Monthly sediment concentrations shown in figure 29 are based on data from August 1949 to December 1959. Higher concentrations generally occur in the months of higher streamflow, when the water is more turbulent than in the low-flow months.

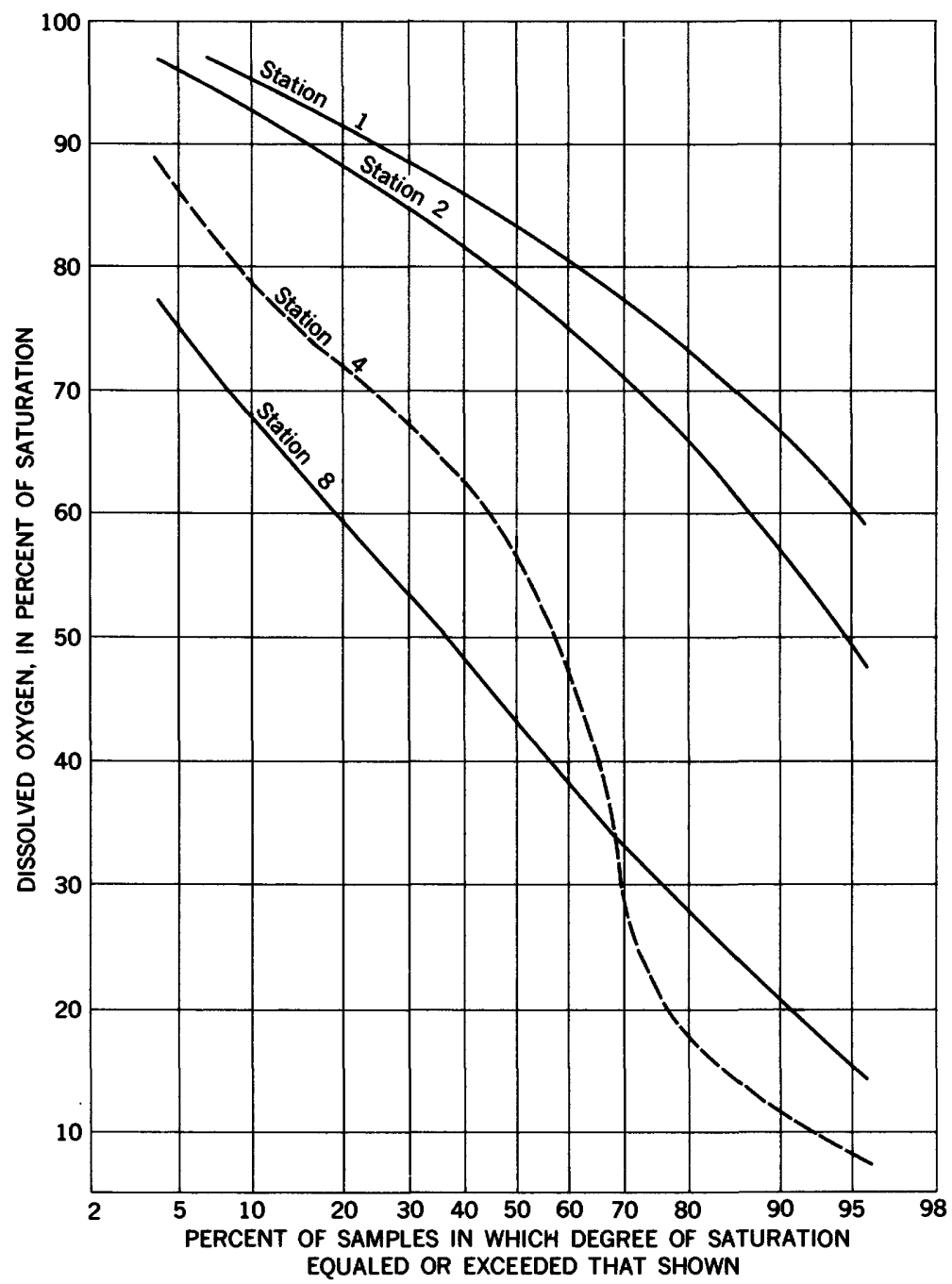

Frgure 25.-Frequency of given dissolved-oxygen concentrations in Delaware River, 1950-63, in percent saturation. See figure 1 for location of stations $1,2,4$, and 8 . 


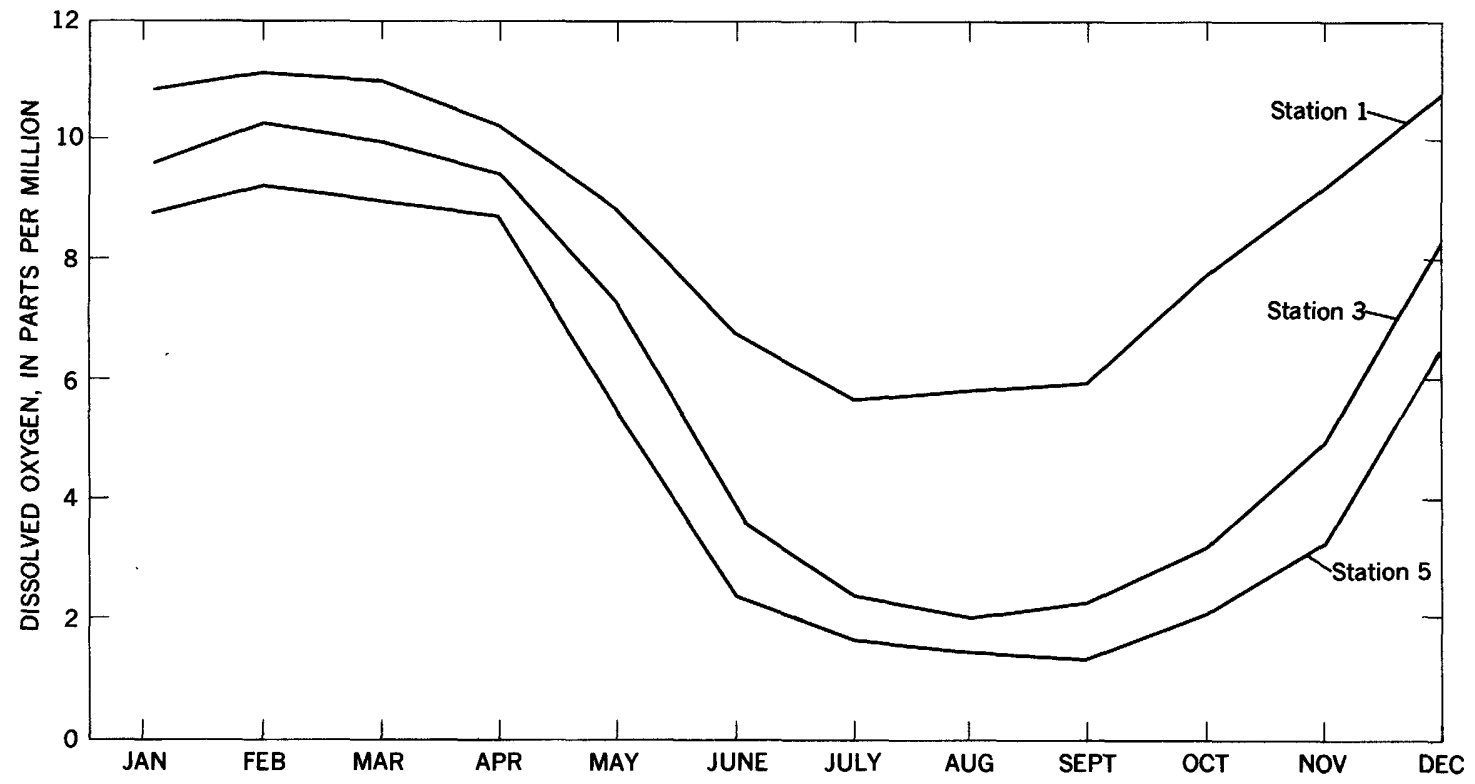




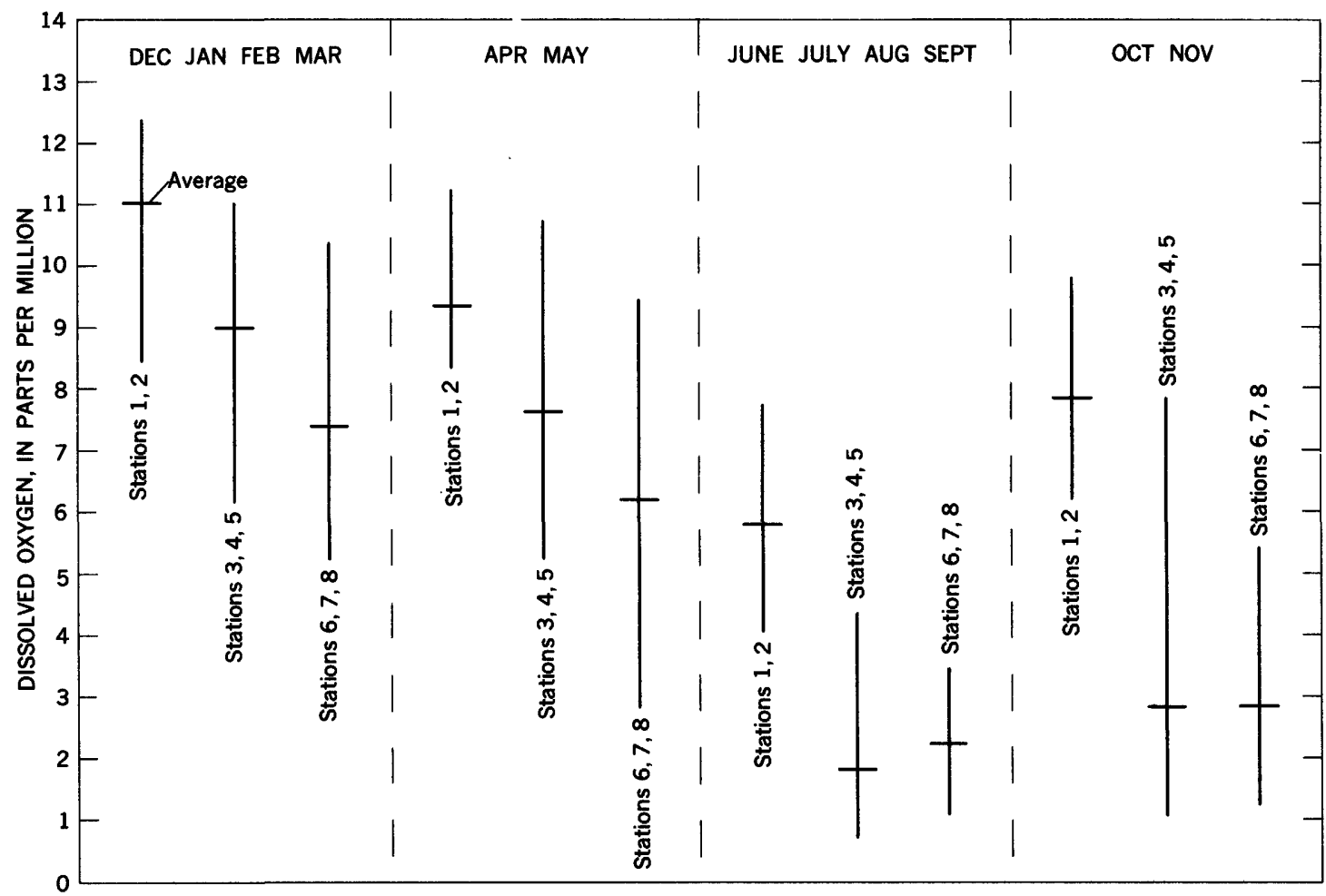

Figure 27.-Average dissolved-oxygen concentration and range of central 80 percent of concentrations at selected groups of stations in each of four periods of the year, 1950-63. See figure 1 for location of stations. 


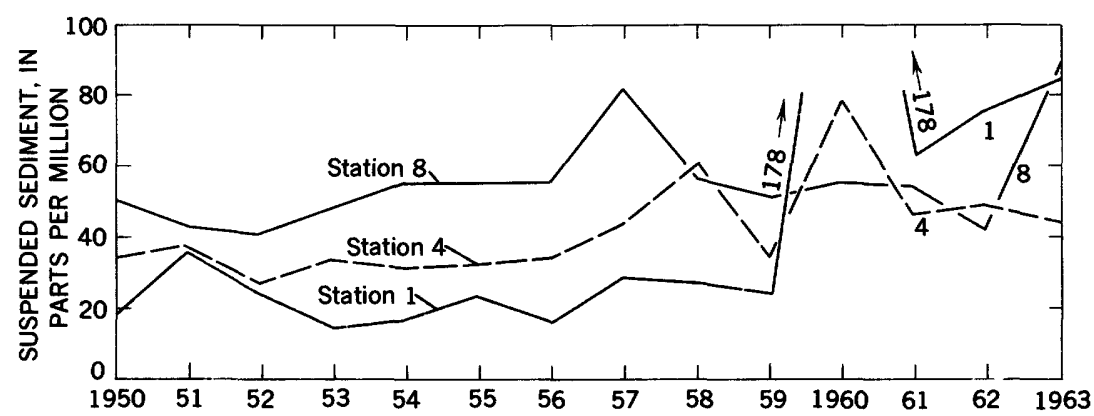

Figure 28.-Annual mean suspended-sediment concentrations in Delaware River, 1950-63. See figure 1 for location of stations 1,4 , and 8 .

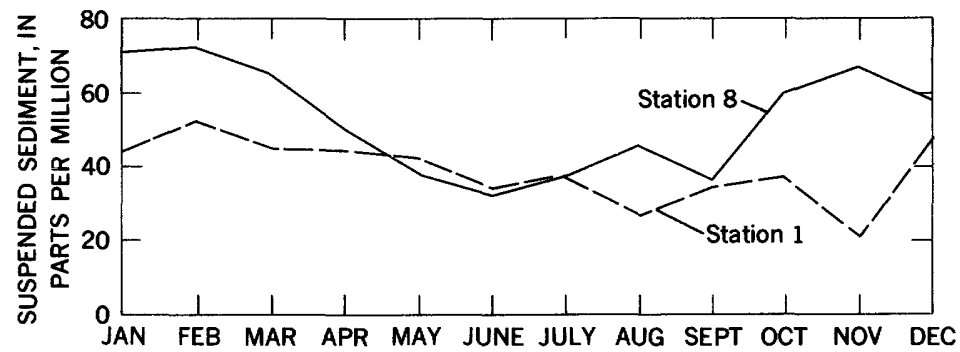

Figure 29.-Mean monthly suspended-sediment concentrations in Delaware River at Bristol and Marcus Hook, 1950-62. See figure 1 for location of stations 1 and 8 .

\section{TABULAR SUMMARIES OF WATER-QUALITY CHARACTERISTICS}

The monthly analyses of the 14-year period are summarized in tables 9, 10, and 11. Each table contains eight divisions, one for each of the eight sampling locations; these divisions are identified by title and by the number used to identify the sampling location in figure 1 and in table 1. For example, table 9 (3) gives a summary for station 3, Lehigh Avenue, Philadelphia.

Table 8 gives physical descriptions of each of the eight sampling stations. The locations are given in distances upstream or downstream from Allegheny Avenue, Philadelphia, Pa., measured along the centerline of the navigation channel in units of 1,000 feet. Locations upstream from Allegheny Avenue are labeled ( - ), and those downstream $(+)$. Thus, the Bristol-Burlington Bridge station is 79,200 feet upstream from Allegheny Avenue. Details of each sampling location are given in the maps referred to in table 8. These maps can be obtained from the Corps of Engineers, Philadelphia 
District, and from the U.S. Coast and Geodetic Survey. Included in the physical description is the "Accumulated volume" for each station, that is, the quantity of water to fill the river at midtide level, from head of tide to the sampling station.

Table 9 is a frequency distribution for selected percentile groups of $\mathrm{pH}$, specific conductance, chloride, water temperature, and dissolved oxygen for each of the eight sampling stations. For example, table 9 (1) shows that at Bristol-Burlington Bridge cross section the $\mathrm{pH}$ ranged from 6.2 to 7.8 and that the median $\mathrm{pH}$ was 6.9 (that is, that the $\mathrm{pH}$ was less than 6.9 as frequently as it was greater).

Table 10 gives the annual maximum, mean, and minimum measurements of specific conductance, chloride, suspended sediment, water temperature, and dissolved oxygen; and for $\mathrm{pH}$, the annual maximum, median, and minimum. Monthly maximum, mean (median for $\mathrm{pH}$ ), and minimum measurements for the same characteristics are listed in table 11.

\section{TABLE 8.-Physical description of sampling locations}

\section{Bristol (Pa.)-Burlington (N.J.) Bridge station}

Location: In Devlin navigation range 1,300 $\mathrm{ft}$ upstream from bridge on a line from Pennsylvania bank (right) through channel station -79.2 to Lehigh range light on New Jersey bank (left), approximately 15 miles downstream from head of tide at Trenton, N.J.

SAMPLING POINTS:

Right side: $200 \mathrm{ft}$ from Pennsylvania bank on line with No. 2 suspender which is to the right of right tower of bridge.

Right center: $475 \mathrm{ft}$ from Pennsylvania bank on line with right tower and buoy $\mathrm{C}-43$.

Center: $825 \mathrm{ft}$ from Pennsylvania bank on line $40 \mathrm{ft}$ left of centerline of bridge. Left center: 1,050 ft from Pennsylvania bank on line with left tower of bridge. Left side: 1,275 ft from Pennsylvania bank (25 ft from New Jersey and Lehigh range light).

Drainage ARea: 7,160 sq mi.

Accumulated volume: 1,635 million $\mathrm{cu} f \mathrm{ft}$, below the head of tide at Trenton, N.J. REFERENCE MAPS:

Corps of Engineers, Delaware River, Burlington to Bristol, file No. 25006.

U.S. Coast and Geodetic Survey, Delaware River, Philadelphia, Pa., to Trenton, N.J., No. 296.

2. Torresdale, Philadelphia, station

Location: On a line from brick building on bulkhead line at filter plant through channel station -37.0 to New Jersey bank. (Brick building is the site of an inactive water intake for filter plant. Present intake to sedimentation basin is 2,400 ft upstream from sampling location).

SAMPLING POINTS:

Right side: $30 \mathrm{ft}$ from intake building.

Right center: $425 \mathrm{ft}$ from intake building.

Center: $900 \mathrm{ft}$ from intake building.

Left center: $1,400 \mathrm{ft}$ from intake building.

Left side: $1,800 \mathrm{ft}$ from intake building ( $400 \mathrm{ft}$ from New Jersey bank). 
Drainage area: 7,781 sq $\mathrm{mi}$.

Accumulated volume: 3,088 million $\mathrm{cu} f \mathrm{ft}$, below the head of tide at Trenton, N.J. REFERENCE MAPS:

Corps of Engineers, Delaware River, Ten Mile Point to Rancocas River, file No. 25003.

U.S. Coast and Geodetic Survey, Delaware River, Philadelphia, Pa. to Trenton, N.J., No. 296.

3. Lehigh Avenue, Philadelphia, station

Location: On a line midway between piers 14 and 18 Port Richmond Terminal through channel station +5.0 to pierhead line on Petty Island. (Aug. 1949Dec. 1952, $800 \mathrm{ft}$ upstream from here.)

SAMPLING PoInts:

Right side: $50 \mathrm{ft}$ from Pennsylvania pierhead line.

Right center: $500 \mathrm{ft}$ from Pennsylvania pierhead line.

Center: $950 \mathrm{ft}$ from Pennsylvania pierhead line.

Left center: $1,450 \mathrm{ft}$ from Pennsylvania pierhead line.

Left side: 1,850 ft from Pennsylvania pierhead line (50 ft from pierhead line on Petty Island).

Drainage area: 7,935 sq mi.

Accumulated volume: 5,363 million cu $\mathrm{ft}$, below the head of tide at Trenton, N.J.

REFERENCE MAPS:

Corps of Engineers, Delaware River, Cooper Point to Fisher Point, file No. 17112.

U.S. Coast and Geodetic Survey, Delaware River, Philadelphia and Camden waterfronts, No. 280.

\section{Benjamin Franklin Bridge station}

[At one time this was known as the Philadelphia-Camden Bridge station]

Location: On a line $200 \mathrm{ft}$ upstream of bridge from north side of pier 12 North through channel station +14.3 to pierhead line on New Jersey side of river. (Aug. 1949-Dec. 1952, $400 \mathrm{ft}$ upstream from here.)

Sampling Points:

Right side: At Philadelphia pierhead line.

Right center: $425 \mathrm{ft}$ from Philadelphia pierhead line (midway between right bridge abutment and centerline of bridge).

Center: $850 \mathrm{ft}$ from Philadelphia pierhead line (centerline of bridge).

Left center: 1,250 ft from Philadelphia pierhead line (midway between left bridge abutment and centerline of bridge).

Left side: $1,700 \mathrm{ft}$ from Philadelphia pierhead line (on line with right side of left bridge abutment on pierhead line).

Drainage area: 7,993 sq mi.

Accumulated volume: 5,869 million $\mathrm{cu} \mathrm{ft}$, below the head of tide at Trenton, N.J.

REFERENCE MAPS:

Corps of Engineers, Delaware River, Gloucester, N.J., to Cooper Point, file No. 17111.

U.S. Coast and Geodetic Survey, Delaware River, Philadelphia and Camden waterfronts, No. 280.

\section{Wharton Street, Philadelphia, station}

Location: On a line between piers 53 and 55 South, Philadelphia, through channel station +22.6 to coal pier on New Jersey side of river. (Aug. 1949-Dec. 1952, $250 \mathrm{ft}$ downstream from here.) 


\section{PaMPLing POINTS:}

Right side: $50 \mathrm{ft}$ from Philadelphia pierhead line.

Right center: $500 \mathrm{ft}$ from Philadelphia pierhead line.

Center: $1,000 \mathrm{ft}$ from Philadelphia pierhead line.

Left center: $1,500 \mathrm{ft}$ from Philadelphia pierhead line.

Left side 1,950 ft from Philadelphia pierhead line ( $50 \mathrm{ft}$ from coal pier on New Jersey side).

Trainage area: $7,998 \mathrm{sq} \mathrm{mi}$.

Accomolated volome: 6,380 million $\mathrm{cu} \mathrm{ft}$, below the head of tide at Trenton, N.J.

TeFERENCE MAPS:

Corps of Engineers, Delaware River, Gloucester, N.J., to Cooper Point, file No. 17111.

U.S. Coast and Geodetic Survey, Delaware River, Philadelphia and Camden waterfronts, No. 280.

\section{League Island, Philadelphis, station}

JOCATION: On a line from north side of naval yard pier 4 through channel station +51.3 to covered wharf at Red Bank, N.J. (below ferry slip). (Aug. 1949Dec. 1952, on line from pier 2 through channel station +50.8.)

PAMPLING POINTS:

Right side: $25 \mathrm{ft}$ from naval yard pierhead line.

Right center: $600 \mathrm{ft}$ from naval yard pierhead line.

Center: $1,200 \mathrm{ft}$ from naval yard pierhead line.

Left center: $1,800 \mathrm{ft}$ from naval yard pierhead line.

Left side: $2,200 \mathrm{ft}$ from naval yard pierhead line ( $50 \mathrm{ft}$ from wharf, New Jersey side).

Trainage area: $8,072 \mathrm{sq} \mathrm{mi}$.

ACCUMOLATED volUME: 8,507 million $\mathrm{cu} f \mathrm{ft}$, below the head of tide at Trenton, N.J.

ReFERENCE MaPs:

Corps of Engineers, Delaware River, Schuylkill River to Gloucester, N.J., file No. 17110.

U.S. Coast and Geodetic Survey, Delaware River, Philadelphia and Camden waterfronts, No. 280.

7. Eddystone, Pa., station

docation: In Tinicum navigation range on a line between piers 11 and 12 just above Chester Front light through channel station +97.2 to the middle of Monds Island on New Jersey shore. (Aug. 1949-Dec. 1952, $400 \mathrm{ft}$ upstream from here.)

AMPLING POINTS:

Right side: $20 \mathrm{ft}$ from pierhead line, on Pennsylvania side.

Right center: $800 \mathrm{ft}$ from pierhead line, on Pennsylvania side.

Center: 1,600 ft from pierhead line, on Pennsylvania side.

Left center: 2,500 ft from pierhead line, on Pennsylvania side.

Left side: 3,300 ft from pierhead line, on Pennsylvania side.

Trainage arEa: $10,190 \mathrm{sq}$ mi.

Accumolated voldme: 13,274 million $\mathrm{cu} \mathrm{ft}$, below the head of tide at Trenton, N.J.

REFERENCE MAPS:

Corps of Engineers, Delaware River, Marcus Hook to Eddystone, Pa., file No. 25603.

U.S. Coast and Geodetic Survey, Delaware River, Wilmington to Philadelphia, No. 295 


\section{Marcus Hook, Pa., station}

Location: In Marcus Hook navigation range on a line (below State line) from the water end of the Maritime Exchange reporting station pier through channel station +128.7 to vertical lift bridge over Oldmans Creek.

SAMPLing POINTS:

Right side: $25 \mathrm{ft}$ from pierhead line, on Pennsylvania side.

Right center: $825 \mathrm{ft}$ from pierhead line, on Pennsylvania side.

Center: $1,700 \mathrm{ft}$ from pierhead line, on Pennsylvania side.

Left center: 2,200 ft from pierhead line, on Pennsylvania side.

Left side: 3,100 ft from pierhead line, on Pennsylvania side.

Drainage area: $10,370 \mathrm{sq} \mathrm{mi}$.

Accumolated volome: 17,068 million cu $\mathrm{ft}$. below the head of tide at Trenton, N.J.

REFERENCE MAPS:

Corps of Engineers, Delaware River, Edgemoore, Del., to Marcus Hook, Pa., file No. 25602.

U.S. Coast and Geodetic Survey, Delaware River, Wilmington to Philadelphia. No. 295.

\section{LOCAL VARIATIONS IN WATER-QUALITY PATTERNS}

Because the river water was sampled each month at eight locations, it is possible to show the water-quality changes from month to month and from year to year at each of these sampling locations. Furthermore, the median or average values of the water-quality parameters and the frequency of occurrence of various values of these parameters are also shown. Because cross-section samples were taken at each of the eight sampling locations, variations in the waterquality parameters may also be discussed for each of the cross sections.

At Burlington-Bristol Bridge, Benjamin Franklin Bridge, and Marcus Hook (stations 1, 4, and 8), top and bottom water samples were collected at five points in the river cross section. Top samples were collected 3 feet below the water surface; bottom samples, approximately 3 feet above the riverbed. At the other stations $(2,3$, 5 , 6, and 7, fig. 1), top samples were collected at five points in the cross section, but bottom samples only at the three center points.

In general, the cross sections are uniform in water quality, but river curvature, channel depth, islands, bars, and physical structures do affect the direction of ebb and flood currents. These features may influence the mixing of tributary streams, wastes, or sediment with the water in the main stream, thus causing variations in water quality across the cross section of the river.

At Bristol and at the Benjamin Franklin Bridge, the water on the Pennsylvania side generally has a higher specific conductance (about 5 percent higher) than the water in the rest of the cross section. At Marcus Hook the water on the Pennsylvania side of the river has a higher conductance when the specific conductance is less than 600 (Text continues on page 052 .) 
TABLE 9.-Range and frequency distribution of selected percentile groups of water-quality parameters, Delaware River, 1949-691 [Percent of average cross-section water-quality measurements in which parameter equaled or exceeded value tabulated]

\begin{tabular}{|c|c|c|c|c|c|c|c|c|}
\hline \multirow{4}{*}{$\underset{\text { value }}{\text { Maximum }}$} & \multirow{2}{*}{\multicolumn{7}{|c|}{ Value, in parts per million, equaled or exceeded by indicated percent of samples }} & \multirow{4}{*}{$\underset{\text { value }}{\text { Minimum }}$} \\
\hline & & & & & & & & \\
\hline & & & & & & & & \\
\hline & 5 & 10 & 25 & 50 & 76 & 80 & 95 & \\
\hline
\end{tabular}

1. Delaware River at Bristol-Burlington Bridge, 1949-63

\begin{tabular}{|c|c|c|c|c|c|c|c|c|c|}
\hline $\begin{array}{l}\text { Hydrogen ion concentration } \\
\text { Specific conductance } \\
\text { Chloride micromhos at } 25^{-}{ }_{\text {C. }} \\
\text { Water temperature. } \\
\text { Dissolved oxygen } \\
\text { Do. }\end{array}$ & $\begin{array}{l}7.8 \\
266 \\
17 \\
86 \\
13.3 \\
106\end{array}$ & $\begin{array}{l}7.3 \\
225 \\
13 \\
83 \\
12.0 \\
98\end{array}$ & $\begin{array}{l}7.2 \\
215 \\
11 \\
81 \\
11.8 \\
96\end{array}$ & $\begin{array}{l}7.1 \\
190 \\
8.2 \\
74 \\
11.0 \\
90\end{array}$ & $\begin{array}{l}6.9 \\
145 \\
6.0 \\
56 \\
8.8 \\
84\end{array}$ & $\begin{array}{r}6.8 \\
115 \\
4.5 \\
41 \\
7.0\end{array}$ & $\begin{array}{r}6.7 \\
105 \\
3.6 \\
37 \\
5.5\end{array}$ & $\begin{array}{c}6.5 \\
95 \\
3.1 \\
36 \\
4.6 \\
60\end{array}$ & $\begin{array}{c}6.2 \\
60 \\
2.2 \\
33 \\
2.3 \\
30\end{array}$ \\
\hline
\end{tabular}

2. Delaware River at Torreedale intake, Philadelphia, Pa., 1949-63

\begin{tabular}{|c|c|c|c|c|c|c|c|c|c|}
\hline $\begin{array}{l}\text { Hydrogen ion concentration } \\
\text { Specific conductance. } \\
\text { Chloride micromhos at } \mathbf{2 5}{ }^{\circ} \mathrm{C}_{-} \\
\text {Water temperature. } \\
\text { Dissolved oxygen } \\
\text { Do }\end{array}$ & $\begin{array}{c}8.7 \\
278 \\
26 \\
86 \\
13.4 \\
104\end{array}$ & $\begin{array}{l}7.2 \\
232 \\
15 \\
83 \\
12.2 \\
97\end{array}$ & $\begin{array}{l}7.2 \\
216 \\
13 \\
80 \\
11.6 \\
93\end{array}$ & $\begin{array}{l}7.0 \\
180 \\
8.5 \\
75 \\
10.5 \\
87\end{array}$ & $\begin{array}{c}6.9 \\
150 \\
6.2 \\
56 \\
8.4 \\
79\end{array}$ & $\begin{array}{r}6.7 \\
120 \\
4.9 \\
41 \\
69\end{array}$ & $\begin{array}{r}6.6 \\
105 \\
3.8 \\
37 \\
4.7 \\
55\end{array}$ & $\begin{array}{c}6.5 \\
95 \\
3.0 \\
36 \\
4.0 \\
45\end{array}$ & $\begin{array}{c}6.1 \\
57 \\
2.0 \\
33 \\
2.3 \\
29\end{array}$ \\
\hline
\end{tabular}

3. Dela ware River at Lehigh Avenue, Philadelphin, Pa., 1949-63

\begin{tabular}{|c|c|c|c|c|c|c|c|c|c|}
\hline $\begin{array}{l}\text { Hydrogen ion concentration } \\
\text { Specific conductance } \\
\text { Chloride } \\
\text { Water temperature. micromhos at } 25^{\circ} \mathbf{C}_{--} \\
\text {Dissolved oxygen. } \\
\text { Do }\end{array}$ & $\begin{array}{l}7.6 \\
571 \\
97 \\
85 \\
12.7 \\
101\end{array}$ & $\begin{array}{l}7.1 \\
375 \\
35 \\
83 \\
11.4 \\
89\end{array}$ & $\begin{array}{l}7.0 \\
280 \\
22 \\
81 \\
10.8 \\
85\end{array}$ & $\begin{array}{l}6.9 \\
215 \\
12 \\
75 \\
9.5 \\
78\end{array}$ & $\begin{array}{r}6.7 \\
165 \\
8.0 \\
56 \\
6.5\end{array}$ & $\begin{array}{l}6.6 \\
130 \\
5.3 \\
41 \\
2.5 \\
30\end{array}$ & $\begin{array}{l}6.5 \\
110 \\
4.0 \\
37 \\
1.6\end{array}$ & $\begin{array}{c}6.4 \\
105 \\
3.7 \\
36 \\
1.0 \\
11\end{array}$ & $\begin{array}{c}6.0 \\
57 \\
2.5 \\
33 \\
3^{.2}\end{array}$ \\
\hline
\end{tabular}

See footnote at end of table. 
TABLE 9.-Range and frequency distribution of selected percentile groups of water-quality parameters, Delaware River, 1949-691-Con. [Percent of average cross-section water-quality measurements in which parameter equaled or exceeded value tabulated]

\begin{tabular}{|c|c|c|c|c|c|c|c|c|c|}
\hline & \multirow{2}{*}{$\underset{\text { value }}{\text { Maximum }}$} & \multicolumn{7}{|c|}{ Value, in parts per million, equaled or exceeded by indicated percent of samples } & \multirow{2}{*}{$\underset{\text { value }}{\text { Minimum }}$} \\
\hline & & 5 & 10 & 25 & 50 & 75 & 90 & 95 & \\
\hline \multicolumn{10}{|c|}{ 4. Dela ware River at Benjamin Franklin Bridge, 1949-63 } \\
\hline 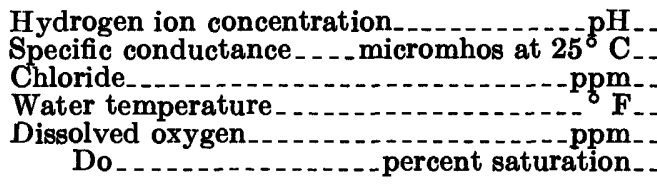 & $\begin{array}{c}7.7 \\
876 \\
172 \\
84 \\
12.5 \\
100\end{array}$ & $\begin{array}{l}7.1 \\
390 \\
48 \\
83 \\
10.7 \\
87\end{array}$ & $\begin{array}{l}7.0 \\
310 \\
27 \\
80 \\
10.0 \\
80\end{array}$ & $\begin{array}{c}6.8 \\
230 \\
14 \\
75 \\
9.2 \\
70\end{array}$ & $\begin{array}{r}6.7 \\
170 \\
8.8 \\
56 \\
5.7 \\
55\end{array}$ & $\begin{array}{c}6.5 \\
130 \\
6.3 \\
42 \\
2.0 \\
22\end{array}$ & $\begin{array}{r}6.4 \\
120 \\
5.0 \\
37 \\
1.0\end{array}$ & $\begin{array}{r}6.3 \\
110 \\
4.5 \\
36 \\
0.8 \\
9.0\end{array}$ & $\begin{array}{c}6.0 \\
61 \\
33 \\
33 \\
0 \\
0\end{array}$ \\
\hline \multicolumn{10}{|c|}{ 5. Dela ware River at Wharton Street, Philadelphla, Pa., 1949-63 } \\
\hline 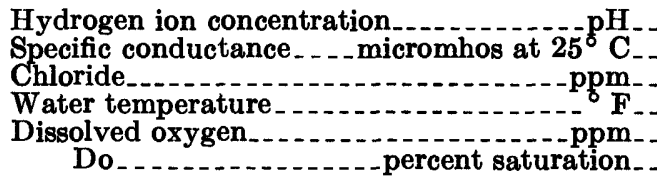 & $\begin{array}{l}7.5 \\
753 \\
137 \\
85 \\
11.6 \\
91\end{array}$ & $\begin{array}{l}7.0 \\
465 \\
62 \\
83 \\
10.5 \\
86\end{array}$ & $\begin{array}{c}6.9 \\
335 \\
28 \\
81 \\
9.9 \\
80\end{array}$ & $\begin{array}{l}6.8 \\
250 \\
15 \\
75 \\
8.5 \\
66\end{array}$ & $\begin{array}{c}6.6 \\
185 \\
9.6 \\
59 \\
4.1 \\
42\end{array}$ & $\begin{array}{c}6.5 \\
140 \\
6.6 \\
43 \\
1.8 \\
20\end{array}$ & $\begin{array}{r}6.4 \\
120 \\
5.1 \\
38 \\
11.0\end{array}$ & $\begin{array}{c}6.3 \\
110 \\
4.4 \\
36 \\
5\end{array}$ & $\begin{array}{c}5.9 \\
68 \\
2.0 \\
34 \\
0\end{array}$ \\
\hline \multicolumn{10}{|c|}{ 6. Dela ware River at League Island, Philadelphia, Pa., 1949-63 } \\
\hline $\begin{array}{l}\text { Hydrogen ion concentration } \\
\text { Specific conductance } \\
\text { Chloride } \\
\text { Water temperature } \\
\text { Dissolved oxygen } \\
\text { Do }\end{array}$ & $\begin{array}{l}7.6 \\
1,180 \\
275 \\
86 \\
12.1 \\
94\end{array}$ & $\begin{array}{l}7.0 \\
680 \\
144 \\
83 \\
10.3 \\
82\end{array}$ & $\begin{array}{c}6.9 \\
470 \\
50 \\
81 \\
9.5 \\
71\end{array}$ & $\begin{array}{l}6.7 \\
270 \\
16 \\
75 \\
7.9 \\
63\end{array}$ & $\begin{array}{l}6.6 \\
210 \\
11 \\
59 \\
3.4 \\
38\end{array}$ & $\begin{array}{c}6.4 \\
160 \\
7.7 \\
43 \\
1.9 \\
23\end{array}$ & $\begin{array}{c}6.3 \\
135 \\
5.8 \\
38 \\
1.2 \\
15\end{array}$ & $\begin{array}{r}6.2 \\
120 \\
4.8 \\
37 \\
10^{.5}\end{array}$ & $\begin{array}{l}5.9 \\
75 \\
1.7 \\
34 \\
0 \\
0\end{array}$ \\
\hline
\end{tabular}


7. Dela ware River at Eddyatone, Pa., 1949-63

\begin{tabular}{|c|c|c|c|c|c|c|c|c|c|}
\hline $\begin{array}{l}\text { Hydrogen ion concentration } \\
\text { Specific conductance } \\
\text { Chloride. } \\
\text { Water temperature } \\
\text { Dissolved oxygen } \\
\text { Do. }\end{array}$ & $\begin{array}{l}7.4 \\
3,620 \\
972 \\
86 \\
11.4 \\
91\end{array}$ & $\begin{array}{c}7.0 \\
1,600 \\
440 \\
83 \\
9.6 \\
77\end{array}$ & $\begin{array}{l}6.9 \\
980 \\
230 \\
81 \\
8.5\end{array}$ & $\begin{array}{l}6.7 \\
310 \\
25 \\
7.5 \\
7.2 \\
58\end{array}$ & $\begin{array}{l}6.6 \\
220 \\
13 \\
58 \\
4.0 \\
40\end{array}$ & $\begin{array}{l}6.4 \\
180 \\
9.0 \\
43 \\
2.3 \\
26\end{array}$ & $\begin{array}{c}6.3 \\
150 \\
6.8 \\
39 \\
1.3\end{array}$ & $\begin{array}{l}6.2 \\
140 \\
5.8 \\
37 \\
1.0 \\
12\end{array}$ & $\begin{array}{r}6.0 \\
78 \\
4.0 \\
34 \\
6\end{array}$ \\
\hline \multicolumn{10}{|c|}{ 8. Dela ware River at Marcus Hook, Pa., 1949-63 } \\
\hline $\begin{array}{l}\text { Hydrogen ion concentration } \\
\text { Specific conductance. } \\
\text { Chloride. } \\
\text { Water temperature } \\
\text { Dissolved oxygen } \\
\text { Do }\end{array}$ & $\begin{array}{l}7.7 \\
6,500 \\
1,940 \\
86 \\
10.7 \\
87\end{array}$ & $\begin{array}{c}6.9 \\
3,100 \\
1,140 \\
83 \\
9.5 \\
76\end{array}$ & $\begin{array}{c}6.8 \\
2,200 \\
620 \\
81 \\
8.5 \\
67\end{array}$ & $\begin{array}{l}\mathbf{6 . 6} \\
550 \\
90 \\
75 \\
7.0 \\
57\end{array}$ & $\begin{array}{l}6.5 \\
250 \\
15 \\
57 \\
4.5\end{array}$ & $\begin{array}{c}6.3 \\
190 \\
9.8 \\
44 \\
2.5 \\
30\end{array}$ & $\begin{array}{c}5.9 \\
160 \\
7.4 \\
39 \\
1.7 \\
20\end{array}$ & $\begin{array}{c}5.7 \\
145 \\
6.4 \\
38 \\
1.4 \\
15\end{array}$ & $\begin{array}{c}5.0 \\
89 \\
4.7 \\
34 \\
1.0 \\
11\end{array}$ \\
\hline
\end{tabular}

1 Averages of 5-point cross-section samples collected monthly August 1949-July 1963. 
TABLE 10.-Annual maximum, mean, and minimum of water-quality parameters, Delaware River, 1950-631

\begin{tabular}{|c|c|c|c|c|c|c|c|c|c|c|c|c|c|c|c|c|c|c|c|c|c|}
\hline \multirow{3}{*}{ Year } & \multirow{2}{*}{\multicolumn{3}{|c|}{$\begin{array}{l}\text { Hydrogen ion } \\
\text { (pH) }\end{array}$}} & \multirow{2}{*}{\multicolumn{3}{|c|}{$\begin{array}{l}\text { Speciffic conductance } \\
\left.\text { (micromhos at } 25^{\circ} \mathrm{C}\right)\end{array}$}} & \multirow{2}{*}{\multicolumn{3}{|c|}{ Chloride (ppm) }} & \multirow{2}{*}{\multicolumn{3}{|c|}{$\underset{(\mathrm{ppm})}{\text { Suspended sediment }}$}} & \multirow{2}{*}{\multicolumn{3}{|c|}{$\begin{array}{l}\text { Water temperature } \\
{ }_{\left({ }^{\circ} F\right)}\end{array}$}} & \multicolumn{6}{|c|}{ Dissolved oxygen } \\
\hline & & & & & & & & & & & & & & & & \multicolumn{3}{|c|}{ Parts per million } & \multicolumn{3}{|c|}{ Percent saturation } \\
\hline & Max & Median & Min & $\operatorname{Max}$ & Mean & Min & $\operatorname{Max}$ & Megn & Mm & Max & Mean & Min & Max & Mean & Min & Max & Mean & Min & $\operatorname{Max}$ & Mean & Min \\
\hline
\end{tabular}

1. Dela ware River at Bristol-Burlington Bridge, 1950-63

\begin{tabular}{|c|c|c|c|c|c|c|c|c|c|c|c|c|c|c|c|c|c|c|c|c|c|}
\hline $\begin{array}{l}1950 \\
1951 \\
1952 \\
1954 \\
1955 \\
1956 \\
1957 \\
1958 \\
1959 \\
1961 \\
1962\end{array}$ & $\begin{array}{l}7.1 \\
7.2 \\
7.2 \\
7.0 \\
7.2 \\
7.1 \\
7.3 \\
7.2 \\
7.3 \\
7.4 \\
7.3 \\
7.1 \\
7.2 \\
7.3\end{array}$ & $\begin{array}{l}6.8 \\
6.9 \\
6.7 \\
6.8 \\
6.9 \\
6.7 \\
6.9 \\
7.0 \\
7.0 \\
6.9 \\
7.0 \\
6.8 \\
7.1 \\
7.1\end{array}$ & $\begin{array}{l}6.5 \\
6.5 \\
6.4 \\
6.6 \\
6.7 \\
6.2 \\
6.7 \\
6.7 \\
6.4 \\
6.6 \\
6.8 \\
6.7 \\
6.9 \\
6.8\end{array}$ & $\begin{array}{l}213 \\
216 \\
235 \\
256 \\
252 \\
245 \\
197 \\
236 \\
193 \\
200 \\
167 \\
222 \\
223 \\
266\end{array}$ & $\begin{array}{l}135 \\
138 \\
147 \\
163 \\
165 \\
145 \\
155 \\
178 \\
141 \\
152 \\
139 \\
143 \\
164 \\
186\end{array}$ & $\begin{array}{r}76 \\
60 \\
86 \\
80 \\
90 \\
97 \\
84 \\
95 \\
119 \\
104 \\
104 \\
91 \\
81 \\
95 \\
80 \\
80\end{array}$ & $\begin{array}{c}11 \\
11 \\
10 \\
16 \\
17 \\
16 \\
7.9 \\
13 \\
8.1 \\
10 \\
8.4 \\
12 \\
11 \\
14\end{array}$ & $\begin{array}{l}5.9 \\
5.3 \\
5.1 \\
8.0 \\
9.0 \\
6.7 \\
5.5 \\
8.4 \\
5.1 \\
6.6 \\
5.3 \\
7.0 \\
7.9 \\
8.6\end{array}$ & $\begin{array}{l}3.3 \\
2.7 \\
2.2 \\
3.6 \\
4.0 \\
2.7 \\
2.9 \\
4.4 \\
3.2 \\
4.0 \\
2.6 \\
3.1 \\
4.0 \\
2.3\end{array}$ & $\begin{array}{r}40 \\
142 \\
73 \\
38 \\
32 \\
63 \\
26 \\
61 \\
54 \\
39 \\
332 \\
208 \\
238 \\
167\end{array}$ & $\begin{array}{r}18 \\
36 \\
24 \\
15 \\
17 \\
23 \\
16 \\
28 \\
27 \\
24 \\
178 \\
62 \\
75 \\
81\end{array}$ & $\begin{array}{r}8 \\
7 \\
9 \\
7 \\
7 \\
9 \\
10 \\
13 \\
11 \\
14 \\
18 \\
21 \\
21 \\
30\end{array}$ & $\begin{array}{l}79 \\
76 \\
81 \\
86 \\
80 \\
85 \\
80 \\
85 \\
82 \\
84 \\
76 \\
84 \\
81 \\
83\end{array}$ & $\begin{array}{l}57 \\
57 \\
57 \\
58 \\
56 \\
58 \\
56 \\
57 \\
55 \\
59 \\
60 \\
58 \\
57 \\
59\end{array}$ & $\begin{array}{l}\mathbf{3 4} \\
\mathbf{3 4} \\
38 \\
36 \\
\mathbf{3 6} \\
\mathbf{3 4} \\
\mathbf{3 5} \\
\mathbf{3 6} \\
\mathbf{3 3} \\
\mathbf{3 5} \\
\mathbf{3 8} \\
\mathbf{3 4} \\
\mathbf{3 4} \\
\mathbf{3 5}\end{array}$ & $\begin{array}{l}13.3 \\
12.9 \\
12.2 \\
11.7 \\
11.8 \\
11.5 \\
11.7 \\
11.5 \\
11.7 \\
11.8 \\
11.9 \\
11.9 \\
12.6 \\
12.9\end{array}$ & $\begin{array}{l}9.1 \\
9.6 \\
9.1 \\
8.4 \\
8.7 \\
9.2 \\
9.0 \\
8.1 \\
8.8 \\
9.0 \\
8.0 \\
7.9 \\
8.4 \\
7.4\end{array}$ & $\begin{array}{l}4.0 \\
6.4 \\
4.5 \\
3.5 \\
2.8 \\
4.5 \\
6.3 \\
5.0 \\
5.9 \\
5.5 \\
5.0 \\
4.4 \\
3.2 \\
2.3\end{array}$ & $\begin{array}{r}98 \\
104 \\
97 \\
94 \\
89 \\
93 \\
88 \\
84 \\
97 \\
92 \\
98 \\
90 \\
95 \\
95\end{array}$ & $\begin{array}{l}80 \\
81 \\
81 \\
67 \\
78 \\
83 \\
77 \\
67 \\
76 \\
76 \\
70 \\
72 \\
79 \\
68\end{array}$ & $\begin{array}{l}59 \\
54 \\
58 \\
38 \\
67 \\
59 \\
54 \\
45 \\
62 \\
59 \\
59 \\
50 \\
38 \\
30\end{array}$ \\
\hline
\end{tabular}

2. Dela ware River at Torresdale intake, Philladelphia, Pa., 1950-63

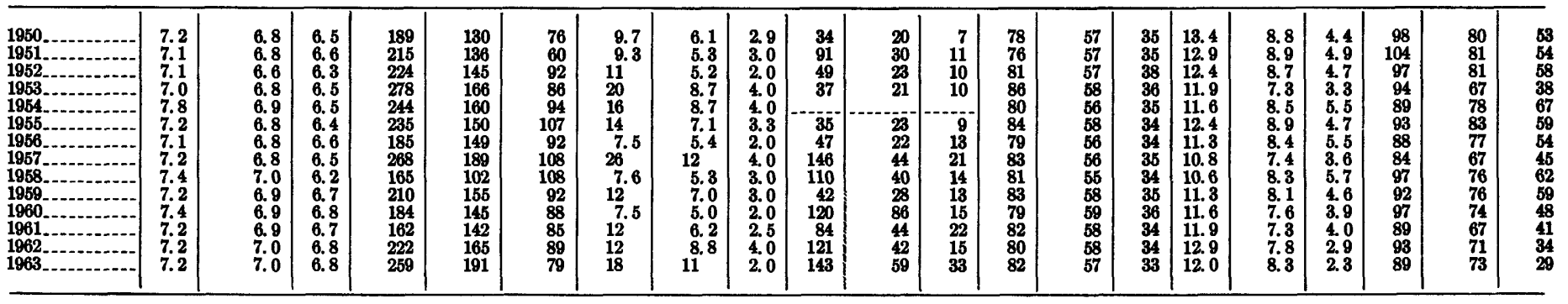




\begin{tabular}{|c|c|c|c|c|c|c|c|c|c|c|c|c|c|c|c|c|c|c|c|c|c|}
\hline $\begin{array}{l}1950 \\
1951 \\
1952 \\
1953 \\
1954 \\
19556 \\
19567 \\
1958 \\
1959- \\
1960 \\
1961\end{array}$ & $\begin{array}{l}7.0 \\
6.9 \\
7.0 \\
7.0 \\
6.9 \\
7.0 \\
7.1 \\
7.4 \\
7.2 \\
7.1 \\
7.1 \\
7.2 \\
7.1 \\
7.2\end{array}$ & $\begin{array}{l}6.6 \\
6.7 \\
6.7 \\
6.6 \\
6.6 \\
6.6 \\
6.8 \\
6.7 \\
6.9 \\
6.7 \\
6.8 \\
6.9 \\
6.9 \\
6.9\end{array}$ & $\begin{array}{l}6.3 \\
6.3 \\
6.5 \\
6.4 \\
6.4 \\
6.2 \\
6.4 \\
6.3 \\
6.2 \\
6.3 \\
6.6 \\
6.6 \\
6.7 \\
6.5\end{array}$ & $\begin{array}{l}270 \\
247 \\
290 \\
429 \\
404 \\
307 \\
239 \\
571 \\
195 \\
241 \\
208 \\
298 \\
277 \\
408\end{array}$ & $\begin{array}{l}159 \\
153 \\
165 \\
214 \\
198 \\
174 \\
178 \\
286 \\
145 \\
173 \\
155 \\
172 \\
192 \\
244\end{array}$ & $\begin{array}{r}84 \\
58 \\
104 \\
106 \\
102 \\
127 \\
100 \\
127 \\
114 \\
88 \\
88 \\
84 \\
109 \\
89\end{array}$ & $\begin{array}{l}14 \\
11 \\
18 \\
43 \\
40 \\
25 \\
14 \\
97 \\
11 \\
12 \\
12 \\
21 \\
19 \\
48\end{array}$ & $\begin{array}{c}7.7 \\
6.7 \\
7.3 \\
14 \\
14 \\
9.4 \\
8.3 \\
31.3 \\
6.5 \\
8.6 \\
6.8 \\
9.0 \\
10.9 \\
19\end{array}$ & $\begin{array}{l}3.7 \\
3.0 \\
3.3 \\
4.0 \\
4.0 \\
4.0 \\
3.3 \\
4.3 \\
3.8 \\
2.5 \\
3.0 \\
2.5 \\
4.0 \\
3.0\end{array}$ & \begin{tabular}{r}
61 \\
101 \\
48 \\
35 \\
\hdashline 41 \\
30 \\
139 \\
245 \\
67 \\
120 \\
84 \\
121 \\
108
\end{tabular} & $\begin{array}{l}24 \\
32 \\
20 \\
25 \\
-25 \\
21 \\
38 \\
53 \\
31 \\
86 \\
44 \\
42 \\
45\end{array}$ & \begin{tabular}{r|}
10 \\
13 \\
7 \\
13 \\
12 \\
13 \\
15 \\
19 \\
13 \\
15 \\
22 \\
15 \\
24
\end{tabular} & $\begin{array}{l}79 \\
78 \\
83 \\
85 \\
80 \\
83 \\
80 \\
84 \\
82 \\
83 \\
80 \\
83 \\
81 \\
81\end{array}$ & $\begin{array}{l}57 \\
57 \\
58 \\
59 \\
57 \\
58 \\
56 \\
57 \\
55 \\
59 \\
58 \\
58 \\
58 \\
58\end{array}$ & $\begin{array}{l}\mathbf{3 5} \\
\mathbf{3 6} \\
\mathbf{3 8} \\
\mathbf{3 6} \\
\mathbf{3 4} \\
\mathbf{3 3} \\
\mathbf{3 4} \\
\mathbf{3 5} \\
\mathbf{3 5} \\
\mathbf{3 5} \\
38 \\
34 \\
36 \\
\mathbf{3 4}\end{array}$ & \begin{tabular}{|l|}
12.7 \\
12.3 \\
12.4 \\
11.6 \\
11.5 \\
10.9 \\
10.2 \\
10.7 \\
10.4 \\
9.6 \\
12.0 \\
11.8 \\
11.4 \\
10.9
\end{tabular} & $\begin{array}{l}5.9 \\
7.0 \\
6.8 \\
5.4 \\
6.1 \\
7.2 \\
6.4 \\
5.2 \\
6.8 \\
6.0 \\
6.4 \\
5.8 \\
6.4 \\
5.8\end{array}$ & $\begin{array}{r}0.7 \\
.9 \\
.9 \\
1.5 \\
1.3 \\
2.0 \\
1.3 \\
2.4 \\
1.6 \\
2.8 \\
1.7 \\
1.7 \\
1.3\end{array}$ & $\begin{array}{r}101 \\
100 \\
94 \\
85 \\
82 \\
85 \\
81 \\
76 \\
86 \\
80 \\
90 \\
89 \\
88 \\
78\end{array}$ & $\begin{array}{l}50 \\
60 \\
61 \\
46 \\
53 \\
61 \\
57 \\
45 \\
60 \\
55 \\
58 \\
50 \\
56 \\
50\end{array}$ & $\begin{array}{l}8 \\
11 \\
12 \\
7 \\
15 \\
23 \\
25 \\
16 \\
30 \\
19 \\
19 \\
18 \\
21 \\
16\end{array}$ \\
\hline \multicolumn{22}{|c|}{ 4. Dela ware River at Benjamin Franklin Bridge, Philadelphia, Pa., 1950-63 } \\
\hline $\begin{array}{l}1950 \\
1951 \\
1952 \\
1953 \\
1954 \\
1955- \\
1956 \\
1957 \\
19589 \\
1960 \\
1961 \\
1962 \\
1963\end{array}$ & $\begin{array}{l}6.7 \\
6.9 \\
6.8 \\
6.9 \\
6.8 \\
6.9 \\
7.0 \\
7.7 \\
7.1 \\
7.0 \\
7.0 \\
7.0 \\
7.1 \\
7.2\end{array}$ & $\begin{array}{l}6.5 \\
6.6 \\
6.6 \\
6.6 \\
6.6 \\
6.5 \\
6.7 \\
6.7 \\
6.9 \\
6.7 \\
6.8 \\
6.8 \\
6.8 \\
6.8\end{array}$ & $\begin{array}{l}6.0 \\
6.3 \\
6.3 \\
6.4 \\
6.3 \\
6.2 \\
6.5 \\
6.3 \\
6.1 \\
6.3 \\
6.4 \\
6.6 \\
6.5 \\
6.5\end{array}$ & $\begin{array}{l}309 \\
261 \\
218 \\
453 \\
642 \\
334 \\
252 \\
821 \\
204 \\
255 \\
215 \\
306 \\
287 \\
520\end{array}$ & $\begin{array}{l}175 \\
163 \\
171 \\
225 \\
238 \\
183 \\
183 \\
337 \\
151 \\
182 \\
161 \\
177 \\
202 \\
270\end{array}$ & $\begin{array}{r}85 \\
61 \\
101 \\
116 \\
113 \\
130 \\
105 \\
130 \\
115 \\
92 \\
91 \\
85 \\
112 \\
97\end{array}$ & $\begin{array}{r}23 \\
15 \\
22 \\
50 \\
110 \\
29 \\
15 \\
172 \\
12 \\
16 \\
10 \\
24 \\
18 \\
67\end{array}$ & $\begin{array}{c}10 \\
8.4 \\
7.1 \\
16 \\
23 \\
11 \\
9.2 \\
44 \\
7.1 \\
10 \\
7.9 \\
9.6 \\
12 \\
22\end{array}$ & $\begin{array}{l}4.4 \\
3.3 \\
3.9 \\
6.0 \\
4.6 \\
5.1 \\
4.7 \\
6.1 \\
4.1 \\
4.5 \\
4.8 \\
3.5 \\
4.0 \\
4.7\end{array}$ & $\begin{array}{r}68 \\
97 \\
36 \\
45 \\
49 \\
64 \\
99 \\
79 \\
269 \\
60 \\
122 \\
84 \\
78 \\
82\end{array}$ & $\begin{array}{l}34 \\
36 \\
25 \\
33 \\
31 \\
32 \\
34 \\
43 \\
60 \\
34 \\
79 \\
46 \\
49 \\
44\end{array}$ & $\begin{array}{l}14 \\
15 \\
9 \\
13 \\
13 \\
18 \\
14 \\
25 \\
22 \\
16 \\
20 \\
20 \\
4 \\
25\end{array}$ & $\begin{array}{l}79 \\
79 \\
82 \\
83 \\
81 \\
83 \\
79 \\
83 \\
82 \\
83 \\
80 \\
83 \\
79 \\
81\end{array}$ & $\begin{array}{l}57 \\
57 \\
58 \\
59 \\
57 \\
58 \\
57 \\
57 \\
55 \\
59 \\
58 \\
59 \\
58 \\
58\end{array}$ & $\begin{array}{l}36 \\
36 \\
38 \\
36 \\
34 \\
33 \\
35 \\
35 \\
35 \\
35 \\
38 \\
34 \\
36 \\
34\end{array}$ & $\begin{array}{r}10.3 \\
12.4 \\
12.5 \\
9.9 \\
11.0 \\
10.5 \\
9.9 \\
9.6 \\
10.4 \\
9.6 \\
11.6 \\
12.0 \\
11.0 \\
10.3\end{array}$ & $\begin{array}{l}4.9 \\
6.1 \\
6.2 \\
4.8 \\
5.3 \\
6.6 \\
6.0 \\
4.8 \\
6.2 \\
5.0 \\
6.3 \\
5.6 \\
5.9 \\
5.3\end{array}$ & $\begin{array}{l}0.0 \\
.6 \\
1.0 \\
.6 \\
1.1 \\
1.5 \\
1.9 \\
1.1 \\
.9 \\
1.7 \\
2.4 \\
1.3 \\
1.5 \\
1.1\end{array}$ & $\begin{array}{r}87 \\
100 \\
95 \\
76 \\
79 \\
90 \\
78 \\
69 \\
90 \\
81 \\
88 \\
88 \\
86 \\
86\end{array}$ & $\begin{array}{l}41 \\
53 \\
55 \\
42 \\
45 \\
58 \\
53 \\
41 \\
54 \\
46 \\
57 \\
48 \\
52 \\
46\end{array}$ & $\begin{array}{r}0 \\
7 \\
12 \\
7 \\
12 \\
19 \\
22 \\
13 \\
9 \\
22 \\
26 \\
16 \\
18 \\
14\end{array}$ \\
\hline \multicolumn{22}{|c|}{ 5. Dela ware River at Wharton Street, Philadelphia, Pa., 1950-63 } \\
\hline $\begin{array}{l}1950 \\
1951 \\
1952 \\
1953 \\
1954 \\
1955 \\
1956 \\
1958 \\
1959 \\
1960\end{array}$ & $\begin{array}{l}6.7 \\
6.8 \\
6.8 \\
6.8 \\
6.8 \\
6.7 \\
7.0 \\
7.5 \\
7.1 \\
6.9 \\
7.0 \\
7.0 \\
7.0 \\
7.1\end{array}$ & $\begin{array}{l}6.5 \\
6.6 \\
6.6 \\
6.6 \\
6.6 \\
6.5 \\
6.7 \\
6.7 \\
6.9 \\
6.7 \\
6.7 \\
6.7 \\
6.8 \\
6.8\end{array}$ & $\begin{array}{l}6.2 \\
6.4 \\
6.0 \\
6.4 \\
6.2 \\
6.1 \\
6.3 \\
6.3 \\
6.1 \\
6.4 \\
6.4 \\
6.2 \\
6.4 \\
6.5\end{array}$ & $\begin{array}{l}305 \\
327 \\
325 \\
500 \\
666 \\
432 \\
250 \\
646 \\
209 \\
270 \\
229 \\
352 \\
300 \\
748\end{array}$ & $\begin{array}{l}175 \\
163 \\
171 \\
225 \\
238 \\
183 \\
183 \\
337 \\
151 \\
182 \\
167 \\
198 \\
218 \\
296\end{array}$ & $\begin{array}{r}81 \\
70 \\
98 \\
109 \\
111 \\
143 \\
104 \\
140 \\
118 \\
95 \\
73 \\
93 \\
104 \\
86\end{array}$ & $\begin{array}{r}21 \\
24 \\
22 \\
73 \\
123 \\
57 \\
16 \\
116 \\
12 \\
18 \\
14 \\
32 \\
21 \\
137\end{array}$ & $\begin{array}{c}10 \\
8.4 \\
7.1 \\
16 \\
23 \\
11 \\
9.2 \\
44 \\
7.8 \\
9.7 \\
8.2 \\
12 \\
14 \\
39\end{array}$ & $\begin{array}{l}4.7 \\
3.0 \\
3.0 \\
4.0 \\
4.0 \\
7.0 \\
5.0 \\
5.3 \\
4.0 \\
3.5 \\
2.0 \\
3.5 \\
5.0 \\
3.0\end{array}$ & $\begin{array}{r}49 \\
43 \\
61 \\
134 \\
67 \\
124 \\
104 \\
93 \\
61\end{array}$ & $\begin{array}{l}32 \\
34 \\
43 \\
60 \\
34 \\
56 \\
47 \\
41 \\
39\end{array}$ & $\begin{array}{l}11 \\
14 \\
18 \\
19 \\
11 \\
19 \\
12 \\
11 \\
23\end{array}$ & $\begin{array}{l}80 \\
81 \\
82 \\
84 \\
80 \\
85 \\
80 \\
84 \\
82 \\
84 \\
81 \\
82 \\
79 \\
81\end{array}$ & $\begin{array}{l}57 \\
57 \\
58 \\
59 \\
57 \\
58 \\
57 \\
57 \\
55 \\
59 \\
61 \\
59 \\
58 \\
59\end{array}$ & $\begin{array}{l}\mathbf{3 7} \\
\mathbf{3 6} \\
\mathbf{3 8} \\
\mathbf{3 7} \\
\mathbf{3 4} \\
\mathbf{3 4} \\
\mathbf{3 5} \\
\mathbf{3 5} \\
\mathbf{3 5} \\
\mathbf{3 6} \\
\mathbf{3 9} \\
\mathbf{3 4} \\
\mathbf{3 6} \\
\mathbf{3 4}\end{array}$ & $\begin{array}{r}11.5 \\
10.8 \\
11.6 \\
10.4 \\
11.1 \\
9.7 \\
9.0 \\
9.5 \\
10.5 \\
9.1 \\
10.9 \\
11.4 \\
10.3 \\
10.4\end{array}$ & $\begin{array}{l}4.9 \\
6.1 \\
6.2 \\
4.8 \\
5.3 \\
6.6 \\
6.0 \\
4.8 \\
6.2 \\
5.0 \\
4.7 \\
4.9 \\
4.8 \\
4.2\end{array}$ & $\begin{array}{r}0.0 \\
.3 \\
.1 \\
.8 \\
1.1 \\
1.2 \\
2.3 \\
1.0 \\
1.4 \\
1.8 \\
1.6 \\
1.1 \\
1.0 \\
.8\end{array}$ & $\begin{array}{l}91 \\
89 \\
91 \\
85 \\
83 \\
77 \\
71 \\
79 \\
78 \\
69 \\
83 \\
86 \\
90 \\
86\end{array}$ & $\begin{array}{l}40 \\
48 \\
49 \\
41 \\
41 \\
47 \\
49 \\
38 \\
49 \\
45 \\
43 \\
42 \\
41 \\
37\end{array}$ & $\begin{array}{r}0 \\
4 \\
1 \\
9 \\
13 \\
13 \\
27 \\
12 \\
18 \\
20 \\
20 \\
13 \\
12 \\
8\end{array}$ \\
\hline
\end{tabular}


TABLE 10.-Annual maximum, mean, and minimum of water-quality parameters, Delaware River, 1950-631-Continued

\begin{tabular}{|c|c|c|c|c|c|c|c|c|c|c|c|c|c|c|c|c|c|c|c|c|c|}
\hline \multirow{3}{*}{ Year } & \multirow{2}{*}{\multicolumn{3}{|c|}{$\underset{(\mathrm{pH})}{\text { Hydrogen ion }}$}} & \multirow{2}{*}{\multicolumn{3}{|c|}{$\begin{array}{l}\text { Specific conductance } \\
\left.\text { l(micromhos at } 25^{\circ} \mathrm{C}\right)\end{array}$}} & \multirow{2}{*}{\multicolumn{3}{|c|}{ Chloride (ppm) }} & \multirow{2}{*}{\multicolumn{3}{|c|}{$\begin{array}{c}\text { Suspended sediment } \\
(\mathrm{ppm})\end{array}$}} & \multirow{2}{*}{\multicolumn{3}{|c|}{ Water temperature }} & \multicolumn{6}{|c|}{ Dissolved oxygen } \\
\hline & & & & & & & & & & & & & & & & \multicolumn{3}{|c|}{ Parts per million } & \multicolumn{3}{|c|}{ Percent saturation } \\
\hline & Max & Median & Min & Max & Mean & Min & $\operatorname{Max}$ & Mean & Min & Max & Mean & Min & Max & Mean & Min & Max & Mean & Min & Max & Mean & Min \\
\hline
\end{tabular}

6. Dela ware River at League Island, Philadelphia, Pa., 1950-63

\begin{tabular}{|c|c|c|c|c|c|c|c|c|c|c|c|c|c|c|c|c|c|c|c|c|}
\hline $\begin{array}{l}1950 \\
1951 \\
1952 \\
1953 \\
1954 \\
1956 \\
1957 \\
1958 \\
1959 \\
1960 \\
1961 \\
1962\end{array}$ & $\begin{array}{l}6.6 \\
7.6 \\
6.8 \\
6.8 \\
6.8 \\
6.7 \\
7.0 \\
7.5 \\
7.1 \\
6.9 \\
6.9 \\
6.9 \\
6.9 \\
6.9\end{array}$ & $\begin{array}{l}6.4 \\
6.6 \\
6.5 \\
6.5 \\
6.4 \\
6.4 \\
6.7 \\
6.6 \\
6.8 \\
6.7 \\
6.6 \\
6.6 \\
6.7 \\
6.6\end{array}$ & $\begin{array}{l}\text { 6.2 } \\
6.3 \\
6.2 \\
6.3 \\
6.2 \\
6.0 \\
6.2 \\
6.3 \\
5.9 \\
6.4 \\
6.5 \\
6.1 \\
6.5 \\
6.4\end{array}$ & $\begin{array}{r}351 \\
374 \\
362 \\
700 \\
945 \\
639 \\
281 \\
1,180 \\
243 \\
303 \\
250 \\
\mathbf{4 3 8} \\
\mathbf{3 7 3} \\
1,070\end{array}$ & $\begin{array}{l}193 \\
197 \\
196 \\
273 \\
354 \\
241 \\
210 \\
502 \\
177 \\
216 \\
185 \\
216 \\
249 \\
392\end{array}$ & \begin{tabular}{r|}
90 \\
84 \\
107 \\
114 \\
129 \\
161 \\
111 \\
161 \\
132 \\
114 \\
82 \\
101 \\
107 \\
97
\end{tabular} & $\begin{array}{r}26 \\
35 \\
28 \\
128 \\
193 \\
131 \\
18 \\
275 \\
15 \\
22 \\
14 \\
56 \\
29 \\
206\end{array}$ & $\begin{array}{l}11 \\
11 \\
10 \\
27 \\
49 \\
21 \\
11 \\
86 \\
9.1 \\
12.0 \\
9.5 \\
15 \\
15 \\
47\end{array}$ & $\begin{array}{l}4.0 \\
4.0 \\
4.0 \\
4.3 \\
6.0 \\
7.0 \\
6.0 \\
8.0 \\
4.5 \\
5.0 \\
3.0 \\
3.5 \\
1.7 \\
3.5\end{array}$ & \begin{tabular}{r}
55 \\
$\mathbf{9 0}$ \\
82 \\
52 \\
\hdashline 58 \\
$\mathbf{4 4}$ \\
102 \\
177 \\
51 \\
72 \\
100 \\
95 \\
68
\end{tabular} & $\begin{array}{l}31 \\
20 \\
27 \\
28 \\
29 \\
25 \\
\mathbf{3 6} \\
51 \\
30 \\
41 \\
42 \\
39 \\
42\end{array}$ & $\begin{array}{r}10 \\
14 \\
16 \\
18 \\
13 \\
9 \\
13 \\
14 \\
16\end{array}$ & $\begin{array}{l}80 \\
80 \\
83 \\
83 \\
80 \\
85 \\
80 \\
84 \\
82 \\
84 \\
80 \\
83 \\
79 \\
81\end{array}$ & $\begin{array}{l}59 \\
58 \\
58 \\
59 \\
58 \\
59 \\
57 \\
58 \\
56 \\
60 \\
61 \\
61 \\
58 \\
58\end{array}$ & $\begin{array}{l}\mathbf{3 8} \\
\mathbf{3 5} \\
\mathbf{3 7} \\
\mathbf{3 7} \\
\mathbf{3 4} \\
\mathbf{3 4} \\
\mathbf{3 6} \\
\mathbf{3 7} \\
\mathbf{3 6} \\
\mathbf{3 6} \\
\mathbf{3 9} \\
\mathbf{3 4} \\
\mathbf{3 6} \\
\mathbf{3 5}\end{array}$ & $\begin{array}{r}11.9 \\
10.8 \\
12.1 \\
9.4 \\
10.3 \\
9.3 \\
7.8 \\
8.8 \\
10.0 \\
9.2 \\
11.0 \\
10.4 \\
10.3 \\
10.4\end{array}$ & $\begin{array}{l}4.4 \\
5.1 \\
5.4 \\
4.4 \\
4.9 \\
5.1 \\
4.7 \\
4.0 \\
5.9 \\
5.0 \\
4.6 \\
4.7 \\
4.4 \\
3.5\end{array}$ & $\begin{array}{r}0.0 \\
.3 \\
.1 \\
1.0 \\
1.2 \\
1.2 \\
2.3 \\
1.4 \\
2.0 \\
1.8 \\
1.8 \\
1.2 \\
.8 \\
.6\end{array}$ & $\begin{array}{l}94 \\
84 \\
93 \\
73 \\
82 \\
73 \\
65 \\
66 \\
72 \\
79 \\
89 \\
84 \\
83 \\
86\end{array}$ & $\begin{array}{l}37 \\
39 \\
48 \\
39 \\
42 \\
46 \\
42 \\
36 \\
50 \\
46 \\
42 \\
42 \\
38 \\
31\end{array}$ \\
\hline
\end{tabular}

7. Dela ware River at Eddystone, Pa., 1950-63

\begin{tabular}{|c|c|c|c|c|c|c|c|c|c|c|c|c|c|c|c|c|c|c|c|c|c|}
\hline $\begin{array}{l}1950 \\
1951 \\
1952 \\
1953 \\
1954 \\
1956 \\
1957 \\
1958 \\
1959 \\
1960 \\
1961\end{array}$ & $\begin{array}{l}6.6 \\
6.8 \\
6.8 \\
7.0 \\
6.7 \\
6.6 \\
7.0 \\
7.4 \\
7.1 \\
6.9 \\
6.9 \\
7.0 \\
6.9 \\
7.0\end{array}$ & $\begin{array}{l}6.4 \\
6.5 \\
6.5 \\
6.5 \\
6.4 \\
6.4 \\
6.6 \\
6.5 \\
6.8 \\
6.6 \\
6.6 \\
6.6 \\
6.7 \\
6.5\end{array}$ & $\begin{array}{l}6.0 \\
6.3 \\
6.2 \\
6.3 \\
6.0 \\
6.0 \\
6.1 \\
6.0 \\
6.1 \\
6.3 \\
6.4 \\
6.3 \\
6.4 \\
6.0\end{array}$ & $\begin{array}{r}556 \\
933 \\
935 \\
1,590 \\
1,860 \\
1,820 \\
320 \\
3,420 \\
290 \\
510 \\
269 \\
1,060 \\
595 \\
2,020\end{array}$ & $\begin{array}{r}234 \\
261 \\
254 \\
472 \\
619 \\
362 \\
239 \\
1,210 \\
200 \\
268 \\
210 \\
303 \\
315 \\
765\end{array}$ & $\begin{array}{r}102 \\
83 \\
132 \\
142 \\
150 \\
165 \\
137 \\
192 \\
144 \\
131 \\
122 \\
118 \\
134 \\
107\end{array}$ & $\begin{array}{r}62 \\
262 \\
220 \\
433 \\
467 \\
518 \\
22 \\
972 \\
18 \\
18 \\
60 \\
17 \\
245 \\
86 \\
496\end{array}$ & \begin{tabular}{|r|r|}
17 \\
31 \\
27 \\
87 \\
126 \\
126 \\
58 \\
14 \\
312 \\
11 \\
12 \\
21 \\
11 \\
41 \\
28 \\
154
\end{tabular} & $\begin{array}{l}4.7 \\
4.0 \\
4.0 \\
6.0 \\
7.0 \\
7.0 \\
7.0 \\
8.0 \\
6.0 \\
5.5 \\
4.0 \\
4.5 \\
7.0 \\
5.0\end{array}$ & $\begin{array}{r}119 \\
78 \\
203 \\
161 \\
64 \\
93 \\
104 \\
111 \\
205\end{array}$ & \begin{tabular}{r}
56 \\
43 \\
33 \\
35 \\
\hdashline 51 \\
40 \\
69 \\
63 \\
46 \\
45 \\
55 \\
52 \\
69
\end{tabular} & $\begin{array}{l}17 \\
12 \\
32 \\
19 \\
17 \\
18 \\
12 \\
12 \\
16\end{array}$ & $\begin{array}{l}80 \\
81 \\
82 \\
83 \\
80 \\
86 \\
80 \\
83 \\
82 \\
85 \\
81 \\
83 \\
79 \\
82\end{array}$ & $\begin{array}{l}\mathbf{5 9} \\
58 \\
\mathbf{5 8} \\
\mathbf{5 9} \\
58 \\
59 \\
58 \\
58 \\
\mathbf{5 7} \\
\mathbf{6 0} \\
\mathbf{6 2} \\
\mathbf{6 2} \\
\mathbf{5 9} \\
\mathbf{5 8}\end{array}$ & $\begin{array}{l}\mathbf{3 7} \\
\mathbf{3 6} \\
\mathbf{3 8} \\
\mathbf{3 8} \\
\mathbf{3 4} \\
\mathbf{3 4} \\
\mathbf{3 5} \\
\mathbf{3 7} \\
\mathbf{3 7} \\
\mathbf{3 6} \\
\mathbf{4 0} \\
\mathbf{3 6} \\
\mathbf{3 7} \\
\mathbf{3 5}\end{array}$ & $\begin{array}{r}10.6 \\
10.7 \\
11.4 \\
8.1 \\
9.2 \\
8.2 \\
7.3 \\
7.9 \\
9.1 \\
8.9 \\
9.9 \\
11.2 \\
8.4 \\
9.0\end{array}$ & $\begin{array}{l}4.5 \\
4.8 \\
5.4 \\
4.0 \\
4.6 \\
4.6 \\
4.5 \\
3.8 \\
5.7 \\
4.9 \\
4.7 \\
5.3 \\
4.5 \\
3.4\end{array}$ & $\begin{array}{r}0.7 \\
.5 \\
.5 \\
1.4 \\
1.3 \\
1.4 \\
2.5 \\
1.4 \\
2.0 \\
2.2 \\
1.8 \\
2.1 \\
1.4 \\
.6\end{array}$ & $\begin{array}{l}85 \\
86 \\
86 \\
63 \\
74 \\
70 \\
59 \\
58 \\
68 \\
69 \\
88 \\
91 \\
68 \\
75\end{array}$ & $\begin{array}{l}38 \\
\mathbf{4 2} \\
\mathbf{4 6} \\
\mathbf{3 6} \\
40 \\
\mathbf{4 2} \\
\mathbf{4 1} \\
36 \\
\mathbf{5 0} \\
\mathbf{4 6} \\
45 \\
48 \\
40 \\
30\end{array}$ & $\begin{array}{r}8 \\
6 \\
6 \\
13 \\
15 \\
17 \\
30 \\
17 \\
26 \\
24 \\
18 \\
25 \\
18 \\
6\end{array}$ \\
\hline
\end{tabular}


8. Dela ware River at Marcus Hook, Pa., 1950-65

\begin{tabular}{|c|c|c|c|c|c|c|c|c|c|c|c|c|c|c|c|c|c|c|c|c|c|}
\hline $\begin{array}{l}1950 \\
1951 \\
1952 \\
1953 \\
1954 \\
1955 \\
1956 \\
1958 \\
1959 \\
1960 \\
1961 \\
1962\end{array}$ & $\begin{array}{l}7.2 \\
7.5 \\
7.5 \\
7.1 \\
6.9 \\
6.9 \\
7.2 \\
7.7 \\
7.0 \\
6.8 \\
7.0 \\
6.9 \\
6.7 \\
7.1\end{array}$ & $\begin{array}{l}6.4 \\
6.6 \\
6.5 \\
6.7 \\
6.5 \\
6.4 \\
6.5 \\
6.3 \\
6.7 \\
6.1 \\
6.5 \\
6.5 \\
6.6 \\
6.4\end{array}$ & $\begin{array}{l}\text { 6.0 } \\
6.3 \\
5.7 \\
6.3 \\
5.7 \\
5.2 \\
6.0 \\
5.3 \\
5.5 \\
5.0 \\
6.0 \\
6.0 \\
5.6 \\
5.1\end{array}$ & $\begin{array}{r}1,000 \\
1,250 \\
1,750 \\
2,550 \\
2,870 \\
3,590 \\
694 \\
6,120 \\
370 \\
1,150 \\
393 \\
2,080 \\
1,200 \\
3,860\end{array}$ & $\begin{array}{r}\mathbf{3 1 3} \\
\mathbf{4 2 1} \\
342 \\
829 \\
998 \\
581 \\
310 \\
\mathbf{3 1 0} \\
\mathbf{3 3 0} \\
228 \\
\mathbf{4 9 9} \\
250 \\
565 \\
\mathbf{4 9 3} \\
1,700\end{array}$ & $\begin{array}{r}117 \\
92 \\
143 \\
147 \\
162 \\
180 \\
143 \\
201 \\
150 \\
139 \\
141 \\
126 \\
141 \\
117\end{array}$ & $\begin{array}{r}222 \\
872 \\
466 \\
802 \\
848 \\
1,110 \\
129 \\
1,940 \\
33 \\
250 \\
48 \\
560 \\
252 \\
1,460\end{array}$ & $\begin{array}{r}40 \\
86 \\
51 \\
214 \\
250 \\
124 \\
32 \\
663 \\
15 \\
88 \\
19 \\
120 \\
69 \\
518\end{array}$ & \begin{tabular}{r|}
5.7 \\
4.7 \\
5.2 \\
7.8 \\
8.6 \\
8.5 \\
6.5 \\
11 \\
11 \\
6.0 \\
7.4 \\
6.7 \\
5.8 \\
7.5 \\
6.1
\end{tabular} & $\begin{array}{r}123 \\
88 \\
63 \\
120 \\
85 \\
106 \\
130 \\
230 \\
124 \\
73 \\
119 \\
93 \\
88 \\
136\end{array}$ & $\begin{array}{l}51 \\
43 \\
41 \\
48 \\
55 \\
53 \\
56 \\
82 \\
57 \\
51 \\
55 \\
54 \\
42 \\
87\end{array}$ & $\begin{array}{l}24 \\
13 \\
14 \\
17 \\
21 \\
19 \\
16 \\
33 \\
18 \\
21 \\
20 \\
21 \\
26 \\
28\end{array}$ & $\begin{array}{l}81 \\
80 \\
82 \\
86 \\
80 \\
86 \\
80 \\
84 \\
82 \\
84 \\
81 \\
83 \\
79 \\
82\end{array}$ & $\begin{array}{l}59 \\
59 \\
58 \\
59 \\
59 \\
60 \\
58 \\
58 \\
57 \\
60 \\
61 \\
60 \\
59 \\
58\end{array}$ & $\begin{array}{l}\mathbf{3 6} \\
\mathbf{3 5} \\
\mathbf{3 8} \\
\mathbf{3 8} \\
\mathbf{3 4} \\
\mathbf{3 8} \\
\mathbf{3 6} \\
\mathbf{3 8} \\
\mathbf{3 7} \\
\mathbf{3 6} \\
\mathbf{3 9} \\
\mathbf{3 6} \\
\mathbf{3 5} \\
\mathbf{3 4}\end{array}$ & $\begin{array}{r}10.6 \\
10.7 \\
10.7 \\
7.6 \\
9.4 \\
9.0 \\
7.6 \\
7.9 \\
8.8 \\
7.9 \\
9.6 \\
10.7 \\
8.3 \\
8.6\end{array}$ & $\begin{array}{l}4.6 \\
4.9 \\
5.4 \\
4.2 \\
4.7 \\
5.0 \\
5.0 \\
4.7 \\
5.8 \\
4.8 \\
4.6 \\
5.1 \\
4.4 \\
8.9\end{array}$ & $\begin{array}{l}1.0 \\
1.6 \\
1.0 \\
1.3 \\
1.9 \\
1.4 \\
2.3 \\
2.5 \\
2.0 \\
2.3 \\
2.2 \\
2.0 \\
1.3 \\
1.4\end{array}$ & $\begin{array}{l}84 \\
87 \\
82 \\
59 \\
70 \\
76 \\
63 \\
58 \\
71 \\
71 \\
77 \\
82 \\
69 \\
72\end{array}$ & $\begin{array}{l}39 \\
43 \\
47 \\
38 \\
42 \\
45 \\
46 \\
43 \\
47 \\
45 \\
44 \\
47 \\
39 \\
35\end{array}$ & $\begin{array}{l}11 \\
18 \\
12 \\
16 \\
20 \\
17 \\
25 \\
33 \\
25 \\
27 \\
27 \\
25 \\
15 \\
16\end{array}$ \\
\hline
\end{tabular}

1 A verages of 5-point cross-section samples collected monthly January 1950-December 1963. The figures tabulated under maximum, mean, median, or minimum represent the averages of cross sections. The measurements represented in the pH tables are the median of 5 top samples and 3 to 5 bottom samples; in the specific conductance tables, the

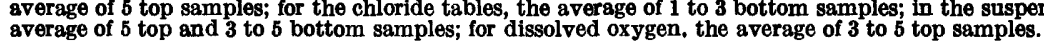


TABLE 11.-Monthly maximum, mean, and minimum of water-quality parameters, Delaware River, 1949-63 ${ }^{1}$

\begin{tabular}{|c|c|c|c|c|c|c|c|c|c|c|c|c|c|c|c|c|c|c|c|c|c|}
\hline \multirow{3}{*}{ Month } & \multirow{2}{*}{\multicolumn{3}{|c|}{$\begin{array}{c}\text { Hydrogen ion } \\
\text { (pH) }\end{array}$}} & \multirow{2}{*}{\multicolumn{3}{|c|}{$\begin{array}{l}\text { Specific conductance } \\
\text { (micromhos at } 25^{\circ} \mathrm{C} \text { ) }\end{array}$}} & \multirow{2}{*}{\multicolumn{3}{|c|}{ Chloride (ppm) }} & \multirow{2}{*}{\multicolumn{3}{|c|}{$\begin{array}{c}\text { Suspended sediment } \\
(\mathrm{ppm})\end{array}$}} & \multirow{2}{*}{\multicolumn{3}{|c|}{ Temperature $\left({ }^{\circ} \mathrm{F}\right)$}} & \multicolumn{6}{|c|}{ Dissolved oxygen } \\
\hline & & & & & & & & & & & & & & & & \multicolumn{3}{|c|}{ Parts per million } & \multicolumn{3}{|c|}{ Percent saturation } \\
\hline & $\operatorname{Max}$ & Median & Min & $\operatorname{Max}$ & Mean & Min & Max & Mean & Min & Max & Mean & Min & Max & Mean & Min & Max & Mean & Min & Max & Mean & Min \\
\hline \multicolumn{22}{|c|}{ 1. Dela ware River at Bristol-Burlington Bridge, 1949-63 } \\
\hline $\begin{array}{l}\text { August } \\
\text { September... } \\
\text { October-.... } \\
\text { November-... } \\
\text { December-... }\end{array}$ & \begin{tabular}{|r}
7.3 \\
7.3 \\
7.4 \\
7.3 \\
7.3 \\
7.4 \\
7.5 \\
7.5 \\
7.8 \\
7.5 \\
7.7 \\
7.5
\end{tabular} & $\begin{array}{l}6.9 \\
7.1 \\
7.0 \\
6.9 \\
7.0 \\
6.9 \\
7.0 \\
6.9 \\
7.0 \\
7.0 \\
6.9 \\
7.1\end{array}$ & $\begin{array}{l}6.4 \\
6.2 \\
6.5 \\
6.6 \\
6.6 \\
6.6 \\
6.7 \\
6.2 \\
6.6 \\
6.7 \\
6.5 \\
6.4\end{array}$ & $\begin{array}{l}172 \\
188 \\
216 \\
139 \\
156 \\
204 \\
207 \\
255 \\
256 \\
242 \\
266 \\
185\end{array}$ & $\begin{array}{r}140 \\
144 \\
131 \\
98 \\
115 \\
146 \\
176 \\
193 \\
195 \\
198 \\
181 \\
168\end{array}$ & $\begin{array}{r}97 \\
104 \\
85 \\
60 \\
88 \\
84 \\
124 \\
141 \\
136 \\
136 \\
82 \\
105\end{array}$ & $\begin{array}{c}10.1 \\
8.6 \\
12 \\
5.3 \\
8 \\
10 \\
10 \\
17 \\
16 \\
16 \\
14 \\
8.7\end{array}$ & $\begin{array}{l}6.2 \\
6.1 \\
5.6 \\
3.9 \\
4.3 \\
5.8 \\
7.4 \\
9.1 \\
8.7 \\
9.6 \\
8.8 \\
6.2\end{array}$ & \begin{tabular}{|l|}
3.0 \\
3.3 \\
3.1 \\
2.3 \\
2.9 \\
2.2 \\
4.1 \\
4.1 \\
3.2 \\
4.2 \\
2.7 \\
3.7
\end{tabular} & $\begin{array}{r}213 \\
238 \\
332 \\
216 \\
192 \\
113 \\
189 \\
64 \\
205 \\
170 \\
38 \\
208\end{array}$ & $\begin{array}{l}\mathbf{4 5} \\
54 \\
\mathbf{4 5} \\
54 \\
50 \\
34 \\
\mathbf{4 1} \\
\mathbf{3 0} \\
\mathbf{4 1} \\
\mathbf{4 4} \\
\mathbf{2 2} \\
\mathbf{4 7}\end{array}$ & $\begin{array}{r}7 \\
10 \\
8 \\
7 \\
11 \\
9 \\
14 \\
15 \\
7 \\
8 \\
12 \\
9\end{array}$ & $\begin{array}{l}39 \\
41 \\
43 \\
52 \\
67 \\
85 \\
86 \\
85 \\
85 \\
71 \\
60 \\
45\end{array}$ & $\begin{array}{l}36 \\
37 \\
40 \\
48 \\
60 \\
72 \\
80 \\
80 \\
76 \\
64 \\
53 \\
42\end{array}$ & $\begin{array}{l}\mathbf{3 3} \\
\mathbf{3 4} \\
\mathbf{3 4} \\
\mathbf{4 3} \\
\mathbf{5 2} \\
65 \\
\mathbf{7 4} \\
76 \\
70 \\
\mathbf{4 9} \\
\mathbf{4 4} \\
\mathbf{3 4}\end{array}$ & \begin{tabular}{|r|r|}
12.1 \\
12.6 \\
13.2 \\
11.6 \\
98.8 \\
8.3 \\
8.2 \\
8.1 \\
88.0 \\
9.3 \\
11.4 \\
13.3
\end{tabular} & $\begin{array}{r}10.9 \\
11.3 \\
11.2 \\
10.3 \\
8.9 \\
6.8 \\
5.5 \\
5.7 \\
5.8 \\
7.7 \\
9.1 \\
10.8\end{array}$ & $\begin{array}{l}8.7 \\
7.9 \\
8.4 \\
6.7 \\
8.0 \\
3.2 \\
2.3 \\
3.8 \\
2.6 \\
4.4 \\
7.0 \\
6.3\end{array}$ & $\begin{array}{r}99 \\
95 \\
104 \\
98 \\
97 \\
93 \\
102 \\
101 \\
88 \\
93 \\
98 \\
106\end{array}$ & $\begin{array}{l}80 \\
84 \\
86 \\
88 \\
88 \\
77 \\
67 \\
71 \\
72 \\
79 \\
81 \\
85\end{array}$ & $\begin{array}{l}61 \\
57 \\
63 \\
56 \\
81 \\
38 \\
30 \\
49 \\
31 \\
47 \\
68 \\
50\end{array}$ \\
\hline \multicolumn{22}{|c|}{ 2. Dela ware River at Torresdale intake, Philadelphia, Pa., 1949-63 } \\
\hline 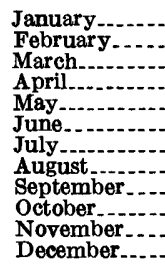 & $\begin{array}{l}7.2 \\
7.1 \\
7.3 \\
7.3 \\
7.4 \\
7.1 \\
7.2 \\
7.4 \\
7.1 \\
7.1 \\
7.2 \\
8.7\end{array}$ & $\begin{array}{l}6.8 \\
6.8 \\
6.9 \\
6.9 \\
6.9 \\
6.9 \\
6.9 \\
6.8 \\
6.9 \\
6.8 \\
6.9 \\
7.0\end{array}$ & $\begin{array}{l}6.2 \\
6.5 \\
6.4 \\
6.6 \\
6.5 \\
6.6 \\
6.6 \\
6.1 \\
6.3 \\
6.4 \\
6.5 \\
6.4\end{array}$ & $\begin{array}{l}197 \\
199 \\
214 \\
137 \\
170 \\
194 \\
211 \\
273 \\
278 \\
273 \\
256 \\
198\end{array}$ & $\begin{array}{l}144 \\
141 \\
130 \\
100 \\
115 \\
145 \\
169 \\
190 \\
191 \\
201 \\
184 \\
145\end{array}$ & $\begin{array}{r}102 \\
112 \\
85 \\
57 \\
86 \\
91 \\
114 \\
155 \\
141 \\
146 \\
96 \\
103\end{array}$ & $\begin{array}{r}10 \\
11 \\
13 \\
6 \\
9 \\
9 \\
10 \\
11 \\
20 \\
17 \\
26 \\
18 \\
13\end{array}$ & $\begin{array}{r}6.7 \\
6.0 \\
5.6 \\
3.7 \\
4.8 \\
6.0 \\
7.6 \\
9.7 \\
9.6 \\
11.2 \\
9.7 \\
7.0\end{array}$ & $\begin{array}{l}4.0 \\
2.7 \\
2.0 \\
2.0 \\
2.5 \\
2.0 \\
4.0 \\
4.0 \\
5.0 \\
4.0 \\
3.0 \\
4.0\end{array}$ & $\begin{array}{r}143 \\
122 \\
245 \\
101 \\
76 \\
76 \\
109 \\
48 \\
85 \\
109 \\
139 \\
120\end{array}$ & $\begin{array}{l}52 \\
49 \\
54 \\
40 \\
28 \\
30 \\
28 \\
29 \\
29 \\
33 \\
39 \\
42\end{array}$ & $\begin{array}{r}13 \\
12 \\
14 \\
10 \\
14 \\
13 \\
9 \\
13 \\
10 \\
7 \\
9 \\
13\end{array}$ & $\begin{array}{l}39 \\
41 \\
43 \\
53 \\
65 \\
83 \\
85 \\
85 \\
86 \\
72 \\
62 \\
47\end{array}$ & $\begin{array}{l}36 \\
37 \\
39 \\
48 \\
60 \\
72 \\
79 \\
80 \\
76 \\
65 \\
53 \\
42\end{array}$ & $\begin{array}{l}\mathbf{3 3} \\
\mathbf{3 4} \\
\mathbf{3 5} \\
\mathbf{4 3} \\
53 \\
65 \\
\mathbf{7 5} \\
\mathbf{7 5} \\
\mathbf{6 8} \\
\mathbf{4 8} \\
\mathbf{4 5} \\
\mathbf{3 5}\end{array}$ & \begin{tabular}{|r}
12.1 \\
12.9 \\
13.4 \\
11.9 \\
9.7 \\
7.7 \\
8.2 \\
7.1 \\
7.5 \\
9.3 \\
10.7 \\
12.4
\end{tabular} & $\begin{array}{r}10.5 \\
10.9 \\
10.9 \\
10.1 \\
8.7 \\
6.2 \\
5.3 \\
5.2 \\
5.5 \\
6.6 \\
8.5 \\
10.2\end{array}$ & $\begin{array}{l}7.4 \\
7.4 \\
6.9 \\
8.7 \\
7.8 \\
3.6 \\
2.3 \\
3.5 \\
\mathbf{3 . 1} \\
\mathbf{3 . 3} \\
5.3 \\
\mathbf{5 . 1}\end{array}$ & $\begin{array}{r}91 \\
97 \\
104 \\
98 \\
94 \\
83 \\
97 \\
92 \\
95 \\
97 \\
95 \\
98\end{array}$ & $\begin{array}{l}77 \\
80 \\
82 \\
86 \\
85 \\
70 \\
64 \\
64 \\
66 \\
69 \\
79 \\
81\end{array}$ & $\begin{array}{l}52 \\
54 \\
52 \\
76 \\
78 \\
34 \\
29 \\
43 \\
37 \\
38 \\
50 \\
41\end{array}$ \\
\hline
\end{tabular}


3. Dela ware Rdver at Lehigh Avenue, Philadelphia, Pa., 1949-63

\begin{tabular}{|c|c|c|c|c|c|c|c|c|c|c|c|c|c|c|c|c|c|c|c|c|c|}
\hline 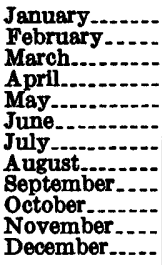 & $\begin{array}{l}7.6 \\
7.0 \\
7.4 \\
7.2 \\
7.1 \\
7.0 \\
7.0 \\
7.3 \\
6.9 \\
7.1 \\
7.1 \\
7.2\end{array}$ & $\begin{array}{l}6.7 \\
6.8 \\
6.8 \\
6.8 \\
6.8 \\
6.6 \\
6.8 \\
6.8 \\
6.7 \\
6.7 \\
6.7 \\
6.7\end{array}$ & $\begin{array}{l}6.2 \\
6.4 \\
6.2 \\
6.4 \\
6.4 \\
6.3 \\
6.5 \\
6.0 \\
6.5 \\
6.3 \\
6.3 \\
6.3\end{array}$ & $\begin{array}{l}265 \\
205 \\
251 \\
163 \\
178 \\
237 \\
287 \\
483 \\
443 \\
571 \\
455 \\
216\end{array}$ & $\begin{array}{l}162 \\
152 \\
137 \\
107 \\
125 \\
166 \\
205 \\
253 \\
257 \\
284 \\
258 \\
166\end{array}$ & $\begin{array}{r}118 \\
111 \\
84 \\
57 \\
89 \\
111 \\
135 \\
163 \\
162 \\
136 \\
115 \\
106\end{array}$ & $\begin{array}{c}14 \\
12 \\
10 \\
6.3 \\
9 \\
13 \\
22 \\
67 \\
61 \\
97 \\
65 \\
15\end{array}$ & $\begin{array}{r}8.5 \\
7.5 \\
6.9 \\
4.2 \\
5.0 \\
7.9 \\
11.4 \\
18 \\
18 \\
27 \\
21 \\
9.2\end{array}$ & $\begin{array}{l}4.0 \\
4.3 \\
2.5 \\
2.5 \\
2.5 \\
3.3 \\
5.5 \\
7.0 \\
6.5 \\
4.5 \\
4.0 \\
4.0\end{array}$ & $\begin{array}{r}115 \\
121 \\
245 \\
101 \\
76 \\
76 \\
109 \\
48 \\
85 \\
109 \\
139 \\
120\end{array}$ & $\begin{array}{l}48 \\
48 \\
55 \\
38 \\
26 \\
31 \\
28 \\
28 \\
28 \\
31 \\
38 \\
42\end{array}$ & $\begin{array}{r}14 \\
15 \\
16 \\
13 \\
13 \\
13 \\
11 \\
13 \\
9 \\
7 \\
8 \\
17\end{array}$ & $\begin{array}{l}42 \\
41 \\
44 \\
52 \\
65 \\
84 \\
85 \\
83 \\
85 \\
73 \\
65 \\
48\end{array}$ & $\begin{array}{l}36 \\
37 \\
39 \\
47 \\
59 \\
72 \\
79 \\
80 \\
77 \\
66 \\
55 \\
43\end{array}$ & $\begin{array}{l}34 \\
33 \\
35 \\
44 \\
52 \\
67 \\
76 \\
76 \\
73 \\
50 \\
47 \\
37\end{array}$ & $\begin{array}{r}12.0 \\
12.4 \\
12.3 \\
11.0 \\
9.7 \\
8.7 \\
4.1 \\
5.5 \\
6.6 \\
6.5 \\
10.2 \\
12.7\end{array}$ & $\begin{array}{r}9.6 \\
10.4 \\
9.9 \\
9.5 \\
7.2 \\
3.8 \\
2.4 \\
2.2 \\
2.4 \\
3.1 \\
4.9 \\
8.5\end{array}$ & $\begin{array}{l}7.2 \\
7.6 \\
7.7 \\
7.6 \\
5.5 \\
1.3 \\
.5 \\
.2 \\
.7 \\
.7 \\
.9 \\
2.1\end{array}$ & $\begin{array}{r}90 \\
94 \\
100 \\
92 \\
82 \\
72 \\
49 \\
73 \\
79 \\
57 \\
86 \\
101\end{array}$ & $\begin{array}{l}65 \\
77 \\
76 \\
81 \\
71 \\
39 \\
29 \\
28 \\
29 \\
34 \\
46 \\
67\end{array}$ & $\begin{array}{r}52 \\
55 \\
60 \\
64 \\
55 \\
15 \\
7 \\
3 \\
8 \\
8 \\
9 \\
18\end{array}$ \\
\hline \multicolumn{22}{|c|}{ 4. Delaware River at Benjamin Franklin Bridge, 1949-63 } \\
\hline 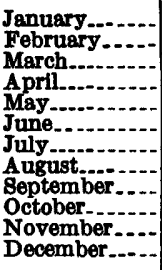 & $\begin{array}{l}7.7 \\
7.2 \\
7.7 \\
7.2 \\
7.1 \\
7.3 \\
7.4 \\
7.5 \\
7.6 \\
7.4 \\
7.5 \\
7.2\end{array}$ & $\begin{array}{l}6.7 \\
6.8 \\
6.8 \\
6.8 \\
6.8 \\
6.6 \\
6.8 \\
6.7 \\
6.8 \\
6.7 \\
6.8 \\
6.9\end{array}$ & $\begin{array}{l}6.1 \\
6.4 \\
6.2 \\
6.4 \\
6.4 \\
6.3 \\
6.4 \\
6.1 \\
6.3 \\
6.3 \\
6.3 \\
6.0\end{array}$ & $\begin{array}{l}285 \\
222 \\
263 \\
166 \\
193 \\
242 \\
299 \\
503 \\
876 \\
647 \\
516 \\
231\end{array}$ & $\begin{array}{l}172 \\
154 \\
156 \\
111 \\
131 \\
172 \\
219 \\
261 \\
313 \\
311 \\
283 \\
175\end{array}$ & $\begin{array}{r}122 \\
85 \\
102 \\
61 \\
90 \\
113 \\
141 \\
1166 \\
169 \\
135 \\
117 \\
110\end{array}$ & $\begin{array}{c}20 \\
13 \\
18 \\
7.0 \\
9.0 \\
14 \\
22 \\
74 \\
172 \\
115 \\
72 \\
16\end{array}$ & $\begin{array}{l}9.9 \\
8.4 \\
8.3 \\
5.1 \\
5.9 \\
9.0 \\
12 \\
20 \\
32 \\
31 \\
25 \\
9.9\end{array}$ & $\begin{array}{l}5.7 \\
3.5 \\
4.6 \\
3.3 \\
3.5 \\
4.1 \\
5.7 \\
6.8 \\
8.1 \\
5.0 \\
5.1 \\
6.1\end{array}$ & $\begin{array}{r}99 \\
112 \\
259 \\
104 \\
79 \\
63 \\
89 \\
39 \\
89 \\
109 \\
94 \\
122\end{array}$ & $\begin{array}{l}51 \\
49 \\
57 \\
44 \\
38 \\
29 \\
33 \\
27 \\
37 \\
40 \\
41 \\
49\end{array}$ & \begin{tabular}{r|}
22 \\
13 \\
22 \\
22 \\
4 \\
13 \\
18 \\
15 \\
13 \\
9 \\
10 \\
24
\end{tabular} & $\begin{array}{l}41 \\
43 \\
44 \\
52 \\
65 \\
83 \\
83 \\
84 \\
83 \\
73 \\
64 \\
48\end{array}$ & $\begin{array}{l}37 \\
37 \\
39 \\
48 \\
59 \\
71 \\
79 \\
81 \\
77 \\
66 \\
55 \\
44\end{array}$ & $\begin{array}{l}34 \\
33 \\
36 \\
44 \\
52 \\
66 \\
76 \\
77 \\
69 \\
50 \\
\mathbf{4 7} \\
\mathbf{3 8}\end{array}$ & $\begin{array}{r}11.6 \\
12.5 \\
12.4 \\
11.1 \\
8.0 \\
6.5 \\
5.2 \\
3.4 \\
5.8 \\
5.9 \\
10.2 \\
10.5\end{array}$ & $\begin{array}{l}8.8 \\
9.5 \\
9.6 \\
9.2 \\
6.6 \\
3.3 \\
2.0 \\
1.9 \\
1.7 \\
2.5 \\
4.5 \\
7.9\end{array}$ & $\begin{array}{r}6.6 \\
7.7 \\
7.6 \\
7.2 \\
5.3 \\
1.1 \\
.6 \\
.0 \\
.0 \\
.4 \\
.1 \\
3.5\end{array}$ & $\begin{array}{r}\mathbf{8 8} \\
95 \\
100 \\
93 \\
76 \\
74 \\
\mathbf{4 4} \\
41 \\
69 \\
63 \\
90 \\
83\end{array}$ & $\begin{array}{l}65 \\
70 \\
73 \\
78 \\
65 \\
37 \\
22 \\
23 \\
20 \\
26 \\
41 \\
65\end{array}$ & $\begin{array}{r}48 \\
56 \\
59 \\
61 \\
53 \\
12 \\
7 \\
0 \\
0 \\
4 \\
1 \\
29\end{array}$ \\
\hline \multicolumn{22}{|c|}{ 5. Dela ware River at Wharton Street, Philadelphia, 1949-63 } \\
\hline 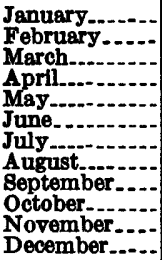 & $\begin{array}{l}7.5 \\
7.0 \\
7.1 \\
7.0 \\
7.0 \\
6.8 \\
7.0 \\
6.9 \\
6.9 \\
7.0 \\
7.1 \\
7.1\end{array}$ & $\begin{array}{l}6.6 \\
6.6 \\
6.6 \\
6.7 \\
6.7 \\
6.5 \\
6.7 \\
6.7 \\
6.6 \\
6.6 \\
6.6 \\
6.6\end{array}$ & $\begin{array}{l}6.0 \\
5.9 \\
6.3 \\
6.3 \\
6.3 \\
6.3 \\
6.4 \\
5.9 \\
6.4 \\
6.3 \\
6.3 \\
6.0\end{array}$ & $\begin{array}{l}238 \\
264 \\
295 \\
173 \\
193 \\
247 \\
292 \\
561 \\
692 \\
646 \\
753 \\
\mathbf{3 3 2}\end{array}$ & $\begin{array}{l}175 \\
170 \\
156 \\
112 \\
136 \\
181 \\
231 \\
283 \\
315 \\
318 \\
344 \\
193\end{array}$ & $\begin{array}{r}109 \\
123 \\
93 \\
68 \\
95 \\
117 \\
140 \\
189 \\
171 \\
155 \\
127 \\
115\end{array}$ & $\begin{array}{c}18 \\
17 \\
21 \\
9.0 \\
11 \\
15 \\
21 \\
89 \\
123 \\
116 \\
137 \\
29\end{array}$ & $\begin{array}{l}9.4 \\
9.6 \\
8.2 \\
4.8 \\
6.0 \\
9.1 \\
13 \\
25 \\
32 \\
30 \\
37 \\
12\end{array}$ & $\begin{array}{l}5.3 \\
4.3 \\
3.5 \\
2.0 \\
3.5 \\
4.0 \\
6.5 \\
8.5 \\
8.5 \\
6.5 \\
6.0 \\
4.7\end{array}$ & $\begin{array}{r}104 \\
93 \\
134 \\
80 \\
61 \\
35 \\
124 \\
124 \\
54 \\
65 \\
49 \\
99 \\
78\end{array}$ & $\begin{array}{l}41 \\
45 \\
47 \\
40 \\
30 \\
24 \\
38 \\
29 \\
29 \\
31 \\
38 \\
39\end{array}$ & $\begin{array}{r}17 \\
14 \\
16 \\
14 \\
11 \\
11 \\
16 \\
11 \\
6 \\
15 \\
12 \\
18\end{array}$ & $\begin{array}{l}45 \\
41 \\
43 \\
53 \\
63 \\
83 \\
84 \\
85 \\
84 \\
74 \\
66 \\
50\end{array}$ & $\begin{array}{l}37 \\
37 \\
40 \\
48 \\
60 \\
72 \\
79 \\
81 \\
78 \\
67 \\
56 \\
45\end{array}$ & $\begin{array}{l}34 \\
34 \\
37 \\
43 \\
54 \\
65 \\
75 \\
77 \\
69 \\
50 \\
47 \\
40\end{array}$ & $\begin{array}{r}11.5 \\
11.6 \\
11.4 \\
10.8 \\
8.8 \\
6.3 \\
3.3 \\
3.0 \\
4.2 \\
3.8 \\
9.1 \\
11.5\end{array}$ & $\begin{array}{l}8.9 \\
9.3 \\
8.8 \\
8.9 \\
5.6 \\
2.3 \\
1.7 \\
1.6 \\
1.4 \\
2.0 \\
3.1 \\
6.5\end{array}$ & $\begin{array}{r}5.8 \\
6.5 \\
6.4 \\
6.3 \\
3.4 \\
1.0 \\
.1 \\
.0 \\
.0 \\
.0 \\
.0 \\
2.5\end{array}$ & $\begin{array}{l}86 \\
91 \\
86 \\
90 \\
85 \\
65 \\
39 \\
37 \\
50 \\
39 \\
75 \\
91\end{array}$ & $\begin{array}{l}69 \\
69 \\
67 \\
73 \\
56 \\
26 \\
21 \\
20 \\
17 \\
22 \\
29 \\
53\end{array}$ & $\begin{array}{r}42 \\
46 \\
48 \\
56 \\
34 \\
11 \\
1 \\
0 \\
0 \\
0 \\
0 \\
21\end{array}$ \\
\hline
\end{tabular}

See footnote at end of table. 
TABLE 11.-Monthly maximum, mean, and minimum of water-quality parameters, Delaware River, 1949-63 1-Continued

\begin{tabular}{|c|c|c|c|c|c|c|c|c|c|c|c|c|c|c|c|c|c|c|c|c|c|}
\hline \multirow{3}{*}{ Month } & \multirow{2}{*}{\multicolumn{3}{|c|}{$\begin{array}{l}\text { Hydrogen ion } \\
\text { (pH) }\end{array}$}} & \multirow{2}{*}{\multicolumn{3}{|c|}{$\begin{array}{l}\text { Specific conductance } \\
\text { (micromhos at } 25^{\circ} \mathrm{C} \text { ) }\end{array}$}} & \multirow{2}{*}{\multicolumn{3}{|c|}{ Chloride (ppm) }} & \multirow{2}{*}{\multicolumn{3}{|c|}{$\begin{array}{c}\text { Suspended sediment } \\
(\mathrm{ppm})\end{array}$}} & \multirow{2}{*}{\multicolumn{3}{|c|}{ Temperature $\left({ }^{\circ} \mathrm{F}\right)$}} & \multicolumn{6}{|c|}{ Dissolved oxygen } \\
\hline & & & & & & & & & & & & & & & & \multicolumn{3}{|c|}{ Parts per million } & \multicolumn{3}{|c|}{ Percent saturation } \\
\hline & Max & Median & Min & Max & Mean & Min & Max & Mean & Min & Max & Mean & Min & $\operatorname{Max}$ & Mean & Min & $\operatorname{Max}$ & Mean & Min & Max & Mean & Min \\
\hline \multicolumn{22}{|c|}{ 6. Dela ware River at League Island, Philadelphin, Pa., 1949-63 } \\
\hline 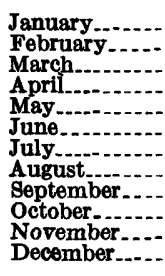 & $\begin{array}{l}7.5 \\
7.0 \\
7.0 \\
7.0 \\
7.6 \\
6.8 \\
6.9 \\
6.9 \\
6.9 \\
7.1 \\
7.0 \\
6.9\end{array}$ & $\begin{array}{l}6.5 \\
6.5 \\
6.6 \\
6.7 \\
6.6 \\
6.5 \\
6.7 \\
6.6 \\
6.6 \\
6.6 \\
6.6 \\
6.4\end{array}$ & $\begin{array}{l}5.9 \\
5.9 \\
6.2 \\
6.2 \\
6.2 \\
6.2 \\
6.3 \\
6.0 \\
6.2 \\
6.3 \\
6.2 \\
6.1\end{array}$ & $\begin{array}{r}312 \\
318 \\
322 \\
184 \\
229 \\
286 \\
350 \\
1,020 \\
\mathbf{1 , 4 5} \\
1,180 \\
1,060 \\
\mathbf{4 3 6}\end{array}$ & $\begin{array}{l}191 \\
188 \\
168 \\
126 \\
153 \\
202 \\
256 \\
358 \\
404 \\
446 \\
458 \\
220\end{array}$ & $\begin{array}{l}130 \\
140 \\
101 \\
75 \\
101 \\
115 \\
182 \\
192 \\
194 \\
156 \\
153 \\
116\end{array}$ & $\begin{array}{l}22 \\
22 \\
22 \\
9.0 \\
12 \\
17 \\
33 \\
220 \\
182 \\
275 \\
206 \\
48\end{array}$ & $\begin{array}{l}11 \\
12 \\
9.1 \\
5.6 \\
7.4 \\
9.8 \\
16 \\
45 \\
52 \\
57 \\
64 \\
16\end{array}$ & $\begin{array}{r}5.3 \\
6.7 \\
4.0 \\
3.0 \\
3.5 \\
1.7 \\
9.0 \\
11 \\
9.2 \\
6.5 \\
7.0 \\
4.0\end{array}$ & $\begin{array}{r}100 \\
95 \\
177 \\
90 \\
44 \\
57 \\
82 \\
42 \\
51 \\
52 \\
102 \\
68\end{array}$ & $\begin{array}{l}44 \\
45 \\
50 \\
42 \\
22 \\
23 \\
30 \\
25 \\
25 \\
34 \\
39 \\
38\end{array}$ & $\begin{array}{r}16 \\
16 \\
21 \\
15 \\
10 \\
9 \\
12 \\
10 \\
7 \\
14 \\
12 \\
19\end{array}$ & $\begin{array}{l}46 \\
41 \\
43 \\
54 \\
64 \\
82 \\
84 \\
86 \\
84 \\
72 \\
66 \\
49\end{array}$ & $\begin{array}{l}38 \\
37 \\
40 \\
48 \\
60 \\
72 \\
79 \\
81 \\
78 \\
67 \\
56 \\
44\end{array}$ & $\begin{array}{l}34 \\
34 \\
38 \\
44 \\
54 \\
65 \\
76 \\
76 \\
69 \\
49 \\
48 \\
40\end{array}$ & $\begin{array}{r}11.0 \\
12.1 \\
10.8 \\
10.6 \\
7.6 \\
5.7 \\
3.3 \\
3.3 \\
3.3 \\
3.6 \\
7.7 \\
11.9\end{array}$ & $\begin{array}{l}8.1 \\
8.4 \\
8.6 \\
8.2 \\
4.4 \\
2.3 \\
1.9 \\
1.8 \\
1.7 \\
2.0 \\
3.0 \\
6.3\end{array}$ & $\begin{array}{r}5.4 \\
6.3 \\
6.1 \\
6.3 \\
1.8 \\
.9 \\
.1 \\
.2 \\
.0 \\
.1 \\
.2 \\
3.0\end{array}$ & $\begin{array}{l}86 \\
93 \\
84 \\
89 \\
72 \\
39 \\
40 \\
42 \\
39 \\
38 \\
73 \\
94\end{array}$ & $\begin{array}{l}60 \\
64 \\
64 \\
70 \\
45 \\
26 \\
24 \\
22 \\
20 \\
22 \\
28 \\
50\end{array}$ & $\begin{array}{r}39 \\
44 \\
45 \\
29 \\
18 \\
10 \\
10 \\
2 \\
0 \\
1 \\
2 \\
25\end{array}$ \\
\hline
\end{tabular}

7. Dela ware Rdver at Eddystone, Pa., 1949-63

\begin{tabular}{|c|c|c|c|c|c|c|c|c|c|c|c|c|c|c|c|c|c|c|c|c|c|}
\hline 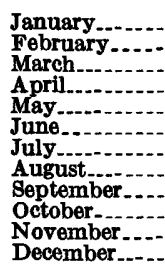 & $\begin{array}{l}7.4 \\
6.9 \\
7.0 \\
7.1 \\
6.9 \\
6.8 \\
6.9 \\
7.0 \\
7.0 \\
77.1 \\
7.0 \\
7.2\end{array}$ & $\begin{array}{l}6.4 \\
6.5 \\
6.6 \\
6.8 \\
6.6 \\
6.5 \\
6.6 \\
6.5 \\
6.5 \\
6.5 \\
6.5 \\
6.4\end{array}$ & $\begin{array}{l}6.0 \\
6.0 \\
6.2 \\
6.2 \\
6.2 \\
6.2 \\
6.2 \\
6.0 \\
6.3 \\
6.0 \\
6.2 \\
6.0\end{array}$ & $\begin{array}{r}972 \\
657 \\
342 \\
198 \\
271 \\
329 \\
830 \\
\mathbf{3}, 360 \\
2,720 \\
\mathbf{3}, 620 \\
\mathbf{3}, 410 \\
\mathbf{1 ,}, 680\end{array}$ & $\begin{array}{l}271 \\
247 \\
196 \\
143 \\
173 \\
221 \\
330 \\
666 \\
779 \\
973 \\
947 \\
362\end{array}$ & $\begin{array}{l}144 \\
145 \\
118 \\
78 \\
120 \\
126 \\
215 \\
230 \\
202 \\
160 \\
175 \\
151\end{array}$ & $\begin{array}{r}185 \\
105 \\
26 \\
10 \\
14 \\
28 \\
165 \\
920 \\
723 \\
972 \\
955 \\
297\end{array}$ & $\begin{array}{c}23 \\
19 \\
10 \\
6.7 \\
8.4 \\
14 \\
34 \\
145 \\
166 \\
227 \\
221 \\
50\end{array}$ & $\begin{array}{c}6.3 \\
6.0 \\
4.5 \\
4.0 \\
5.0 \\
4.0 \\
12 \\
14 \\
9.7 \\
18 \\
7.3 \\
7.0\end{array}$ & $\begin{array}{r}205 \\
119 \\
161 \\
82 \\
44 \\
70 \\
57 \\
70 \\
120 \\
101 \\
203 \\
93\end{array}$ & $\begin{array}{l}79 \\
71 \\
73 \\
55 \\
31 \\
32 \\
34 \\
37 \\
40 \\
50 \\
57 \\
50\end{array}$ & $\begin{array}{l}25 \\
19 \\
31 \\
22 \\
16 \\
12 \\
11 \\
16 \\
12 \\
24 \\
24 \\
23\end{array}$ & $\begin{array}{l}49 \\
41 \\
43 \\
54 \\
64 \\
82 \\
83 \\
86 \\
85 \\
72 \\
65 \\
50\end{array}$ & $\begin{array}{l}38 \\
38 \\
38 \\
49 \\
60 \\
72 \\
80 \\
81 \\
78 \\
67 \\
56 \\
45\end{array}$ & $\begin{array}{l}34 \\
34 \\
37 \\
44 \\
65 \\
65 \\
77 \\
76 \\
69 \\
48 \\
50 \\
41\end{array}$ & $\begin{array}{r}10.5 \\
11.4 \\
11.2 \\
10.5 \\
6.6 \\
5.2 \\
4.2 \\
3.5 \\
3.3 \\
4.0 \\
5.8 \\
10.6\end{array}$ & $\begin{array}{l}7.8 \\
7.8 \\
7.9 \\
7.8 \\
4.0 \\
2.5 \\
2.3 \\
2.2 \\
2.0 \\
2.2 \\
3.5 \\
5.7\end{array}$ & $\begin{array}{r}6.3 \\
5.9 \\
5.4 \\
3.6 \\
1.8 \\
1.0 \\
.8 \\
.5 \\
.5 \\
.7 \\
.6 \\
1.5\end{array}$ & $\begin{array}{l}78 \\
86 \\
86 \\
91 \\
64 \\
57 \\
52 \\
43 \\
40 \\
37 \\
52 \\
85\end{array}$ & $\begin{array}{l}58 \\
58 \\
62 \\
69 \\
39 \\
29 \\
29 \\
27 \\
24 \\
24 \\
33 \\
47\end{array}$ & $\begin{array}{r}41 \\
43 \\
43 \\
44 \\
18 \\
11 \\
10 \\
6 \\
6 \\
8 \\
6 \\
13\end{array}$ \\
\hline
\end{tabular}


8. Delaware River at Mareus Hook, Pa., 1949-63

\begin{tabular}{|c|c|c|c|c|c|c|c|c|c|c|c|c|c|c|c|c|c|c|c|c|c|}
\hline 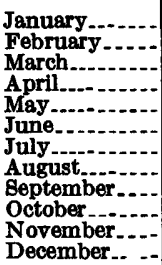 & $\begin{array}{l}7.7 \\
7.1 \\
7.5 \\
7.1 \\
7.1 \\
6.8 \\
6.9 \\
7.2 \\
7.5 \\
7.2 \\
7.4 \\
7.2\end{array}$ & $\begin{array}{l}6.5 \\
6.5 \\
6.7 \\
6.7 \\
6.6 \\
6.4 \\
6.4 \\
6.4 \\
6.5 \\
6.4 \\
6.4 \\
6.6\end{array}$ & $\begin{array}{l}5.5 \\
6.0 \\
6.1 \\
5.4 \\
5.9 \\
5.0 \\
5.2 \\
5.5 \\
5.9 \\
5.1 \\
6.0 \\
5.7\end{array}$ & $\begin{array}{r}4,300 \\
2,380 \\
\mathbf{4 6 2} \\
201 \\
315 \\
979 \\
2,110 \\
5.810 \\
5,370 \\
6,500 \\
5,970 \\
\mathbf{3}, 730\end{array}$ & $\begin{array}{r}\mathbf{5 7 2} \\
\mathbf{3 9 4} \\
207 \\
\mathbf{1 5 7} \\
\mathbf{1 9 4} \\
\mathbf{3 2 5} \\
\mathbf{5 9 9} \\
\mathbf{1 , 3 4 0} \\
\mathbf{1}, \mathbf{3 4 0} \\
\mathbf{1 , 8 4 0} \\
\mathbf{1 , 7 7 0} \\
\mathbf{6 2 9}\end{array}$ & \begin{tabular}{r|}
156 \\
158 \\
126 \\
89 \\
138 \\
139 \\
224 \\
226 \\
207 \\
169 \\
194 \\
139
\end{tabular} & $\begin{array}{r}1,460 \\
43 \\
43 \\
11 \\
16 \\
216 \\
530 \\
1,720 \\
1,560 \\
1,940 \\
1,920 \\
1,030\end{array}$ & $\begin{array}{c}138 \\
17 \\
12 \\
7.8 \\
9.7 \\
40 \\
115 \\
349 \\
344 \\
581 \\
515 \\
153\end{array}$ & $\begin{array}{rl}7.8 & 7.8 \\
6.2 \\
6.2 \\
4.7 \\
5.2 \\
5.2 \\
13 \\
14 \\
10 \\
7.7 \\
8.5 \\
7.3\end{array}$ & $\begin{array}{r}136 \\
124 \\
114 \\
78 \\
64 \\
59 \\
67 \\
94 \\
130 \\
143 \\
230 \\
85\end{array}$ & $\begin{array}{l}77 \\
73 \\
69 \\
51 \\
39 \\
33 \\
36 \\
49 \\
44 \\
64 \\
71 \\
60\end{array}$ & $\begin{array}{l}33 \\
27 \\
38 \\
34 \\
17 \\
19 \\
13 \\
18 \\
14 \\
27 \\
39 \\
34\end{array}$ & $\begin{array}{l}46 \\
41 \\
45 \\
55 \\
64 \\
83 \\
84 \\
86 \\
86 \\
73 \\
64 \\
60\end{array}$ & $\begin{array}{l}38 \\
39 \\
41 \\
49 \\
60 \\
72 \\
80 \\
81 \\
77 \\
67 \\
56 \\
46\end{array}$ & $\begin{array}{l}34 \\
34 \\
36 \\
45 \\
55 \\
65 \\
76 \\
77 \\
69 \\
47 \\
50 \\
41\end{array}$ & $\begin{array}{r}9.6 \\
10.7 \\
10.7 \\
1.1 \\
6.7 \\
4.6 \\
3.6 \\
3.1 \\
4.7 \\
6.3 \\
5.2 \\
10.6\end{array}$ & $\begin{array}{l}7.6 \\
7.8 \\
8.1 \\
7.8 \\
4.2 \\
2.7 \\
2.3 \\
2.1 \\
2.3 \\
2.9 \\
3.7 \\
6.1\end{array}$ & $\begin{array}{l}6.0 \\
6.3 \\
6.3 \\
5.6 \\
1.9 \\
1.3 \\
1.0 \\
1.0 \\
1.0 \\
1.0 \\
1.2 \\
2.7\end{array}$ & $\begin{array}{l}75 \\
82 \\
85 \\
87 \\
64 \\
51 \\
43 \\
39 \\
55 \\
54 \\
48 \\
84\end{array}$ & $\begin{array}{l}56 \\
59 \\
62 \\
67 \\
31 \\
30 \\
29 \\
26 \\
28 \\
30 \\
35 \\
51\end{array}$ & $\begin{array}{l}43 \\
\mathbf{4 7} \\
46 \\
50 \\
20 \\
15 \\
12 \\
12 \\
12 \\
11 \\
12 \\
43\end{array}$ \\
\hline
\end{tabular}

median, or minimum represent the sverace of cross sections. The measurements represented in the pH tables are the median of 5 top samples and

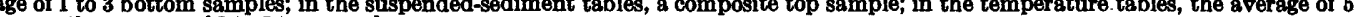
top and 3 to 5 bottom samples; for dissolved oxygen, the average of 3 to 5 top samples. 
micromhos; however, when the conductance exceeds 600 micromhos (which it did in nearly one-quarter of the samples), the conductance on the New Jersey side often exceeds that on the Pennsylvania side.

Because salt water is heavier than fresh water, ocean water may move up the estuary along the river bottom with the fresher water overriding the tongue of salt water and eroding it. This overriding happens in some parts of the estuary at some times, but in the river between Trenton and Marcus Hook such a salt tongue has not been observed. The salinity of the bottom samples at Marcus Hook is generally 5-10 percent greater than that of the top samples, but at upstream locations there is no significant difference in salinity between the top and bottom water. Occasionally top samples will have a slightly greater salinity than bottom samples. This salinity is presumably a temporary result of salt water, which is sometimes warmer and therefore, less dense than the cooler bottom water.

In any cross section the temperature variations are generally less than $1^{\circ} \mathrm{F}$. Top and bottom samples normally have the same $\mathrm{pH}$, within $0.2 \mathrm{pH}$ units, but occasionally large differences have been observed. The bottom samples on the right and left sides most frequently deviate in $\mathrm{pH}$ from the average for the cross section; this deviation is possibly the effect of pollution, tributary streams, or ground water inflow.

During most of the period covered by this report (1949-63), dissolved oxygen was determined on top samples only. Dissolved-oxygen concentration at Bristol is nearly uniform in the top cross section. From Lehigh Avenue to Eddystone the oxygen concentration is more depleted on the Pennsylvania side of the River than on the New Jersey side, the difference averaging $0.7 \mathrm{ppm}$. At Marcus Hook the dissolved oxygen is approximately $1.0 \mathrm{ppm}$ lower on the Pennsylvania side.

On the twice-daily flood tide, salt water flows upstream, and the salinity at each sampling station increases. The maximum salinity occurs at high-water slack, the time at which the flood current reverses and becomes an ebb current. During the ebb tide the salty water is swept seaward by the downstream flow of fresher water, and the increase in fresh water causes the salinity at any sampling station to reach a minimum at low-water slack. Thus, the salinity at any location in the estuary each day goes through two maxima, not necessarily identical, and two minima, also not necessarily identical.

Onshore winds blow sea water shoreward and may raise the sea level at the south of Delaware Bay. This rise in sea level causes water to move upriver and salinity to increase in the lower estuary. Offshore winds may cause a decrease in sea level and a corresponding 
flow of water seaward throughout the river and estuary, thereby decreasing the salinity; however, when sea levels return to normal as the offshore winds subside, ocean water flows into the estuary replacing that which had been blown out. The end result is, therefore, saltier water in the estuary. The magnitude of these changes in salinity depends upon the force and direction of the wind and its duration.

The samples referred to in this report were taken at random times with respect to stage of tide, tidal range, and sea level. In the present sampling program specific conductivity, $\mathrm{pH}$, temperature, and dissolved oxygen are recorded continuously at several locations. As a result, there soon will be a more comprehensive knowledge of water-quality changes and of the precise times that they occur. This knowledge will help in evaluating the relative effects of such factors as sea level and fresh-water discharge.

\section{SUMMARY AND CONCLUSIONS}

That reach of the Delaware River from Bristol to Marcus Hook was sampled in detail once each month during the 14 years from August 1949 to the end of 1963 . This period embraces a range of fresh-water inflow conditions. The 50-year average discharge at Trenton is $11,830 \mathrm{cfs}$; the largest annual mean discharge in the 14-year period was 150 percent as large as the 50-year average, and the smallest annual mean discharge 60 percent as large. In general, the salinity of this reach of the river is influenced by the discharge. In the lower half of this reach, the concentration of dissolved solids can be estimated from the measured specific conductance (expressed in micromhos at $25^{\circ} \mathrm{C}$ ). For concentrations less than $200 \mathrm{ppm}$, the dissolved-solids concentration (in ppm) is approximately $16 \mathrm{ppm}$ plus 52 percent of the specific conductance. From 200 to $2,500 \mathrm{ppm}$, the dissolved-solids concentration is 60 percent of the specific conductance at $25^{\circ} \mathrm{C}$.

Although the annual mean discharge in 1952 was substantially larger than in any other year in the 1950-1963 period, this was not the year in which the river water contained the lowest concentration of dissolved solids. The river water was the least saline in 1958. The highest salinities were observed in 1954, 1957 and 1963. In each of these years the annual mean discharge was low, and the discharge for July, August, and September was also low. In 1953 and 1962 the July to September discharge was also low and the salinity high, but not as high as in 1954, 1957 and 1963.

The dissolved-solids concentration in the river water is lowest in the spring and highest in late summer and early autumn because the 
fresh-water discharge is greatest in March, April, and May and least in August, September, and October. For example, in March, April, and May the mean dissolved-solids concentration is $76 \mathrm{ppm}$ at Bristol, and $112 \mathrm{ppm}$ at Marcus Hook. In August and September the mean is $117 \mathrm{ppm}$ at Bristol and $804 \mathrm{ppm}$ at Marcus Hook. There is a greater variation of concentrations in the estuary at Marcus Hook than at Trenton, as a result of tidal action. The greatest dissolved-solids concentrations represented by these monthly samples were $160 \mathrm{ppm}$ at Bristol and 4,000 ppm at Marcus Hook.

The chloride concentration at Marcus Hook exceeded $100 \mathrm{ppm}$ 24 percent of the time and $10 \mathrm{ppm} 70$ percent of the time. At Benjamin Franklin Bridge, however, $100 \mathrm{ppm}$ chloride was exceeded only 2 percent of the time and $10 \mathrm{ppm}$ less than 40 percent of the time. At Chester, for a 31-year period, $250 \mathrm{ppm}$ chloride was exceeded 10 percent of the time, $60 \mathrm{ppm} 20$ percent of the time, and $15 \mathrm{ppm}$ 50 percent of the time.

The worst salinity invasions of the Delaware River were in 1949, 1953, 1954, 1957 and 1963. Significant increases in salinity were observed upstream from Lehigh Avenue, Philadelphia, Pa. In these 5 years the mean monthly discharge at Trenton for each month from July to October was less than 4,000 cfs; however, from July to September, 1962, the mean monthly discharge at Trenton was also less than 4,000 cfs each month, but the annual mean dissolved-solids concentration was not as great as in the 5 years referred to above.

Perhaps the major factor controlling the salinity of this reach of the estuary is the amount of fresh-water discharge into the estuary, especially in July, August, and September. For example, in those years in which the mean monthly discharge during July, August, and September exceeded 4,000 cfs at Trenton, the average annual dissolved-solids concentration of the river water at Benjamin Franklin Bridge, Philadelphia, was approximately $100 \mathrm{ppm}$ and varied little with change in discharge. For a mean monthly discharge of less than $4,000 \mathrm{cfs}$ in these 3 months, the dissolved-solids concentration at the Benjamin Franklin Bridge is greater than $100 \mathrm{ppm}$, and the concentration increases as the discharge becomes smaller. At Marcus Hook the annual mean dissolved-solids concentration is $180-300$ ppm and is relatively uninfluenced by variation in water discharge if the discharge rate at Trenton exceeds 5,000 cfs. At lower rates of flow the mean annual dissolved-solids concentration increases as the July-August-September discharge decreases. The principal source of fresh water is the Delaware River at Trenton, although some fresh water comes also from the Schuylkill River and other tributaries. A high rate of fresh-water discharge flushes out the 
river and opposes factors such as high sea level or onshore winds that favor the intrusion of salt water from the sea.

The median $\mathrm{pH}$ is 6.9 in the reach of the river from BristolBurlington Bridge to Torresdale, 6.6 from Lehigh Avenue to League Island, and 6.5 from Eddystone to Marcus Hook. Water temperatures range from $33^{\circ}$ to $86^{\circ} \mathrm{F}$, the median temperature being near $58^{\circ} \mathrm{F}$.

Dissolved oxygen is brought into the estuary with fresh water at Trenton, by tidal water in the lower estuary, by photosynthesis, and through the air-water interface. This oxygen is consumed in the oxidation of organic pollutants, a process which proceeds faster in the warm water of summer than in the cold water of the other seasons. Dissolved oxygen is at a lower concentration from May or June to October or November than during the winter months. As the water moves downstream, dissolved oxygen is consumed, and its concentration generally reaches a minimum near Wharton Street but increases slightly from there to Marcus Hook.

Owing to photosynthesis, the concentration of dissolved oxygen is greater in daylight than at night. Since the samples of water were always taken in daytime, the daily mean dissolved-oxygen concentrations were probably lower than those reported in the plots and tables. There is no evidence of a trend in dissolved-oxygen concentrations over the 14-year period, except that the lowest minimum concentrations were those of the July to November 1950 period in the reach of the river from Wharton Street to League Island. At Benjamin Franklin Bridge one-half of the samples were more than 55 percent saturated with dissolved oxygen, one-third less than 30 percent saturated.

When streamflow is high, sediment is picked up by the moving water and carried downstream, so that the sediment concentration increases from Bristol to Marcus Hook. Dredging also stirs up sediment and increases its concentration in the water at and downstream from the dredging area.

In the reach of river which includes the eight sampling stations, the water quality generally varied little in the cross section of the river. In most of this reach of river most of the time, the specific conductance of the water on the Pennsylvania side may be 5 percent greater than on the New Jersey side, and the dissolved-oxygen concentration about $0.7 \mathrm{ppm}$ less on the Pennsylvania side than on the New Jersey side, but temperature and $\mathrm{pH}$ are uniform. This situation may be the result of a greater concentration of industries and people on the Pennsylvania side with a consequent greater flow of wastes to the river. The analyses presented in this report, however, 
are of the cross section, including the channel and therefore are representative of most of the water flowing past each of the eight sampling stations.

The cross-sectional variation in water quality at Marcus Hook is somewhat greater than at the upstream stations. Here the bottom samples usually have specific conductances 5-10 percent greater than the top samples, and dissolved-oxygen concentrations are about 1.0 ppm lower on the Pennsylvania side. Most of the time the conductance of water on the Pennsylvania side is slightly greater than that of the water on the New Jersey side, but this situation is often reversed when the dissolved-solids concentration of the water is greater than $360 \mathrm{ppm}$.

At all stations the water quality varies twice daily with the ebb and flood of the tide. The salinity is greatest at time of slack water following high tide and lowest at the time of the slack water following low tide. The maxima and minima in dissolved-oxygen concentration often occur at slack water also, but whether the concentration of dissolved oxygen increases or decreases as the tide floods depends upon the dissolved-oxygen concentration in the reach of stream directly downstream from the sampling station.

This report summarizes the results of monthly sampling over a 14-year period. During most of this period, there were few instruments to continuously record water-quality data.

In 1955 the U.S. Geological Survey installed the first recording instrument in the estuary for continuously measuring and recording specific conductance, and in 1959 dissolved-oxygen and temperature recorders were installed. In 1964, in the reach of the estuary between Bristol and Marcus Hook, temperature was continuously recorded at or near four of these monthly sampling stations, specific conductance at three, dissolved oxygen at four, $\mathrm{pH}$ at one, and turbidity at one. In addition, tidal-flow volume is measured at one point (Palmyra, N.J.), and tide gages record water-level fluctuations at about a dozen locations in this reach (Miller, 1962). Hand sampling is still required to establish a relation between the cross section and the continuously recorded values to check on the accuracy of the instrument record and to collect samples for types of analyses which have not yet been adapted to recording instruments such as biochemical-oxygen demand. Obviously, in the future the greater frequency of measurement by automatic instruments will give more information about the range in water-quality characteristics and determine more precisely when variations occur.

Although a much more detailed description of water quality in this reach of the estuary will soon become available through the use of recording instruments, it is nevertheless useful now to summarize 
these monthly analyses for the period 1949-63. This period includes a range of conditions and exhibits the extent to which water-quality parameters varied with change in hydrologic and environmental conditions. This compendium of water-quality data is useful as an explicit statement of water quality during the 14-year period and is valuable for directing attention to water-quality problems, for selecting instrument sites, and for making comparative studies with the more detailed information which is already being obtained with the aid of recording instruments.

\section{SELECTED REFERENCES}

Cohen, Bernard, and McCarthy, L. T., Jr., 1962, Salinity of the Delaware River estuary: U.S. Geol. Survey Water-Supply Paper 1586-B, p. 47.

Durfor, C. N., and Anderson, P. W., 1963, Chemical quality of surface waters in Pennsylvania: U.S. Geol. Survey Water-Supply Paper 1619-W, p. 50.

Durfor, C. N., and Keighton, W. B., 1954, Chemical characteristics of Delaware River water Trenton, New Jersey, to Marcus Hook, Pennsylvania: U.S. Geol. Survey Water-Supply Paper 1262, p. 173 [1955].

Ketchum, B. H., 1951a, The exchanges of fresh and salt waters in tidal estuaries: Jour. of Marine Research, Sears Foundation, v. 10, no. 1, p. 18-38. 1951b, The flushing of tidal estuaries: Sewage and Industrial Wastes, v. 23, no. 2, p. 198-208.

McCarthy, L. T., Jr., and Keighton, W. B., 1964, Quality of Delaware River Water at Trenton, New Jersey: U.S. Geol. Survey Water-Supply Paper 1779-X.

Miller, E. G., 1962, Observations of tidal flow in the Delaware River: U.S. Geol. Survey Water-Supply Paper 1586-C, p. 8-26. 